
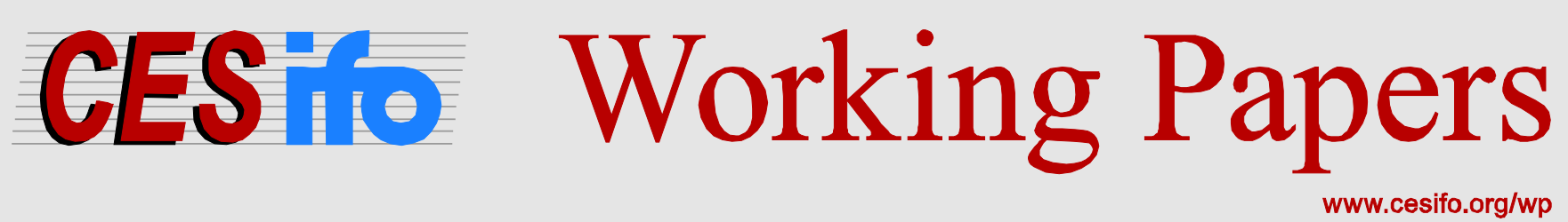

\title{
Engineering Growth: Innovative Capacity and Development in the Americas
}

\author{
William F. Maloney \\ Felipe Valencia Caicedo
}

CESIFO WORKING PAPER NO. 6339

CATEGORY 5: ECONOMICS OF EDUCATION

FEBRUARY 2017

An electronic version of the paper may be downloaded

- from the SSRN website:

- from the RePEc website:

- from the CESifo website:

WWW.SSRN.com

www.RePEc.org

www.CESifo-group.org/wp

ISSN 2364-1428

\section{CESifo}




\title{
Engineering Growth: Innovative Capacity and Development in the Americas
}

\begin{abstract}
This paper offers the first systematic historical evidence on the role of a central actor in modern growth theory - the engineer. It collects cross-country and state level data on the labor share of engineers for the Americas, and county level data on engineering and patenting for the US during the Second Industrial Revolution. These are robustly correlated with income today after controlling for literacy, other types of higher order human capital (e.g. lawyers, physicians), demand side factors, and after instrumenting engineering using the Land Grant Colleges program. A one standard deviation increase in engineers in 1880 accounts for a $16 \%$ increase in US county income today, and patenting capacity contributes another $10 \%$. We further show engineering density supported technological adoption and structural transformation across intermediate time periods. Our estimates help explain why countries with similar levels of income in 1900, but tenfold differences in engineers diverged in their growth trajectories over the next century. The results are supported by historical case studies from the US and Latin America.
\end{abstract}

JEL-Codes: O110, O300, N100, I230.

Keywords: innovative capacity, human capital, engineers, technology diffusion, patents, growth, structural transformation, development, history.

William F. Maloney*

Development Economics Research Group

\& EFI, The World Bank

USA - Washington, D.C. 20433

wmaloney@worldbank.org
Felipe Valencia Caicedo

Department of Economics \& Institute of

Macroeconomics and Econometrics

University of Bonn / Germany

valencia@uni-bonn.de

\section{*corresponding author}

January 28, 2017

We thank Ufuk Akcigit, David de la Croix, Leo Feler, Raquel Fernandez, Claudio Ferraz, Christian Fons-Rosen, Oded Galor, Steve Haber, Lakshmi Iyer, Ruixue Jia, David Mayer-Foulkes, Stelios Michalopoulos, Guy Michaels, Petra Moser, Aldo Musacchio, Giacomo Ponzetto, Luis Serven, Andrei Shleifer, Moritz Shularick, Enrico Spolaore, Uwe Sunde, Bulent Unel, Nico Voigtlnder, Hans-Joachim Voth, Fabian Waldinger, Leonard Wantchekon, David Weil, and Gavin Wright for helpful discussions. We are grateful to William Kerr for generously making available the patent data. We thank audiences at NBER SI 2016, NYU Stern, CESifo, FRESH 2013 (Valencia), London Business School, London School of Economics, SAEe 2013, Universit Catholique de Louvain, University of Copenhagen, University of Southern Denmark, and Williams College. Our thanks to Carlos Andrés Molina for superb research assistance. This paper was partly financed by the Knowledge for Change (KCP) trustfund. 
"You have all the elements, but you cannot make steel"

—Andrew Carnegie (1900) $)^{1}$

\section{Introduction}

Carnegie's taunt to the owners of the Birmingham Steel Company suggests the difficulties the American South faced in absorbing the knowledge required to establish dynamic industries and converge to the North. This remains the case in today's developing regions- a vast literature now puts barriers to technological adoption at the center of explanations of the distribution of income globally $\left.\right|^{2}$ Most recently Comin et al. (2008); Comin \& Ferrer (2013) argue that the diverging measured intensity of use of new technologies plausibly explains observed TFP differentials and can drive simulations that closely track the magnitudes of the Great Divergence of the last two centuries (e.g. Pritchett, 1997; Galor \& Weil, 2000; Galor, 2011).

That human capital is a critical ingredient in technology adoption also enjoys a substantial supporting literature $3^{3}$ There is no consensus, however, on what type of human capital is most important and, in particular, the role of the upper tails of the education distribution, including higher order technical skills. Modern growth theory (Romer, 1990), empirical studies of technological transfer and innovation, and historical accounts of the Industrial Revolution put the engineer and associated scientific institutions at the center of the growth process, especially during the Second Industrial Revolution (see, for example, Mokyr, 1998; Mokyr \& Voth, 2010), I Yet, despite recent empirical work rigorously documenting the importance of some of these factors 5 there is no systematic evidence on the historical prevalence of allegedly

\footnotetext{
${ }^{1}$ Cited in Wright (1986) p.171. Wright also documents similar difficulties in the textile and lumber industries.

${ }^{2}$ See also, Parente \& Prescott (1994); Eaton \& Kortum (1999, 2001); Galor \& Moav (2006); Caselli (2001); Comin \& Hobijn (2004); Keller (2004); Klenow \& Rodriguez-Clare (2005); Comin et al. (2010a); Comin \& Hobijn (2010); Comin et al. (2012).

${ }^{3}$ See, for example, Nelson \& Phelps (1966); Foster \& Rosenzweig (1996); Cohen \& Levinthal (1989); Benhabib \& Spiegel (1994); Basu \& Weil (1998); Temple \& Voth $\mid(1998) ;$ Howitt (2000); Abramovitz \& David (2001); Acemoglu \& Zilibotti|(2001); Franck \& Galor (2015); Krueger \& Lindahl (2001); Caselli|(2001); Jones (2002); Comin \& Hobijn (2004); Benhabib \& Spiegel (2005); Aghion et al. (2005); Howitt \& Mayer-Foulkes (2005); Aghion et al. (2009); Ciccone \& Papaioannou (2009); Goldin \& Katz (2009); Barro \& Lee (2015).

${ }^{4}$ See Gordon (2016) for a discussion of the centrality of this period to US and world growth.

5 Becker et al. 2 2011); Cantoni \& Yuchtman (2014); Cinnirella \& Streb (2013); Voigtländer \& Squicciarini (2014); Yuchtman (2014).
} 
the central actor in modern economic growth, or even the relative importance of the upper educational tails for growth and hence, their plausible importance to explaining the patterns of development that we see today.

In this paper we first make this very basic contribution. We establish the stylized facts surrounding the relative density (population share) of engineers during the second wave of the Industrial Revolution (circa 1900) at the national level for the Western Hemisphere and representative benchmark countries of Europe, and the same at the sub-national level for six countries in the Americas ${ }^{6}$ The engineering data collection is done in a systematic way drawing on graduation records, membership in professional societies, and census data. We see these estimates, first, as a measure of what they are: the stock of higher level scientifically oriented human capital available during the second wave of the Industrial Revolution. Second, because our national measures are based on graduates of domestic engineering schools, they also proxy for the universities and institutions that support them, and for which data are more elusive. $]^{7}$ Further, we are sympathetic to the use in Murphy et al. (1991) of engineering density as a proxy for "good entrepreneurship." In sum, we see it as a broad proxy for innovative capacity defined as the capacity to absorb new technologies from abroad and modify as necessary, as well as invent. We document the extraordinary variance in engineering density across countries of very similar income levels in 1900-for instance Argentina, Chile, Denmark, Sweden and the southern US- that correlates to their divergent income positions today (see Figure 1).

To more confidently establish the importance of engineers and innovative capacity as a determinant of income, we then develop a rich data set for the United States at the county level. The increased degrees of freedom allow controlling for an extensive set of geographical, growth related, and human capital variables that may be confounded with engineering. We instrument for possible endogeneity of engineering using the Morrill Land Grant Colleges program. This program had an important long run impact on establishing engineering train-

\footnotetext{
${ }^{6}$ We focus on this geographical area partly because of the centrality of the very disaggregated US analysis discussed below, and partly because, as noted by Engerman \& Sokoloff (1994); Acemoglu et al. (2001, 2002), the colonized New World provides an experiment yielding strikingly divergent development outcomes across states.

${ }^{7}$ See most recently Valero \& Van Reenen (2016) and Kantor \& Whalley (2014a) document the importance of universities and proximity to universities for growth.
} 
ing institutions, however this was not its initial intent and the location of the colleges was largely independent of demand considerations. We further incorporate geo-located patenting density as collected by Acemoglu et al. (2013). Patenting appears only partly explained by county engineering density. Hence, it appears that the two measures are capturing different things: patenting as capturing human capital or even institutions more dedicated to invention (Griliches, 1990; Sokoloff, 1988) while engineering may capture more adoptive activities (see Mokyr, 1992).

Both variables show an important and robust effect: a one standard deviation in engineering density in 1880 accounts for a 16\% rise in income today, and patenting capacity, though not instrumented, another 10\%. We document possible channels of influence on structural transformation through proxies for entrepreneurship and manufacturing activity fifty years later (1930). Further, we find very similar coefficients at the "state" level both for the US, suggesting migration issues among geographical units are not critical, and for a broader sample of countries in the hemisphere. Applying the well-estimated US county-level coefficient to the national level data, a one standard deviation in engineering density in 1900 accounts for a $36 \%$ difference in income today. We then use historical evidence to validate our ranking of innovative capacity and through case studies document the divergent development outcomes arising within industries and even identical goods (e.g. copper) in countries with the differing innovative capacities we quantify. Finally, we present some suggestive findings on the historical determinants of innovative capacity.

\section{Literature}

The economics literature has postulated several types of human capital and associated institutions that may be important to growth. Literacy, and accumulated years of schooling or enrollment have received the most attention (see Krueger \& Lindahl, 2001; Barro \& Lee, 2015), although as Vandenbussche et al. (2006); Aghion et al. (2009), the composition among levels of education matter as well depending on distance from the frontier. Goldin \& Katz (1999, 2011) focus particularly on secondary and tertiatry education. Other dimensions fig- 
ure importantly as well: Lucas (1993); Young (1993) and Foster \& Rosenzweig (1995), among others, stress the importance of accumulated "learning by doing"; Ben Zeev et al. (2015); de la Croix et al. (2015) focus on apprenticeship; and Baumol (1990) and Murphy et al. (1991) on entrepreneurial skills and orientation. In in his classic article on endogenous growth Romer (1990) highlights the research engineer and Mokyr (2005), the minority of "trained engineers, capable mechanics and dexterous craftsmen on whose shoulders the inventors could stand" (pg.16, see also Meisenzahl \& Mokyr (2011)). Rosenberg (2000) and Nelson (2005) stress the accumulated ability and scientific institutions to manage new ideas for innovation and invention and Cohen \& Levinthal (1989); Griffith et al. (2004), the capacity for research and development needed for technological transfer.

Several authors including Mokyr (1998), and Howitt \& Mayer-Foulkes (2005) stress that higher-order human capital and the institutions that generated and housed it may have had an even more determinant role at the dawn of the Second Industrial Revolution (circa 1870-1914), which saw an increased emphasis on more structured scientific inquiry such as laboratory-based R\&D.8 This scientifically oriented human capital, and a technologically savvy entrepreneurial class were necessary to tap into the expanding and increasingly sophisticated global stock of knowledge and convert it into local growth 99 The technological leap forward also meant an erosion in the efficacy of existing levels of human capital and innovative capacity relative to that needed to continue to adopt (see Howitt (2000); Aghion et al. (2005)). Building on this insight, Howitt \& Mayer-Foulkes (2005) argue for multiple equilibria in innovation where countries whose human capital evolved with the frontier at the time of the technological leap forward could innovate or adopt, but those whose frontier adjusted human capital did not keep up slipped to an equilibrium where even the adoption of technologies was difficult, and stagnation followed (see Annex I for a sketch of the model) ${ }^{10}$

\footnotetext{
$\sqrt[8]{\text { Rosenberg }(2000)}$ and Nelson (2005) stress the related institutions more generally as a central dynamic of industrialization.

${ }^{9}$ As numerous authors have stressed from Schumpeter (1934) to the present, technological progress without entrepreneurs to take it to market does not lead to growth (see Aghion \& Howitt, 1992, Baumol, 1990, 2010 , Glaeser, 2007, Glaeser et al., 2009, 2010, Braunerhjelm et al., 2010; Iyigun \& Owen, 1998, 1999). Over the longer term this reflects the accumulation of a specific kind of human capital, at the very least, suited to the evaluation and management of risk, but extending to skills for managing people, credit, and technologies which need to be learned.

${ }^{10}$ Also Gancia et al. (2008) for related discussion of convergence clubs resulting from education-technology complementarities.
} 
Iyigun \& Owen (1998, 1999) relatedly argue that if the the initial stock of both professional (scientific) and entrepreneurial human capital is too low, the return to accumulating human capital will be low and economies can find themselves in a development trap in the long run.

Empirically, documenting the impact of even very basic measures of human capital on growth or relative incomes has proved surprisingly complex since the seminal studies of Barro (1991) and Mankiw et al. (1992). Further, there have been relatively few efforts to systematically capture what kind of human capital matters, or even to document the stocks of different types of capital. Goldin \& Katz (2011); Goldin (1999); Goldin \& Katz (1999) have documented the evolution of secondary and tertiary education in the context of US growth. Judson (1998), Wolff \& Gittleman (1993), Self \& Grabowski (2004), Castelló-Climent \& Mukhopadhyay (2013) attempt to document whether tertiary education matters more or less than primary education. Closest to this work, Murphy et al. (1991) document that countries with a higher proportion of engineers grow faster relative to those with a higher proportion of law concentrators 11

Confirming the relevance of human capital becomes even harder when a longer historical perspective is taken. Cantoni \& Yuchtman (2014) show that areas closer to the first German universities around 1386 experienced increased economic activity. Campante \& Glaeser (2009) argue that the "lion's share" of the differences in long run income level between the cities of Buenos Aires and Chicago is human capital, but they lament that literacy remains the primary, albeit coarse, measure of it (see, for example, Mariscal \& Sokoloff (2000)). Voigtländer \& Squicciarini (2014) show that mid-18th century French cities with more subscriptions to the Encyclopdie, capturing higher order human capital, grew faster after the dawn of the Industrial Revolution. Becker et al. (2011) show basic education in Prussia in the 19th century to be associated with industrialization. Yuchtman (2014) shows that in

\footnotetext{
${ }^{11}$ For overviews see Krueger \& Lindahl (2001); Sianesi \& VanReenen (2003); Stevens \& Weale (2004) and Acemoglu \& Zilibotti (2001); Pritchett (2001); Easterly (2002); Benhabib \& Spiegel (1994). A recent literature has sought to explain the often small measured impact by incorporating measures of the quality of human capital (see, for example Hanushek \& Woessmann, 2007, Behrman \& Birdsall, 1983, Hanushek \& Woessmann, 2012). In a similar spirit to the present work, Hanushek et al. (2015) find that differences in human capital account for 20-35 percent of the current variation in per-capita GDP among US states. Hsieh et al. (2013) argue that the rise in higher level skills among particularly women and African Americans resulting from reduced barriers to occupational allocation raised US growth substantially since 1960.
} 
early 20th century China, engineers enjoyed massive wage premia over all other classes of higher education, and that modern Western education and engineers in particular were critical to China's ability to adopt Western technologies. Cinnirella \& Streb (2013) show that increases in the stock of human capital in 19th century Prussia not only improved workers productivity but also accelerated innovative activities which, in turn, evoked an additional rise in the productivity level ${ }^{12}$ Waldinger $(2012)$ shows that the dismissal of scientists in Nazi Germany led to a permanent decrease in growth while Moser et al. (2014) show that their immigration to the US substantially increased invention there.

To date, however, neither the historical prevalence of Romer's research engineers or Mokyr's engineers and mechanics, nor Rosenberg's and Nelson's systems of innovation have been quantified in a globally comparable form and, in particular during periods of intense technological change such as the Second Industrial Revolution. We seek to remedy this below as well as offer estimates of their importance to the growth process.

\section{Data}

\subsection{Measuring Engineering/Innovative Capacity}

Our primary measure of innovative capacity at the national level across all countries is the number of engineers with domestically emitted university degrees per 100,000 male workers. Unlike literacy data, which countries sometimes collect as part of the census, countries do not tabulate such information in a uniform fashion. Hence, we construct these series using three sources of data.

Engineering Graduates: To the degree possible, calculations are done with actual graduates of engineering colleges and universities within the country. Clearly, many engineers even in the US acquired valuable training on the ground, or may have had partial degrees from some type of technical program. However, such skills are difficult to capture with any degree of commonality across geographical units. As a more consistent metric across countries, we

\footnotetext{
${ }^{12}$ Similarly Braguinsky \& Hounshell (2015) note that engineers were the highest paid employees in in the flagship Japanese textile industry in the 1880 s and were critical for technology transfer in the dominant firm.
} 
take the number of degrees awarded. Though most countries also employed foreign engineers, we are interested in indigenous technical capacity and the institutional structure to generate it, so we focus on domestically trained engineers.13 Some nationals studied abroad, however the historical evidence from Argentina, Chile, Colombia and Mexico suggests the numbers are small and difficult to document. Since the working life of an engineer is roughly 40 years, we begin accumulating the stock in 1860, discounting the stock in each period by .983 as the rate of death/attrition in each year. In some cases, we have a long series of graduation records which make this procedure straightforward. In Bolivia, Denmark, Mexico, New York, Peru, Spain, Sweden, Venezuela, or Mexico, the flow of graduated engineers is available for the 1860-1900 period. We refer to Ahlström (1982)'s estimates for Germany and France, the frontier countries, which are allegedly generated in a virtually identical manner 14 In other cases, for instance, Argentina, Brazil, Chile, Colombia, Ecuador, and the US as a whole, the information is less complete and we bring other sources of data to bear to fill in the gaps in the series.

Membership in Engineering Societies: Data on membership in Engineering societies or official registries validate broad orders of magnitude of our generated stocks. In some cases, such as Brazil, registry with the government was required to be a practicing engineer. What is considered an engineer, however, is less clear and hence these measures are less definitionally tight. In other countries, such as Colombia or Argentina, membership in Engineering associations was not required so registration likely underestimates.

Census Data: Census data are also available in several countries. Census data have the advantage of being collected over time by several countries and across sub-national units. However, here, also, it is the individual respondent who is deciding whether he is an engineer or not with limited institutional confirmation, or detail on the actual level of education. This is reasonable for within country analysis but less reliable for cross-country comparisons ${ }^{15}$

\footnotetext{
${ }^{13}$ For Argentina we have data on both foreign and domestic engineers and including the former leaves the results unchanged. We also control for the number of foreigners in the auxiliary US regressions and find no impact on the results.

${ }^{14}$ In fact, he calculates the stock for France, Germany as well as Sweden for which we do have the raw underlying data and hence can verify that we are doing the calculations in a virtually identical fashion.

${ }^{15}$ As numerous local historians have noted (Serrano (1993) in Chile, Bazant de Saldaña (1993) in Mexico) and in the case for which we have the best information, the US, censuses are often substantially higher than
} 
Sub-national data derive from the Argentine census of 1895, Mexican National Census of 1895, Chilean Census of 1907, Colombian census of 1912, Venezuelan Census of 1926, and US Census of 1900. For the US county level data, we use the census of 1880 to generate measures of literacy, and density of engineers, lawyers and medical doctors. Annex II discusses how these three sources of data were employed for each country in detail.

Patenting: For the US, we also construct a measure of average patenting activity from 1890-1910 drawing on patents granted by the United States Patent and Trademark Office (USPTO) again, at the county level, provided by Acemoglu et al. (2013). This is likely to capture Mokyr's more structured scientific inquiry at the frontier that began to assume a central role in the Second Industrial Revolution in addition to its direct interpretation as new ideas. It does not appear primarily driven by engineers or the other human capital variables and hence we interpret it as capturing a distinct type of human capital (see Sokoloff, 1988; Mokyr, 1992), or alternatively as a measure of institutions that promote it. Comparable patent data is not available for the Latin American countries and hence the variable only enters in the county-level US analysis.

\subsection{Sub-national Income per Capita}

Income in 2005 PPP US Dollars is drawn from a highly disaggregated spatial data set on population, income and poverty constructed on the basis of national census data by the World Bank (2009) for the World Development Report on Reshaping Economic Geography. ${ }^{16}$ Modern county level US income in dollars is mean household income taken from the 2000 US Census.

As control variables we use: literacy, secondary schooling, higher level non-engineering human capital, railroads, mining, manufacturing output, population density in 1900, precolonial population density, slavery, US South dummy, foreigners, agricultural intensity, religion, and a set of geographic and weather controls including temperature, altitude, rainfall, agricultural suitability, river density, distance to coast and ruggedness. As intermediate his-

the actual graduates of engineering programs.

${ }^{16}$ For further detail see Maloney \& Valencia (2016). 
torical outcomes we look at various measures of technological progress and structural change, among them value added in manufacturing, horsepower per manufacturing establishment, and number of retail establishments in 1930. Annex II offers detail on the construction of these measures. Table 1 presents the summary statistics at the state level and Table 2 at the US county level.

\section{Historical Engineering Density as a Driver of Present Income Differences: National Data}

Figure 1 plots our measure of national engineering density against GDP per capita, both in $1900{ }^{17}$ The availability of data means that our effective sample going forward is restricted to the relatively larger countries depicted here. Several facts merit note.

First, there is substantial variance in the stock of engineers that is weakly related to income in 1900. The Northern United States with a density of 160 is the highest in our sample, roughly double the average for the country as a whole, 84, while the US South shows roughly a third of the engineering density of the North at 60. Lagging as it is, the American South is miles ahead of the Latin American countries who average under 20. What is most striking is that countries that we tend to associate with declining relative position across the previous century, especially Argentina and to a lesser degree Chile and Mexico, show densities below countries of very similar levels of income: Argentina and Chile had roughly the same level of income as the American South, Sweden and Denmark yet had roughly a third of its engineering capacity of the South, and a fifth of the Scandinavian countries (100). Even if the number of engineers were underestimated by a factor of two, the lag with the US and Scandinavia would still be dramatic. We argue that that natural resource rents, while elevating income, were not being deployed as they were in the US or Scandinavia to the development of innovative capacity that would prepare them for the next phase of industrialization. In

\footnotetext{
${ }^{17}$ Maddison does not tabulate a separate series for the American South, but Mitchener \& McLean (2003) estimates place the US South roughly $50 \%$ below the national average and New England $50 \%$ above. Imposing these differentials on Maddison's data, places the South roughly $15 \%$ higher than Spain and the North roughly triple. Clearly, issues can be taken with even Maddison's Herculean effort, however, the available alternatives do not suggest that the picture would change much. Prados de la Escosura (2000) PPP based estimates with the OECD correlate .89 with those of Maddison, and do not significantly change the level of Spain relative to the US, although they move Portugal up perhaps 40\%, now above Mexico but still $20 \%$ below Spain.
} 
the framework of Howitt \& Mayer-Foulkes (2005) we have countries with similar levels of Schumpeterian backwardness, but with radically different levels of absorptive capacity.

Second, the dominance of the US in the Western Hemisphere is clearly not being driven by some idiosyncratic US data issue that would exaggerate its density. The US average is broadly in the same league as Denmark and Sweden, and even the North is below the calcu-

lations by Ahlström (1982) for France (200) and Germany (250), the frontier countries of the era. Nor is some sort of idiosyncratic data issue driving the consistently low scores of Latin America. All cluster very near each other and the colonial mother countries.

\subsection{Aggregate National Correlations}

As a quick check, basic correlations suggest that these differences in engineering densities for 11 countries are indeed correlated with present income. Since we have population density and income variables at the subnational level, we run a simple regression as a panel and bootstrap the clustered SEs at the country level (the results also hold with simple OLS):

$$
Y_{2005, i j}=\alpha+2+\gamma_{E} E_{n g_{1900}}+\gamma_{p o p} P_{o p_{1900, i j}}+\gamma_{R} \operatorname{Rail}_{1900_{i}}+\beta_{L} \operatorname{Lit}_{1900, i}+\epsilon_{i j}
$$

where the variables are defined as above for country i and sub-national unit $\mathrm{j}$ : the dependent variable is income per capita today; the explanatory variables are Literacy, Engineering density in 1900, Railroad density in 1900, Population density in 1900, and a set of geographical controls. Table 3 shows that engineering in 1900 appears significantly in explaining today's income per capita despite controlling sequentially and then together for population density and railroad density. Were we to include Denmark and Sweden, whose density we have confidence in, not to mention France and Germany, the results would be even stronger. Columns 4 suggests that with few observations, it is impossible to separate the impact of engineering and literacy although in subsequent exercises we do. 


\subsection{Consistency with Historical Evidence}

Our engineering estimates are consistent with historical evidence. France and Germany were acknowledged leaders in the sciences and engineering. The relative positions of the two peripheral areas- Scandinavia vs. the Iberian peninsula correspond closely to the characterization of Landes (1998) and Bénabou et al. (2015a) of their respective attitudes towards science and the Enlightenment. Both Sweden and Denmark's institutions of higher technical learning date from the 1700s and Sweden's high density is consistent with the characterization by Sandberg (1979) of the country as the "Impoverished Sophisticate."18

The US started relatively early and energetically in the training of engineers. The first institution of engineering education emerged from the Revolutionary War at West Point, established in 1802, which trained engineers for both military and civilian purposes and by 1862 there were roughly a dozen engineering schools in the East, but there were also schools as far west as Michigan and south as Maryland 19 The passage of the Morrill Land Grant Act in 1862 led to an acceleration in the establishment of engineering programs, roughly sextupling the number in the decade after passage. ${ }^{20}$ The period also saw a deepening, as the profession in the U.S. diversified further into sub-branches.

The establishment of professional societies in Civil Engineering (1852), Mining (1871), Mechanical (1880) and Electrical (1884), testifies the the consolidation of a process of specialization and diversification. By 1890, a modern and world class engineering profession was

18 The overproduction of engineers led many to emigrate to the US and $19^{\text {th }}$ century Swedish engineers are credited with inventing the blowtorch, ball bearings, ship propellers, the safety match, the revolver, the machine gun, dynamite, and contributing to the development of bicycles, steam turbines, early calculators, telephony (Ericsson) among others. We control for foreign immigration in Annex A4

${ }^{19}$ Subsequently the American Literary, Scientific and Military Academy at Norwich, Vermont awarded its first Civil Engineering degrees in 1837, and Rensselaer School in New York, in 1835. The Polytechnic College of the State of Pennsylvania, founded in 1853 granted degrees in Mechanical Engineering in 1854, and Mining Engineering in 1857.

${ }^{20}$ The Act led to the establishment of the Columbia School of Mines in 1864, Worcester Polytechnic in 1868, Thayer School of Civil Engineering at Dartmouth College in 1867, Cornell University as well as new universities in Iowa, Nebraska, Ohio, and Indiana. It also gave impetus to the foundation and consolidation of engineering schools in the South. As early as 1838 the University of Tennessee was teaching courses in Civil Engineering, but in 1879 it began awarding doctorate degrees in Civil and Mining Engineering. Texas A\&M awarded its first degree in Civil Engineering in 1880, Virginia Tech in 1885 in Mining Engineering, and the University of Kentucky, although having an engineering program dating from 1869, graduated their first civil engineer in 1890. Auburn University in Alabama began its engineering program in 1872, and North Carolina State in 1887. 
firmly established in the US.

Canada's innovative capacity is higher than that suggested by the density numbers since it was part of the greater New England scientific community. The four principal Canadian Universities emitting graduates- McGill, University of Toronto, Ecole Polytechnique in Montreal, and Queen's University in Kingston Ontario- lay within a circle of 350 mile radius with Cornell University at its center, and that includes many of the principal US departments of the time 21

The data for Latin America are consistent with the observation by Safford $(1976)$ in his classic Ideal of the Practical that "Latin American societies in general, and the upper classes in particular, have been considered weak in those pursuits that North Americans consider practical, such as the assimilation, creation, and manipulation of technology and business enterprise in general" (p 3). Graham (1981) argues that Brazil, consistent with our estimates, lagged far behind the American South in every aspect of industrialization, transportation and agricultural technology (p. 634). A long literature has focused on Argentina's weakness in innovation effort in comparison to countries such as Australia and Canada seen as similarly endowed (see, for example Diaz Alejandro, 1985, Duncan \& Fogarty, 1986; Campante \& Glaeser, 2009). The determined efforts in both these countries to achieve widespread literacy in the prairies had no analogue in Latin America, nor did the extensive expansion in the form of experiment stations and technical assistance. As Annex II documents, the national scientific establishments and professional training of civil engineers appeared much later and on a smaller scale. As an example, perhaps the richest country in Latin America at the time, Argentina, began graduating engineers only in 1870, and Peru, one of the premier mining centers of the hemisphere, in 1880, roughly on the same time line as Alabama. General engineering associations were set up in many countries around the same time that, in the US, associations in individual sub-fields were established.

\footnotetext{
${ }^{21}$ Although the first graduates were in the 1870 s, substantial engineering courses were in place by the 1850 s. Further, the articulation of the different fields of engineering occurred later than in the US but not much. The development of, for instance, mechanical engineering as a separate course occurred about 20 years after in the US, and Electrical Engineering 10-15 years after.
} 


\section{Establishing the Importance of Engineering and Patent- ing Capacity: US County Level Data}

We construct engineering and patenting density data for 2380 US counties ${ }^{22}$ Table 4 presents the OLS estimates including the core controls for geography, economic activity and education which reduce the number of observations to 1905. All specifications have robust errors and are clustered at the state level and include both OLS and fixed effect estimators. We estimate:

$$
Y_{2000, i}=\alpha+\gamma_{E} \operatorname{Eng}_{1900, i}+\gamma_{P} P a t_{1900, i}+\mathbf{G e o}_{\mathbf{i}} \gamma_{\mathbf{G e}}+\mathbf{Y}_{\mathbf{1 9 0 0 , \mathbf { i }}} \gamma_{\mathbf{G r}}+\mathbf{H C}_{\mathbf{1 9 0 0 , \mathbf { i }}} \gamma_{\mathbf{H}}+\mu_{\text {state }}+\epsilon_{i}
$$

To be consistent with the other samples, we begin with an OLS specification of engineering density along with a vector of geographical controls. As we will use these estimates for inference out of the US sample, we standardize the data and coefficients capture impact of a one standard deviation change. In column 1, engineering emerges strongly significantly and of expected positive sign in the OLS specification. Temperature and distance from the coast both enter negatively and significantly. Column 2 replicates the specification but with the smaller sample limited by slavery and education and results in only minor change in significance and magnitude.

Column 3 then includes the set of income related controls that together work to reduce the correlation that may occur simply because denser, richer areas with more infrastructure and in particular manufacturing and railroads, may be correlated both with engineers in 1900 and also with income today through non-innovation related channels. We further include a measure of slavery as an institutional variable that may be correlated with low human capital but also provides other institutional channels to present income. Population density, our measure of lagged economic activity, and railroads enter positively and significantly and will remain so throughout the analysis. Slavery, which enters significantly and negatively with just geographical controls (not shown) loses significance. As a measure of agricultural activity, farms per capita never enter significantly.

\footnotetext{
${ }^{22} \mathrm{~A}$ small number of counties change their borders in the last century and we drop them.
} 
The next 3 columns seek to ensure that the engineering measure is not simply a proxy for human capital more generally. Column 4 includes literacy which enters positively and significantly and reduces the engineering coefficient by just over $10 \%$. Column 5 then includes a proxy for secondary education whose importance across the next century Goldin \& Katz (2011) and Goldin (1999) have stressed and which enters significantly and positively. Goldin \& Katz (1999) also discuss the importance of the expansion in higher education across the earlier 1890-1940 period and in Column 6 we include several variables to ensure that engineers is not picking up higher order human capital more generally: the share of individuals who report attending at least one year of college, the density of lawyers (see Murphy et al., 1991; Cantoni \& Yuchtman, 2014), and density of physicians. The first two enter significantly and positively. Finally, column 7 includes all the human capital variables together. Literacy and lawyers remain significant although now neither secondary education, the college proxy, nor physicians do. Either literacy or college attendance can eliminate secondary education suggesting that, at this point in history, it is broadly proxying for literacy, or perhaps college readiness. The same remains true in column 8 which controls for state fixed effects which effectively controls for more local unobservables.

The positive effect of lawyers may arise, as posited by Cantoni \& Yuchtman (2014) because in earlier periods they were critical to the establishment of institutions and economic rules of the game. If we divide the sample into that above and below the mean level of engineers, (Table A4) overall suggests higher density of lawyers overall may enhance the effect of engineers. ${ }^{23}$ The negative effect of lawyers found by Murphy et al. (1991) may arise because as institutions firmed up over time, lawyers become less important and more oriented toward unproductive activity. The now positive impact of slavery suggests that its earlier negative effect worked largely through the human capital channel.

In all cases, engineering retains its significance at the $1 \%$ level although losing perhaps $50 \%$ of its magnitude from the initial specification and, as expected, substantially smaller than the 11 observation cross country regression where we could control for few likely correlated variables. The relative robustness of engineering vs. secondary education suggests that

\footnotetext{
${ }^{23}$ We thank Ruixue Jia for this suggestion.
} 
a small well-educated technological class was, at this time, more important than broad based post-literacy skills. The consolidation of higher education in engineering occurred well before the major expansion of secondary education which Goldin \& Katz (2011); Goldin (1999) document rose from only $18 \%$ in 1910 to $71 \%$ in 1940. Across our period, the corresponding average for the country is $7 \%$ with a maximum of $26 \%$.

Table 5 next explores the interaction of the engineering term with patents. Annex Table A1 suggests that engineering density is significantly correlated with patenting, but it explains perhaps $5 \%$ of the variance in patenting across counties. Further, even with a complete specification including all measures of formal human capital, we explain $50 \%$ of the variance. This suggests that, as in Sokoloff (1988); Aghion et al. (2015); Bell et al. (2015); Mokyr (1992) there may be a particular entrepreneurial or inventive human capital not captured by our engineering term, or, perhaps, institutions that encourage it. Columns 1 and 2 of Table 5 repeat the last two full specifications but replace engineering density with patenting density as the innovation capacity measure. Patenting enters significantly at $1 \%$ again in all specifications and both remain significant at at least the $5 \%$ level with and without fixed effects. Columns 3 an 4 combine the two measures. Both coefficients decline 15-20\% in magnitude suggesting that one channel through which engineering density operates is through patenting (as suggested by Table A1) and that some of the effect of patenting is as a proxy for engineering density perhaps working through non-patenting channels. However, that each continues to enter very significantly and independently suggests that they are capturing different types of human capital or other factors: perhaps more technological adoption in engineering and inventive activity in patenting (See again Mokyr, 1992). We fully accept the argument of Moser (2013) that much innovation including patentable invention is done outside the patent system and hence such distinctions cannot be drawn too sharply. However, our results suggest that there is a particular type of human capital captured by patents not captured by our other measures 24

\footnotetext{
${ }^{24}$ Table A5 shows these results to be robust to percentage of foreigners and degree of religious affiliation as additional controls.
} 


\subsection{Instrumenting Engineering}

Though we have attempted to control for other channels through which our engineering measure may be correlated with present income besides the capacity to manage and generate new technologies, we further attempt to control for residual upward bias by instrumenting engineers. There may be additional bias in the opposite direction since the large share of counties reporting zero engineers is more likely to reflect measurement error, rather than that there was absolutely no capacity of any kind to adopt technologies.

In the spirit of Card (2001); Moretti (2004); Cantoni \& Yuchtman (2014); Toivanen \& Väänänen (2016), we also instrument engineering density using the log distance to the nearest Morrill Land Grant colleges and universities. ${ }^{25}$ This is likely to be a good instrument because the establishment of the Land Grant colleges was largely supply driven and uncorrelated with demand for engineering services arising potentially from other drivers of growth, yet its likely channel of influence is precisely through the supply of higher order technical human capital as we document below in the first stage table.

The Morrill Program was introduced in 1862 precisely to remedy the perceived shortfalls in technical assistance in agricultural and mechanical innovation in the abstract. Its motivation was driven by both democratic ideals of educating the working man, and by observation that the US had none of the agricultural and technical schools found in Europe (Nevins et al., 1962; Nienkamp, 2010). However, it was not demand driven. As Johnson (1981) argues, "On the contrary, a case could be made that the new colleges were created by reformers, not practitioners, and for an ideal, not for an established need. Reaching out to sons, and later daughters, of farmers and artisans, to indigent students, and to whomever the existing system passed by was a noble egalitarian ideal that remained just that-an ideal-for decades, with laborious progress toward its realization. Dormancy or decline in enrollments had actually set in, with surprising results in the new colleges [46, p. 486; 13, pp. 66-68]. When Ohio's Land-Grant college opened, its public predecessor, Miami University of Ohio, was forced to close its collegiate department for want of enrollment, to resume only a dozen

\footnotetext{
${ }^{25}$ See Aghion et al. (2009) for a strategy instrumenting education using political variables.
} 
years later $[26$, pp. 54, 56]." This under-subscription was extremely common in the early years and confirms the supply driven nature of the enterprise.

Further, early years saw struggles over definition of what form that education should take, and precarious finance suggesting little initial impulse from the private sector. Prior to the Civil War, the South had actively opposed the bill, fearing greater interference in matters such as universal primary education and only the withdrawal of the Confederate States from the US Congress allowed the bill to be passed. However, during Reconstruction, recognizing its technological lag, the South started privately institutes such as Georgia Tech, and actively embraced the Morrill Program. Hence, while public functionaries may have broadly felt that the structure of their economies would reward such investment (although the long absence of agricultural institutes suggest this is far from obvious), there is little evidence of organized industry lobbying, for example, that would suggest causality from industry demand for engineers to the establishment of these universities.

That said, the channel through which the Land Grant colleges is likely to affect growth is precisely through the generation of higher order technical human capital. Though, the promoters of the Morrill Program did not envisage it as fomenting engineering per se, it would would eventually finance the first engineering departments in the West, Midwest and Especially the South and would become a central driver in developing the higher order scientific and Engineering capacity of the country. Nienkamp (2010) in Land-Grant Colleges and American Engineers argues that, especially the Mid-Western schools "provided the foundation, both in training and number, for twentieth-century American professional engineering" and were critical in defining their identity and ushering in the modern scientific, laboratorybased approach to technical education. Nevins et al. (1962) argues that the Morrill Program "promoted the emergence of the most effective engineering schools on the globe." Goldin \& Katz (1999) note that while the majority of new universities of the time were privately started and Morrill cannot explain the expansion of higher education, it was central to engineering. As of 1908 they note that $60 \%$ of the nation's engineering students were found in public universities and the "geographical dispersion of engineering students came mainly from those enrolled in public schools" the rise of which they attribute to the Morrill Program 
(Goldin, 1999). Hence, the instrument is conceptually close to engineering density.

The first stage of a basic 2SLS (Table 6) reveals a strong positive correlation between engineering density and the Morrill proxy with very high Cragg-Donald F-tests (1\% level) and acceptable F-tests suggesting a strong instrument. Also of importance is that it is not correlated with the other measures of higher education- lawyers and physicians- in the period. In this sense, our interpretation differs with Moretti (2004) who uses a similar instrument for general higher education- we are likely capturing a channel through technical human capital, not generic higher education.

Further, as a placebo test, in the lower panel of Table 6 we run the same first stage regression but using as an instrument the second wave of the land grant colleges that occurred in 1890 or 10 years after our engineering density measure. If our earlier land grant instrument were simply picking up other persistent determinants of future income, we might expect this also to be the case with the 1890 wave. However, there is virtually no correlation between the two measures suggesting this is not the case.

Column 5 of Table 5 present the second stage results for the complete specification engineers enter again at the $1 \%$ level with a modest increase in value to .11 in the fixed effect specification. We do not present all previous specifications simply because, as with the OLS specifications, both engineering and patenting retain their significance and broad magnitudes throughout. Column 6 presents the results of a Buchinsky quantile regression model with selection into being a zero in the instrument stage. The results remain of similar order of magnitude and significance.

In the spirit of the next section that works at the "state" level, we replicate the exercise for the 1900 5\% subsample (again, which does not permit us to work at the county level), with the number of covariates reflecting the reduced degrees of freedom ${ }^{26}$ This higher level of aggregation allows for more mobility of labor among units of analysis as discussed by Aghion et al. (2009). Though, a high degree of mobility among counties could importantly reduce

\footnotetext{
${ }^{26}$ We thank Ufuk Akcigit for suggesting this exercise.
} 
the impact of our instrumented engineering variable, again, it does not seem to prevent the emergence of a very robust and significant coefficient. It also allows introducing a measure of mining activity which is available at the state, but not country level. Finally, the aggregation also offers an alternative approach to the zeros. The OLS and instrument estimates at .1 and .2 are significant are very close to the corresponding county level estimates respectively (Annex Tables A2 and A3).

Taken together, the US data suggests that innovative capacity, spanned by engineering and patenting density, has a strong and independent effect on future income levels. More specifically, running specification 6 in standard deviations suggests that a one standard deviation rise in engineering density leads to a $16 \%$ increase in income. Though not instrumented, patenting capacity leads to another 9.7\%. Hence higher level human capital plausibly accounts for large differences in state level income per capita. This does not imply the unimportance of lower level capital. A one standard deviation increase in literacy accounts for $51 \%$. A comparable increase in secondary schooling leads to only a $4.5 \%$ increase although, again, the high school movement began substantially later and the variance in 1880 is very

small. As a final back-of-the-envelope exercise, taking the coefficient from the well saturated US regressions and applying it to the international data in Figure 1, a one standard deviation rise in engineers in 1900 leads to an difference of 36\% in 2000 income. Clearly, we cannot put too much weight on this result, but again, it is suggestive that differing endowments of higher level scientific capital potentially contribute importantly to income differences.

\section{International Sub-national Engineering Data}

To see whether innovative capacity retains its predictive power beyond the US, we collect engineering data at the sub-national (state) level for Argentina, Chile, Colombia, Mexico, Venezuela and the US for which census data are available. To give a feel for the disparities, Figure 2 maps this data for the US and Mexico by decile of engineering density and strikingly confirms that the border divided worlds apart. In fact, the data likely understate the true difference since our calculated stocks in Figure 1 suggest substantial overstatement in the Mexican census data. Perhaps predictably, the advanced New England states and the heavily 
mining dependent and generally less populated Western states show the highest density while the emerging industrial centers of the Midwest are close behind. The South is concentrated in the lower ranks with South Carolina, Georgia, Arkansas and Alabama in the bottom decilesthe lowest density in the US. What is striking, however, is that the country that was the principal mining center of the Spanish empire is almost entirely concentrated in the first and second quintiles with Sonora and the two Baja Californias appearing in the third and fourth deciles. Taking out Mexico City and the border states, Mexico is almost uniformly below

even the American South in density of engineers. As we discuss next, despite four centuries of mining, it had not acquired a corpus of trained professionals in the field compared to relative newcomer, the American West. The other countries show similar patterns.

Table 7 employs the sub-national data and comes to similar conclusions to those previous. We estimate:

$$
Y_{2005, i j}=\alpha+\gamma_{E} E_{n g_{1900} i j}+\gamma_{p o p} P_{o p_{1900, i j}}+\gamma_{L} L i t_{1900, i j}+\mathbf{G e o}_{\mathbf{i}} \gamma_{\mathbf{G e}}+\mu_{i}+\epsilon_{i j}
$$

Engineering density enters persistently significantly and very close to the magnitude of the OLS estimates from the US county and state level samples. The finding of continued significance even after controlling for a measure of population density (column 2) is consistent with Comin et al. (2010a). In column 3, Literacy again enters positively and significantly and reduces the coefficient on engineering by 30\%, again, broadly consistent with the US results in both effect and overall magnitude of the final engineering coefficient. Though we cannot control for a more complete set of human capital measures, the county level exercises above suggest that, in fact, engineering is capturing innovation related human capital and not human capital accumulation more generally. In sum, the various estimations suggest that our county level US findings resonate internationally: both literacy and higher order human capital related to engineering and science and technology are important determinants of long run income.

\section{Possible Mechanisms of Influence}

Returning to the US county data, Table 8 presents suggestive evidence on the mechanisms through which innovative capacity affects present day by looking at five indicators measured 
50 years (1930 census) after our engineering measure or roughly half way through the period. Three are measures of industrialization: Manufacturing value added per capita and manufacturing establishments per capita capture structural transformation while horsepower per firm is more likely to capture increasing technological intensity of production. Second, following Murphy et al. (1991) association of engineering with entrepreneurship, or as a measure of industry related services, we employ as a proxy the number of retail stores per capita and value of net wholesale transactions per capita. In all cases, engineers emerge as statistically significant suggesting that innovative capacity was important to structural transformation and transition into both sectors.

Figure 4 further plots the coefficient of engineering density on manufacturing value added at 20 year intervals from 1860 to our midpoint of 1930, after which the censuses do not tabulate this information in a comparable fashion. We see that, as expected, the 1880 engineering density measure has an insignificant impact in 1860 alleviating concern about pre-sample trends. But from 1880 to the 1920, its coefficient grows steadily in magnitude and significance. The final 1940 point, while decreasing slightly, is statistically of the same magnitude ${ }^{27}$

As a final consideration and analogous to the discussion of lawyers above, Table A4 considers the interaction of engineers with agricultural activity (see, for instance Fiszbein (2015) and Kantor \& Whalley (2014b). Though our proxy for agricultural activity does not enter significantly as a determinant of long run income, it is still fair to ask if engineering capacity has a differential effect across more and less agricultural areas. When we split the sample (using the median number of farms per capita in 1880), the effect of engineers in both OLS and IV estimates on long-term income is concentrated in less agricultural areas. Though technical change in agriculture was likely to have been an important precursor for growth, taken together, engineers appear to have worked more through structural transformationdeveloping industry and perhaps associated services- as well as within manufacturing productivity. The next section employs case studies to further document the channels through which engineering density affected growth.

\footnotetext{
${ }^{27} 1930$ show the same pattern and we exclude it only for simplicity in the graph.
} 


\section{Support from History: Case Studies}

To flesh out our understanding of the mechanisms further, the next section presents several case studies from the American South and Latin America that document stunted long run within sector productivity growth and of frustrated structural transformation as a result of decient innovative capacity.

\subsection{The American South}

An extensive literature deals with Southern development and we present only a brief summary to draw the parallel with other cases. Wright (1986) casts much of his work explaining the US South's persistent lag exactly in terms of an innovative capacity framework. "The fundamental reason for [protracted lack of uptake of technologies] is that early industrialization is a matter of learning in the broadest sense of that term: in management, in technology, in marketing and certainly-though this is often underestimated- in learning on the part on the part of the labor force" (pp. 124-125). The South came relatively late to industrialization and lacked the indigenous technical capacity necessary for rapid catch up. The emblematic failure was of the Birmingham Steel industry referred to above. Central was that the low iron, high phosphorous nature of Alabama red hematite required substantial adaptations of technology to the Southern context which the local innovative capacity was not able to engineer. Nor was it able to develop Southern versions of new inventions in the paper and textile industries 28 In lumbering and iron making, as well, Southern producers of the 1920s were not only not innovative, they were using methods phased out decades earlier elsewhere. Wright (1986) further argues that "Having missed the formative phases of the 'American System', the South was lacking a machine-tools and capital-goods sector almost entirely and therefore was bypassed by the kind of adaptive, dynamic, path-breaking series of technological breakthroughs that made the 'American system' distinctive." (p. 124-125).

\subsection{Latin America vs. the US}

The potentially catastrophic impact of low engineering and innovative capacity is nowhere more in evidence than in the increasingly complex industry in which Latin America for cen-

\footnotetext{
${ }^{28}$ By way of contrast, Japan also initially imported technology and processes, but over time it generated distinctive technologies and, by the 1920s, was making its own textile machinery.
} 
turies had had a true comparative advantage, yet by the turn of the 20th century had lost: mining. As Figure 3 illustrates, Chile saw its world market share of copper fall from $40 \%$ to under 4 percent by 1911, and even as early as 1884 the Sociedad de Minera (Mining Association) wondered openly whether Chile's copper mines would survive at all (Collier \& Sater, 1996). Chilean historians date this technological slippage to the beginning of the nineteenth century, when "the work of mining was not very systematic" and the "receipt of industrial innovations [from abroad] was slow and without visible influence" (Villalobos et al., 1990, p. 95-96) ${ }^{29}$ Figure 3 captures this importing of technical ability, first in the 1870 s and 80s as Britain expanded in the nitrate and coal industry, and then after 1905 when major foreign copper companies took over the copper industry. The census data shows the density of foreign engineers increased from almost zero in 1870 to 80 in 1920, the last census which permitted disaggregating by nationality/profession, or roughly 4 times Chile's domestic density in 1900. These movements emerged concomitant with Chilean production reaching new highs and market share of an expanding global supply staging and important recovery. By 1918, American interests controlled 87\% of Chilean copper output (O’Brien, 1989).

In Mexico local entrepreneurs lost share in the industry they had dominated for centuries precisely due to lacking the capacity to master emerging technologies (Ruiz Larraguivel, 2004; Brading, 1971; Marichal, 1997). As Figure 2 shows, in Mexico, including even Zacatecas, San Luis de Potos, and Guanajuato, long centers of mining, density was at low levels compared to the newcomers in the US West. Around 1900, abandoned, underexploited and newly discovered mines fell to foreign hands that could bring new global technologies to bear and the US grew to control close to $80 \%$ of investments in the sector, much as occurred throughout the region 30

\footnotetext{
${ }^{29}$ Charles Lambert, a representative of a British mining company in La Serena who was trained in the cole Polytechnique in Paris, noted in 1819 the primitive mining practice, scarce knowledge of minerals, and inefficient smelting, all of which represented poor technique relative to that employed in Europe. See also Maloney (2002). One of Chile's most venerated historians, Francisco Encina noted that "from the point of view of capital and of technical and administrative aptitude, the copper industry is as demanding as the most complicated manufacturing industry" (Encina, 1972, p. 62). However, his studies revealed "an extraordinary economic ineptitude in the national population consequence of an education completely inadequate to meet the demands of contemporary life." (Idem, p. 17). Another prominent historian, Pinto Santa Cruz (1959) argued that Chileans failed to take advantage of opportunities for learning by doing and to evolve the innovative capacity required to confront the technological revolution in mining and hence became dependent on foreign firms.

${ }^{30}$ See Maloney (2015) for ownership details. As an example, the Guggenheim interests opened smelters in Monterrey (1892) and Aguascalientes (1894) purchased the largest Mexican Smelting and Refining company in
} 
The US eventual dominance of the Chilean copper and Mexican mining industries strikingly illustrates the road that could have been taken with the same homogenous product. Not only does Wright (1999) argue that US in the 19th century "parlayed its [natural] resourcebased industrial prosperity into a well-educated labor force, an increasingly sophisticated science-based technology, and world leadership in scientific research itself" (Wright, 1987, p. $665)$, but he uses precisely the US copper industry as an example of national learning and of innovation as a network phenomenon. In the post civil war period, the US became the foremost location for education in mining engineering and metallurgy. It was the revolution in metallurgy (e.g. the Bessemer process and the introduction of electrolysis on a commercial scale for the refining of copper), that propelled the copper industry during the last decades of the 19th century and laid the groundwork for much subsequent industrialization. The transference of these technologies by US firms to their mines and smelters in Chile and Mexico revolutionized the antiquated industries in both countries, dramatically increased production, and left them dominant in both ${ }^{31}$

Given this discussion and the sheer disparity of our innovative capacity numbers, the question emerges: if it was so hard for the American South to start competitive industries with its innovative capacity captured by 60 engineers per 100,000 individuals, how did Latin America's industry expand so quickly at the turn of the 20th century with an average of 10? The answer may lie in the Potemkin nature of much of Latin American industrialization that, as Wright argues for the American South, was dependent on imported capital goods and innovated little. For instance, for both the Brazilian iron and textile industries Birchal

1906, introduced modern methods of extracting and refining silver ores and in addition, started the production of lead and zinc mining (Bernstein, 1964, O'Brien, 1989). This phenomenon was visible throughout the continent. In Upper Peru (now Bolivia), the decline of silver production in some of the most famous mines, like those at Potosí, arose from the "failure to apply new mining techniques, heavy mortality among Indian laborers and the exhausting of previous rich veins" (Scobie, 1964, p. 59). In Ecuador, Hurtado (2007) argues that the discovery of new mineral deposits was hindered by a resistance to scientific methods. More generally, Di Tella (1985) argues that Argentina proved unable to move beyond a state of exploiting the pure rents of a frontier or extraction of mineral riches, and beyond the "collusive rents" offered by state-sanctioned or otherwise imposed monopolies to tap the "unlimited source of growth" found in exploiting the quasi-rents of innovation, as the US, Canada and Australia were able to do.

${ }^{31}$ The Guggenheim's El Teniente mine was the first in the world to apply the flotation process in concentrating low-grade ores. Mechanizing digging made Chuquicamata in the North the largest open pit mine and, again, a new concentration process was introduced using sulfuric acid and electrolytic precipitation to treat the mine's ore. From 1912-1926, copper production in Chile quintupled as a result, reversing a 25 year period of stagnation (O’Brien, 1989). 
(1999) notes "the existing informal and spontaneous technological innovative system was not developed enough to take the process of technological assimilation farther in the direction of a profound modification of existing foreign technologies, or to create a more complex indigenous technological alternative" (p. 183) and Haber (1997) notes for Mexico, "Since... capital goods industries now required well-developed scientific and engineering capabilities, Mexico had little choice but to import its capital equipment" (p. 18). The fact that Latin America evolved the highest levels of tariffs in the world prior to World War I - on average five times the rates in Europe- is arguably the result of the need to protect an industry erected on weak technological foundations 32

\section{Drivers of Innovative Capacity}

\subsection{The US}

Though a detailed examination of the factors determining innovative capacity at the turn of the century are beyond the scope of the paper, we briefly explore select potential drivers. Table 9 presents, first, the results for the US county patents for both engineers and patents. As a predetermined measure of agglomeration or economic activity, we introduce population density prior to colonization. We further introduce slavery as well as a Southern dummy (at the state level), plus geographical controls. Because of the zeros in engineers, we present both OLS (Column 1) as well as quantile estimates with selection to report a zero (Column 2). Column 3 reports OLS for patents and Column 4 the corresponding quantile regressions.

Somewhat strikingly, pre-colonial population enters strongly significantly and positively in all specifications with both engineers and patents. This offers a channel through which agglomerations and arguably economic activity persist over time (see Maloney \& Valencia (2016)). Slavery enters negatively and very significantly in all specifications confirming that reduced investment in higher level human capital is a channel through which slavery had a depressing impact on future incomes. The Southern dummy continues to enter significantly in all except the engineers selection model suggesting an impact beyond the set of factors

\footnotetext{
${ }^{32}$ See Coatsworth and Williamson and Clemson and Williamson, cited in Haber (2005). This supports Haber's theory that the standard view of protectionism stimulating industrialization is potentially backwards: An emerging, but technologically backward and uncompetitive industry demanded protection.
} 
associated with slavery. The geographical controls tell a mixed story. For engineers, only ruggedness enters positively while for patenting it enters negatively, perhaps reflecting the importance of engineers to mining, but not necessarily the likelihood that mining would generate patents. Temperature enters positively and significantly, and rainfall negatively in almost all specifications. For patents, altitude enters positively and significantly, and coastal distance negatively. Annex Table A6 further introduces a measure of church density per capita and density of foreigners. Both enter significantly although prevalence of religious institutions seems to deter patenting consistent with Bénabou et al. (2015ab). Our core results are not altered (see Annex Table A5).

\subsection{The Role of Colonial Heritage?}

The degrees of freedom available in the international data presented in Figure 1 are insufficient to generate comparable results with any degree of confidence. However, the remarkable similarity between the engineering density in Spain and Portugal and their colonial dependencies is consonant with the transmission of values and institutions related to educational and entrepreneurial capital formation from the Peninsular powers to their colonies, and with the striking parallels in development outcomes among them. Spain and Portugal, confronted with the Industrial Revolution in England, failed to develop a scientific vocation nor the complementary innovation promoting institutions essential to industrialization. Most recently in this spirit, Bénabou et al. (2015a) model the nexus of religion, scientific progress and coalitional politics and argue that Spain falls into a category of "Theocratic" regime with knowledge stagnation, extreme religiosity with no modernization effort, and high public spending on religious public goods. Mass education was not prioritized on either side of the Atlantic: in both mother countries literacy lagged even the black (often freed slave) population in the American South, and is of similar magnitude to that of the Latin American colonies 33 The Peninsular tradition of higher education was largely religiously based, focused on law, philosophy, and theology, proved resistant to attempts to introduce Enlightenment-

\footnotetext{
$\sqrt[33]{\text { Tortella }(1994)}$ notes that in 1900 Spain had a literacy rate of $44 \%$. This is slightly below that of Argentina (48\%) and blacks in the American South (49\%) (Collins \& Margo, 2006), and not dramatically ahead of Peru (38\%), Chile (37\%), Colombia (32\%), or Mexico (22\%). Portugal's low level of literacy, $22 \%$, is essentially identical to that of its colony Brazil (20\%).
} 
informed technical curricula ${ }^{34}$ and was exported to the colonies. As Safford continues (p. 3) "In the hands of the upper classes, Latin America's educational systems, at least in times past, have been dedicated to forming and maintaining the political elite and have been only mildly effective in furthering such economically practical aims as the broad diffusion of literacy and technical capacities." 35

Strikingly Spain's own development path shows the exact same issues of inability to manage new technologies and external dominance characterizing Latin America (Tortella Casares, 2000) suggesting a high degree of commonality in underlying factors. For example, the evolution of the Spanish mercury bmining industry precisely foreshadows the subsequent experience in Latin America discussed earlier 36

\section{Conclusion}

Much of the growth literature stresses differences in the capacity to generate, import, and apply new technologies as central to explaining relative growth performance. To date, however, there has been little data generated on the higher level human capital, in particular,

\footnotetext{
${ }^{34}$ In Portugal, the flagship university at Coimbra briefly established a more technical curriculum in 1759 under the Marquis of Pombal in the context of radical political, education and ecclesiastical reform to modernize the state and energize the economy. However, in 1777 there was a reaction against the reforms and the emphasis on natural science was abandoned and civil law regained its ancient prestige. Spain began training engineers seriously only in the 1850s, and by 1867 the country had only one functioning School of Industrial Engineers, located in Barcelona (Riera i Tuébols, 1993).

${ }^{35}$ Spanish America saw universities established from the moment of conquest, yet they were largely committed to the training of ministers to convert Indians, and lawyers to staff the empire (Benjamin, 1965). As (Will, 1957, p.17) documents for Chile, although it applies with greater generality "With the exception of the inadequate facilities provided by a few religious organizations, there did not exist before the middle of the eighteenth century an institution capable of furnishing the youth of the colony with the barest essentials of a secular education." The majority of the relatively few university educated members of the Brazilian elite at independence trained at Coimbra in the reinstated legal theological tradition (Carvalho, 1982). In Ecuador, (Hurtado, 2007, p. 115) argues that education quality even among the elite was poor and unfocused on practical elements. Again, he cites the American ambassador to Quito in the 1850s who found "convents instead of presses, barracks in place of schools." See comparable accounts in Will (1957) for Chile; Safford (1976) for Colombia; and Lopez Soria (2012) for Peru.

${ }^{30}$ Though Spanish mines were rich, and mercury had been worked for a thousand years, the lack of technical capacity and capital, and the slow growth of domestic metallurgical know how led Spanish entrepreneurs to work close to the surface and then sell out to foreigners once easy veins had been exhausted. In 1873, a UK and German led conglomerate purchased the mines on the Rio Tinto river in Andalucia, introduced new technologies, and from 1877-1891, became the world's largest producer of copper, contributing the to fall in Chile's global share in Figure 3. As (Tortella Casares, 2000, pp. 96, 213-215) summarizes: "extraction and processing constitute a classic example of the failure of Spanish entrepreneurs to confront the problems of developing an industrial sector with complex technology, intensive use of capital, [and] a fast-expanding horizon."
} 
the central figure of the engineer, and institutions required to make this possible and none to attempt to verify its impact on income differentials. This paper first generates national level engineering data for the Americas in 1900 that suggests that differences in innovative capacity plausibly can explain the disparate development trajectories of countries which, at the time, had very similar levels of income. To more conclusively establish the link, we employ county and state level data from the US and establish the robust explanatory power of engineering density and patenting, controlling for a variety of economic and geographic variables; measures of secondary and tertiary education that may be correlated, as well as attempting to control directly for possible endogeneity using the Morrill Land Grant Colleges. Finally, we show the persistence of the impact of engineering density in a multi-country panel working at the sub national "state" level. Hence, we find evidence of the importance of engineering density at the national, state and county levels. Further, we follow the impact of engineering density through several intermediate mechanisms across the next half century to establish an impact on technological intensification and structural change.

We then use historical evidence both to confirm the ranking of countries emerging from our engineering data, and to further document that precisely an inability to manage the new technologies emerging from the Second Industrial Revolution slowed growth in the US South and Latin American mining. The fact that the US was able to leverage this sector into a well-educated workforce and world leadership in scientific research, while Latin America lost the industry confirms the importance of innovative capacity, and the persistent effect of early high level human capital investments. Thus it also speaks to the issue of the sequencing of educational investment: the US had a well articulated engineering research and training establishment long before it began serious expansion of secondary education.

Finally, we conduct preliminary explorations of the determinants of innovative capacity. We show that for the US data, slavery had a negative impact on engineering density suggesting that human capital accumulation is a channel through which the institution negatively affected growth. Consistent with other recent work, religion enters negatively as well. In the international data, the similarity of engineering density in Spain and Portugal to that of Latin America, and the commonality of experiences with, for example, mining, suggests 
important inherited determinants of low capacity for technological absorption. Given the large impact we establish of higher order technical human capital and innovative capacity on income, further investigation of their determinants becomes central to the growth agenda. 


\section{References}

Abramovitz, M. \& David, P. A. (2001). Two centuries of American macroeconomic growth: from exploitation of resource abundance to knowledge-driven development. Stanford Institute for Economic Policy Research.

Acemoglu, D., Akcigit, U., Bloom, N., \& Kerr, W. R. (2013). Innovation, reallocation and growth. Technical report, National Bureau of Economic Research.

Acemoglu, D., Johnson, S., \& Robinson, J. A. (2001). The Colonial Origins of Comparative Development: An Empirical Investigation. American Economic Review, 91(5), 1369-1401.

Acemoglu, D., Johnson, S., \& Robinson, J. A. (2002). Reversal of Fortune: Geography and Institutions in The Making of The Modern World Income Distribution. The Quarterly Journal of Economics, 117(4), 1231-1294.

Acemoglu, D. \& Zilibotti, F. (2001). Productivity Differences. The Quarterly Journal of Economics, 116(2), 563-606.

Adkins, D. (1975). The great American degree machine: an economic analysis of the human resource output of higher education : a technical report sponsored by the Carnegie Commission on Higher Education. The Commission.

Aghion, P., Akcigit, U., Toivanen, O., \& Vaananen, A. (2015). Living the American Dream in Finland: The Social Mobility of Innovators. Technical report, mimeo Harvard.

Aghion, P., Boustan, L., Hoxby, C., \& Vandenbussche, J. (2009). The causal impact of education on economic growth: Evidence from the united states.

Aghion, P. \& Howitt, P. (1992). A Model of Growth Through Creative Destruction. Econometrica, 60(2), 323-51.

Aghion, P., Mayer-Foulkes, D., \& Howitt, P. (2005). The Effect of Financial Development on Convergence: Theory and Evidence. Quarterly Journal of Economics, 120, 173-222.

Ahlström, G. (1982). Engineers and Industrial Growth: Higher Technical Education and the Engineering Profession during the Nineteenth and Early Twentieth Centuries: France, Germany, Sweden and England. Croom Helm.

Ahlström, G. (1993). Technical Education, Engineering and Industrial Growth: Sweden in the Nineteenth and Early Twentieth Centuries. In R. Fox \& A. Guagnini (Eds.), Technology and Human Capital in Historical Perspective (pp. 115-142). Cambridge University Press. 
Akcigit, U., Kerr, W. R., \& Nicholas, T. (2013). The Mechanics of Endogenous Innovation and Growth: Evidence from Historical US Patents. Technical report, Working Paper.

Almada, M. \& Zalduendo, E. (1962). El Estudio de los recursos humanos de nivel universitario y técnico en la República Argentina.

Barro, R. J. (1991). Economic growth in a cross section of countries. The Quarterly Journal of Economics, 106(2), 407-443.

Barro, R. J. \& Lee, J.-W. (2015). Education Matters:Global Schooling Gains from the 19th to the 21st Century. Oxford University Press.

Basu, S. \& Weil, D. (1998). Appropriate Technology and Growth. The Quarterly Journal of Economics, 113(4), 1025-1054.

Baumol, W. J. (1990). Entrepreneurship: Productive, Unproductive, and Destructive. Journal of Political Economy, 98(5), 893-921.

Baumol, W. J. (2010). The Microtheory of Innovative Entrepreneurship. Princeton: Princeton University Press.

Bazant de Saldaña, M. (1993). Historia de la Educación Durante el Porfiriato. Serie Historia de la educación. Colegio de México, Centro de Estudios Históricos.

Becker, S. O., Hornung, E., \& Woessmann, L. (2011). Education and catch-up in the industrial revolution. American Economic Journal: Macroeconomics, 3(3), 92-126.

Behrman, J. \& Birdsall, N. (1983). The Quality of Schooling: Quantity Alone is Misleading. The American Economic Review, (pp. 928-946).

Bell, A., Chetty, R., Jaravel, X., Petkova, N., \& Van Reenen, J. (2015). The lifecycle of inventors. Technical report, mimeo Harvard.

Ben Zeev, N., Mokyr, J., \& Van der Beek, K. (2015). Flexible supply of apprenticeship in the british industrial revolution. Available at SSRN 2602133.

Bénabou, R., Ticchi, D., \& Vindigni, A. (2015a). Forbidden Fruits: The Political Economy of Science, Religion, and Growth. Technical report, National Bureau of Economic Research.

Bénabou, R., Ticchi, D., \& Vindigni, A. (2015b). Religion and innovation. The American Economic Review, 105(5), 346-351.

Benhabib, J. \& Spiegel, M. (1994). The Role of Human Capital in Economic Development Evidence from Aggregate Cross-country Data. Journal of Monetary economics, 34(2), $143-173$. 
Benhabib, J. \& Spiegel, M. (2005). Human Capital and Technology Diffusion. Handbook of economic growth, 1, 935-966.

Benjamin, H. R. (1965). Higher Education in the American Republics. McGraw-Hill, New York ; Sydney.

Bernstein, M. D. (1964). The Mexican Mining Industry, 1890-1950 : A Study of the Interaction of Politics, Economics, and Technology. State University of New York.

Birchal, S. d. O. (1999). Entrepreneurship in Nineteenth-century Brazil: the formation of a business environment. London.

Brading, D. A. (1971). Miners and Merchants in Bourbon México, 1763-1810. University Press, Cambridge.

Braguinsky, S. \& Hounshell, D. A. (2015). History and nanoeconomics in strategy research: Lessons from the meiji-era japanese cotton spinning industry. Strategic Management Journal.

Braunerhjelm, P., Acs, Z., Audretsch, D., \& Carlsson, B. (2010). The Missing Link: Knowledge Diffusion and Entrepreneurship in Endogenous Growth. Small Business Economics, $34(2), 105-125$.

Bruhn, M. \& Gallego, F. A. (2011). Good, Bad, and Ugly Colonial Activities : Studying Development Across the Americas. Review of Economics and Statistics.

Campante, F. \& Glaeser, E. L. (2009). Yet Another Tale of Two Cities: Buenos Aires and Chicago. NBER Working Papers 15104, National Bureau of Economic Research, Inc.

Cantoni, D. \& Yuchtman, N. (2014). Medieval universities, legal institutions, and the commercial revolution. The Quarterly Journal of Economics, 129(2), 823-887.

Card, D. (2001). Estimating the return to schooling: Progress on some persistent econometric problems. Econometrica, 69(5), 1127-1160.

Carvalho, J. M. d. (1982). Political Elites and State Building: The Case of NineteenthCentury Brazil. Comparative Studies in Society and History, 24(3), pp. 378-399.

Caselli, F. (2001). Cross-Country Technology Diffusion: The Case of Computers. The American Economic Review.

Castelló-Climent, A. \& Mukhopadhyay, A. (2013). Mass Education or a Minority Well Educated Elite in the Process of Growth: The Case of India. Journal of Development Economics. 
Centro Argentino de Ingenieros (1981). Historia de laIngeniería Argentina: Edición Especial Publicada. Centro Argentino de Ingenieros.

Ciccone, A. \& Papaioannou, E. (2009). Human capital, the structure of production, and growth. The Review of Economics and Statistics, 91(1), 66-82.

Cinnirella, F. \& Streb, J. (2013). The role of human capital and innovation in prussian economic development.

Cohen, W. \& Levinthal, D. (1989). Innovation and Learning: the Two Faces of R \& D. The economic journal, 99(397), 569-596.

Collier, S. \& Sater, W. F. (1996). A History of Chile, 1808-1994. Cambridge Universtiy Press. 1996.

Collins, W. J. \& Margo, R. A. (2006). Historical perspectives on racial differences in schooling in the united states. Handbook of the Economics of Education, 1, 107-154.

Comin, D., Easterly, W., \& Gong, E. (2010a). Was the Wealth of Nations Determined in 1000 BC? American Economic Journal. Macroeconomics, 2(3), 65-97.

Comin, D., Ferrer, M., \& Mestieri, M. (2010b). TheIntensiveMargin of Technology Adoption. Technical report, Harvard Business School.

Comin, D. \& Hobijn, B. (2004). Cross-Country Technology Adoption: Making the Theories Face the Facts. Journal of Monetary Economics, 51(1), 39-83.

Comin, D. \& Hobijn, B. (2010). An Exploration of Technology Diffusion. The American Economic Review, 100(5), 2031-59.

Comin, D., Hobijn, B., \& Rovito, E. (2008). Technology Uusage Lags. Journal of Economic Growth, 13(4), 237-256.

Comin, D. A., Dmitriev, M., \& Rossi-Hansberg, E. (2012). The Spatial Diffusion of Technology. Technical report, National Bureau of Economic Research.

Comin, D. A. \& Ferrer, M. M. (2013). If Technology Has Arrived Everywhere, Why Has Income Diverged? Technical report, National Bureau of Economic Research.

Contreras, M. E. (1993). The bolivian tin mining industry in the first half of the twentieth century. ISA Research Papers, (32).

de la Croix, D., Doepke, M., \& Mokyr, J. (2015). Clans, guilds, and markets: Apprenticeship institutions and growth in the pre-industrial economy.

Di Tella, G. (1985). Rents, Quasi Rents, Normal Profits and Growth: Argentina and the 
Areas of Recent Settlement. In Argentina, Australia, and Canada : studies in comparative development, 1870-1965. D.C.M. Platt and Guido di Tella.

Diaz Alejandro, C. F. (1985). Argentina, Australia and Brazil Before 1929. In Argentina, Australia and Canada: Studies in Comparative Develpment, 1870-1965. D.C.M Platt and Guido di Tella.

Diogo, M. (2007). Aprender a ser ingeniero: La enseñanza de la ingeniería en el portugal de los siglos xviii y xix. In A. Lafuente, A. Cardoso, \& T. Saraiva (Eds.), Maquinismo ibérico, Visiones hispanas. Doce Calles.

Duncan, T. \& Fogarty, J. (1986). Australia and Argentina: On Parallel Paths. The Hispanic American Historical Review, 66(2), pp. 353-355.

Easterly, W. (2002). The Elusive Quest for Growth: Economists'Adventures and Misadventures in the Tropics. MIT Press.

Eaton, J. \& Kortum, S. (1999). InternationalTechnology Diffusion: Theory and Measurement. International Economic Review, 40(3), 537-570.

Eaton, J. \& Kortum, S. (2001). Technology, Trade, and Growth: A Unified Framework. European Economic Review, 45(4), 742-755.

Edelstein, M. (2009). The production of engineers in new york colleges and universities, 1800-1950. In D. Eltis, F. Lewis, \& K. Sokoloff (Eds.), Human Capital and Institutions: A Long-Run View. Cambridge University Press.

Encina, F. A. (1972). Nuestra Inferioridad Económica: Sus Causas, Sus Consecuencias. Universitaria, Santiago de Chile, 3 edition.

Engerman, S. L. \& Sokoloff, K. L. (1994). Factor Endowments: Institutions, and Differential Paths of Growth Among New World Economies: A View from Economic Historians of the United States. Working Paper 66, National Bureau of Economic Research.

Facultad de Ingeniería (2011). Innovación, Excelencia Tradición: Facultad de Ingeniería 1861-2011. Universidad Nacional, Bogotá.

Fiszbein, M. (2015). Agricultural diversity, structural change and long-run development: Evidence from us counties.

Foster, A. D. \& Rosenzweig, M. R. (1995). Learning by Doing and Learning from Others: Human Capital and Technical Change in Agriculture. Journal of Political Economy, 103(6), 1176-1209. 
Foster, A. D. \& Rosenzweig, M. R. (1996). Technical Change and Human-Capital Returns and Investments: Evidence from the Green Revolution. The American Economic Review, 86(4), pp. 931-953.

Franck, R. \& Galor, O. (2015). The complementary between technology and human capital in the early phase of industrialization.

Galor, O. (2011). Unified Growth Theory. Princeton Univ Press.

Galor, O. \& Moav, O. (2006). Das human-kapital: A theory of the demise of the class structure. The Review of Economic Studies, 73(1), 85-117.

Galor, O. \& Weil, D. N. (2000). Population, technology, and growth: From malthusian stagnation to the demographic transition and beyond. American economic review, (pp. 806-828).

Gancia, G., Zilibotti, F., \& Acemoglu, D. (2008). Technology-Skill Complementarity and Competition Policy. Technical report.

Gennaioli, N., La Porta, R., Lopez-de Silanes, F., \& Shleifer, A. (2013). Human Capital and Regional Development. The Quarterly Journal of Economics, 105, 164.

Glaeser, E. L. (2007). Entrepreneurship and the City. NBER Working Papers 13551, National Bureau of Economic Research, Inc.

Glaeser, E. L., Kerr, W., \& Ponzetto, G. A. (2010). Clusters of Entrepreneurship. Journal of Urban Economics, 67(1), 150-168.

Glaeser, E. L., Rosenthal, S. S., \& Strange, W. C. (2009). Urban Economics and Entrepreneurship. NBER Working Papers 15536, National Bureau of Economic Research, Inc.

Goldin, C. (1999). A brief history of education in the united states.

Goldin, C. \& Katz, L. (1999). The shaping of higher education: The formative years in the united states, 1890 to 1940. Journal of Economic Perspectives, 13(1), 36-61.

Goldin, C. \& Katz, L. F. (2009). The Race between Education and Technology. Cambridge, MA: Belknap of the Harvard U.

Goldin, C. \& Katz, L. F. (2011). Mass secondary schooling and the state: the role of state compulsion in the high school movement. In Understanding Long-Run Economic Growth: Geography, Institutions, and the Knowledge Economy (pp. 275-310). University of Chicago Press. 
Gordon, R. J. (2016). The Rise and Fall of American Growth: The US Standard of Living since the Civil War. Princeton University Press.

Graham, R. (1981). Slavery and Economic Development: Brazil and the United States South in the Nineteenth Century. Comparative Studies in Society and History. Cambridge University Press.

Griffith, R., Redding, S., \& Reenen, J. (2004). Mapping the Two Faces of R\&D: Productivity Growth in a Panel of OECD Industries. Review of Economics and Statistics, 86(4), 883895.

Griliches, Z. (1990). Patent statistics as economic indicators: A survey. Journal of Economic Literature, (pp. 1661-1707).

Haber, S. (1997). Financial Markets and Industrial Developoment: A Comparative Study of Government Regulation, Financial Innovation and Industrial Structure in Brazil and Mexico, 1840-1930. Stanford, CA:Stanford University Press.

Haber, S. (2005). Development Strategy or Endogenous Process? The Industrialization of Latin Americ. Technical report.

Hanushek, E. \& Woessmann, L. (2007). The Role of Education Quality for Economic Growth. World Bank Policy Research Working Paper, (4122).

Hanushek, E. \& Woessmann, L. (2012). Schooling, Educational Achievement, and the Latin American Growth Puzzle. Journal of Development Economics, 99(2), 497-512.

Hanushek, E. A., Ruhose, J., \& Woessmann, L. (2015). Human Capital Quality and Aggregate Income Differences: Development Accounting for U.S. States. NBER Working Papers 21295, National Bureau of Economic Research, Inc.

Harnow, H. (1997). The Role of the Engineer in Danish Modernisation, 1850-1920. Scandinavian Economic History Review, 45(3), 224-243.

Howitt, P. (2000). Endogenous Growth and Cross-country Income Differences. American Economic Review, (pp. 829-846).

Howitt, P. \& Mayer-Foulkes, D. (2005). R\&D, Implementation, and Stagnation: A Schumpeterian Theory of Convergence Clubs. Journal of Money, Credit and Banking, 37(1), $147-77$.

Hsieh, C.-T., Hurst, E., Jones, C. I., \& Klenow, P. J. (2013). The allocation of talent and us economic growth. Technical report, National Bureau of Economic Research. 
Hurtado, O. (2007). Las Costumbres de los Ecuatorianos. Quito: Editorial Ecuador FTB.

ICC (1899). Annual Report of the Interstate Commerce Commission. United States Interstate Commerce Commission.

Iyigun, M. F. \& Owen, A. L. (1998). Risk, entrepreneurship, and human-capital accumulation. American Economic Review, (pp. 454-457).

Iyigun, M. F. \& Owen, A. L. (1999). Entrepreneurs, professionals, and growth. Journal of Economic Growth, 4(2), 213-232.

Johnson, E. L. (1981). Misconceptions about the early land-grant colleges. The Journal of Higher Education, (pp. 333-351).

Jones, C. I. (2002). Sources of us economic growth in a world of ideas. American Economic Review, (pp. 220-239).

Judson, R. (1998). Economic Growth and Investment in Education: How Allocation Matters. Journal of Economic Growth, 3(4), 337-359.

Kantor, S. \& Whalley, A. (2014a). Knowledge spillovers from research universities: evidence from endowment value shocks. Review of Economics and Statistics, 96(1), 171-188.

Kantor, S. \& Whalley, A. (2014b). Research proximity and productivity: long-term evidence from agriculture.

Keller, W. (2004). International Technology Diffusion. Journal of Economic Literature, $42(3), 752-782$.

Klenow, P. J. \& Rodriguez-Clare, A. (2005). Externalities and growth. Handbook of economic growth, 1, 817-861.

Krueger, A. B. \& Lindahl, M. (2001). Education for growth: Why and for whom? Journal of Economic Literature, 39, 1101-1136.

Landes, D. S. (1998). The Wealth and Poverty of Nations : Why Some are so Rich and Some so Poor. W.W. Norton, New York, 1 edition.

López, C., Carreras, A., Tafunell, X., \& Fundación, B. F. (2005). Estadísticas históricas de España: Siglos XIX-XX. Fundación BBVA.

Lopez Soria, I. (2012). Historia de la Universidad Nacional de Ingeniería, los aos Fundamentales, 1876-1909. Vol. 1. Lima: Universidad Nacional de Ingeniería, Proyecto Historia UNI.

Lucas, R. E. (1993). Making a Miracle. Econometrica, 61(2), 251-72. 
Maloney, W. F. (2002). Missed Opportunities - Innovation and Resource-Based Growth in Latin America. Policy Research Working Paper Series 2935, The World Bank.

Maloney, W. F. (2015). Techno-literate Entrepreneurship and Development in Latin America. World Bank Mimeo.

Maloney, W. F. \& Valencia, F. (2016). The Persistence of (Subnational) Fortune: Geography, Agglomeration, and Institutions in the New World. Economic Journal.

Mankiw, N. G., Romer, D., \& Weil, D. N. (1992). A Contribution to theEempirics of Economic Growth. The Quarterly Journal of Economics, 107(2), 407-437.

Mann, C. (1918). A study of engineering education: prepared for the Joint committee on engineering education of the national engineering societies. Bulletin (Carnegie Foundation for the Advancement of Teaching). Merrymount Press.

Marichal, C. (1997). Avances Recientes en la Historia de las Grandes Empresas y su Importancia para la Historia Económica de México. In C. Marichal \& M. Cerutti (Eds.), Historia de las grandes empresas en México, 1850-1930. Universidad Autónoma de Nuevo León - Fondo de Cultura Económica.

Mariscal, E. \& Sokoloff, K. (2000). Schooling, Suffrage and the Persistence of Inequality in the Americas, 1800-1945. In Political Institutions and Economic Growth in Latin America: Essays in Policy, History, and Political Economy, ed. Stephen Haber. Stanford, CA: Hoover Institution Press.

McInnis, M. (2004). Engineering Expertise and the Canadian Exploitation of the Technology of the Second Industrial Revolution. In J. Ljungberg \& J.-P. Smits (Eds.), Technology and Human Capital in Historical Perspective (pp. 49-78). Palgrave Macmillan.

Meisenzahl, R. \& Mokyr, J. (2011). The Rate and Direction of Invention in the British Industrial Revolution: Incentives and Institutions. Working Paper 16993, National Bureau of Economic Research.

Mendez, N. (2013). Historia de la Tecnología en Venezuela. Universidad Central de Venezuela.

Mitchener, K. J. \& McLean, I. W. (2003). The Productivity of US States since 1880. Journal of Economic Growth, 8(1), 73-114.

Mokyr, J. (1992). The lever of riches: Technological creativity and economic progress. Oxford University Press. 
Mokyr, J. (1998). The Second Industrial Revolution, 1870-1914. Northwestern University Manuscript. Evason, 1st edition.

Mokyr, J. (2005). The intellectual origins of modern economic growth. In A. Quadrio Curzio \& M. Fortis (Eds.), Research and Technological Innovation (pp. 17-80). Physica-Verlag HD.

Mokyr, J. \& Voth, H.-J. (2010). Understanding growth in europe, 1700-1870: theory and evidence. The Cambridge economic history of modern Europe, 1, 7-42.

Moretti, E. (2004). Estimating the Social Return to Higher Education: Evidence from Longitudinal and Repeated Cross-Sectional Data.

Moser, P. (2013). Patents and innovation: evidence from economic history. The Journal of Economic Perspectives, (pp. 23-44).

Moser, P., Voena, A., \& Waldinger, F. (2014). German jewish migrs and us invention. American Economic Review, 104(10), 3222-55.

Murphy, K. M., Shleifer, A., \& Vishny, R. W. (1991). The allocation of talent: Implications for growth. The Quarterly Journal of Economics, 106(2).

Nelson, R. R. (2005). Technology, Institutions, and Economic Growth. Harvard University Press, Cambridge, Mass.

Nelson, R. R. \& Phelps, E. S. (1966). Investment in humans, technological diffusion, and economic growth. The American Economic Review, (pp. 69-75).

Nevins, A. et al. (1962). The state universities and democracy. University of Illinois Press Urbana.

Nienkamp, P. (2010). Land-grant colleges and american engineers: Redefining professional and vocational engineering education in the american midwest, 1862-1917. American Educational History Journal, 37(1/2), 313.

Núñez, J. (2005). Signed with an x: Methodology and data sources for analyzing the evolution of literacy in latin america and the caribbean, 1900-1950. Latin American Research Review, 40(2), pp. 117-135.

Nunn, N. (2008). Slavery, Inequality, and Economic Development in the Americas: An Examination of the Engerman-Sokoloff Hypothesis. In E. Helpman (Ed.), Institutions and Economic Performance (pp. 148-180). Harvard University Press. 
Nunn, N. \& Puga, D. (2012). Ruggedness: The Blessing of Bad Geography in Africa. Review of Economics and Statistics, 94(1), 20-36.

O'Brien, T. (1989). Rich beyond the dreams of avarice: the guggenheims in chile. Business History Review, 63(1), 122-159.

Pachón, A. \& Ramírez, M. T. (2006). La Infraestructura de Transporte en Colombia Durante el Siglo XX. Bogotá : Fondo de Cultura Económica.

Parente, S. L. \& Prescott, E. C. (1994). Barriers to Technology Adoption and Development. Journal of political Economy, (pp. 298-321).

Pinto Santa Cruz, A. (1959). Chile, un Caso de Desarrollo Frustrado. Santiago : Universitaria, 1959.

Poveda Ramos, G. (1993). Historia Social de las Ciencias en Colombia: Ingeniería e historia de las técnicas, Vol. IV y V. Colciencias.

Prados de la Escosura, L. (2000). International Comparisons of Real Product, 1820-1990: An Alternative Data Set. Explorations in Economic History, 37(1), 1-41.

Pritchett, L. (1997). Divergence, Big Time. Journal of Economic Perspectives, 11(3), 3-17.

Pritchett, L. (2001). Where Has All the Education Gone? The World Bank Economic Review, 15(3), 367-391.

Riera i Tuébols, S. (1993). Industrialization and Technical Education in Spain, 1850-1914. Cambridge University Press.

Romer, P. M. (1990). Endogenous technological change. Journal of Political Economy, 98(5 pt 2).

Rosenberg, N. (2000). Schumpeter and the Endogeneity of Technology : Some American Perspectives. Routledge, London.

Ruiz Larraguivel, E. (2004). Los Ingenieros en la Industria Manufacturera. Formación, Profesión y Actividad Laboral. CESU-Plaza y Valdes.

Safford, F. (1976). The Ideal of the Practical : Colombia's Struggle to Form a Technical Elite. University of Texas Press, Austin.

Sandberg, L. G. (1979). The Case of theIimpoverished Sophisticate: Human Capital and Swedish Economic Growth before World War i. Journal of Economic History, 39(1), 225-241. 
Santa-Maria Alvarez, P. (1994). Origen, Desarrollo y Realizacion de la Escuela de Minas de Medellín. Ediciones Dike LTDE.

Schumpeter (1934). The Theory of Economic Development. (trans R. Opie). Boston: Harvard University Press.

Scobie, J. R. (1964). Argentina: A City and a Nation. Oxford University Press, New York.

Self, S. \& Grabowski, R. (2004). Does education at all levels cause growth? india, a case study. Economics of Education Review, 23(1), 47 - 55.

Serrano, S. (1993). Universidad Y Nacion: Colección Imagen de Chile. Editorial Universitaria.

Sianesi, B. \& VanReenen, J. (2003). The Returns to Education: Macroeconomics. Journal of economic surveys, 17(2), 157-200.

Sokoloff, K. L. (1988). Inventive activity in early industrial america: evidence from patent records, 1790-1846. The Journal of Economic History, 48(04), 813-850.

Stevens, P. \& Weale, M. (2004). 4 Education and Economic Growth. International handbook on the economics of education, 1830(1850), 164.

Telles, P. C. d. S. (1994). História da Engenharia no Brasil, Séculos XVI a XIX. Clavero, Rio de Janeiro.

Temple, J. \& Voth, H.-J. (1998). Human Capital, Equipment Investment, and Industrialization. European Economic Review, 42(7), 1343-1362.

Thorp, R. (1998). Progreso, Pobreza y Exclusión. Una Historia Económica de América Latina en el siglo XX. Washington D.C. BID- Unián Europea.

Toivanen, O. \& Väänänen, L. (2016). Education and invention. Review of Economics and Statistics, 98(2), 382-396.

Tortella, G. (1994). Patterns of Economic Retardation and Recovery in SouthWesternEurope in the Nineteenth and Twentieth Centuries. The Economic History Review, 47(1), pp. 1-21.

Tortella Casares, G. (2000). The Development of Modern Spain : An Economic History of the Nineteenth and Twentieth Centuries. Harvard University Press, Cambridge, Mass. :.

Valero, A. \& Van Reenen, J. (2016). The economic impact of universities: Evidence from across the globe. Technical report, National Bureau of Economic Research. 
Vandenbussche, J., Aghion, P., \& Meghir, C. (2006). Growth, distance to frontier and composition of human capital. Journal of Economic Growth, 11(2), 97-127.

Villalobos, S. R., , \& Beltrán, L. (1990). Historia de la Ingeniería en Chile. Hachette. Santiago.

Voigtländer, N. \& Squicciarini, M. (2014). Knowledge elites, enlightenment, and industrialisation. NBER.

Waldinger, F. (2012). Bombs, brains, and science.

Will, R. M. (1957). Some Aspects of the Development of Economic Thought in Chile (ca. 1775-1878). Technical report.

Wolff, E. \& Gittleman, M. (1993). The Role of Education in Productivity Convergence: Does Higher Education Matter? Contributions to Economic Analysis, 214, 147-147.

Wright, G. (1986). Old South, New South : Revolutions in the Southern Economy since the Civil War. Basic Books, New York.

Wright, G. (1987). The Economic Revolution in the American South. Journal of Economic Perspectives, 1(1), 161-78.

Wright, G. (1999). Can a nation learn? american technology as a network phenomenon. In Learning by doing in markets, firms, and countries (pp. 295-332). University Of Chicago Press.

Young, A. (1993). Invention and Bounded Learning by Doing. Journal of political economy, (pp. 443-472).

Yuchtman, N. (2014). Teaching to the tests: An economic analysis of traditional and modern education in late imperial and republican china. 


\section{A Appendices}

\section{A.1 Annex I: Modeling micro economics of technological adoption}

Numerous models exist for modeling the micro economics of adoption. Comin et al. (2010b); Comin \& Hobijn (2010); Comin et al. (2010a) for instance are closely aligned with the opening stylized facts about divergence at the intensive margin. Human capital shortfalls are embedded in a scalar that reflects barriers to adoption for the agent that adapts the technology to the idiosyncrasies of the country or for individual producers that find a profitable use for the technology. Howitt \& Mayer-Foulkes (2005) further unpack this parameter and investigate the effects that introducing a new technology of scientific inquiry, such as happened in the Second Industrial Revolution, can have in generating convergence clubs of advancing and lagging countries or regions. To briefly sketch their argument, the probability that an entrepreneur innovates is

$$
\mu_{t}=\lambda S_{t}^{\eta} z_{t}^{1-\eta} / \bar{A}_{t+1}
$$

where $\lambda$ represents the productivity of the innovation technology; $S_{t}$ the skill level of the entrepreneur broadly construed; $z_{t}$ the quantity of material inputs to the innovation process; and $\eta$ the Cobb-Douglas exponent in the innovation technology. As in Howitt (2000); Aghion et al. (2005), the division by $\bar{A}_{t+1}$ represents a crucial "fishing out" effect where the more advanced the technological frontier, the more difficult it is to innovate. In turn $S_{t}=\xi A_{t}$ where $\xi$ is the "effective education time," the product of schooling years and quality, and the multiplication by the local level of technological advance reflects an externality that in more advanced countries, teachers will be better versed in modern techniques, classrooms, curricula etc. are up to date and this will lead to more educational output per unit of effective education time.

$$
\mu_{t}=\frac{\mu \frac{A_{t}}{A_{t}}}{1+g}
$$

which states that $\mu_{t}$, the innovation rate, is function of overall competitiveness $\mu$ (which is in turn a function of policy distortion, incentives to innovate, overall profits, the incentive to save, and education.) The "normalized productivity", $A_{t} / \bar{A}_{t}$ captures increasing absorptive 
capacity with proximity to the frontier arising from the fishing out and education externalities. Finally, the denominator $(1+\mathrm{g})$ captures the growth rate of the frontier and reflects that local skills are proportional to productivity this period, whereas the skill level required to innovate depends on the global frontier next period. Hence, the faster the growth of the frontier, the larger the effort necessary to maintain a constant innovation rate ${ }^{37}$

For our purposes, there are two key results. First, as the global technology frontier advances and becomes more complex, a country needs to increase its skill levels to prevent the erosion of its absorptive capacity and the offsetting of Schumpeterian gains from backwardness. Second, the introduction of a new method of technological change, loosely termed "modern R\&D" such as culminated in the late 19th century with the modern R\&D laboratory (the rise of institution such as government research agencies, scientific academies, universities with close to industry etc.) gives rise to the possibility of an important and discrete shift in $\lambda^{\prime}>\lambda$. However, only countries with with a threshold level of skill could undertake this "modern R\&D"' and Howitt \& Mayer-Foulkes (2005) show that this results in the emergence of three equilibria. Countries with a skilled enough labor force to undertake modern R\&D immediately start growing faster. Countries with skills too low to do R\&D but not too far behind will have the absorptive capacity to continue to implement foreign technologies, and will follow a growth path parallel to the first country, but with a magnified initial gap in level. Countries with even lower absorptive capacity will grow less than the common growth rate of the first two countries and diverge ${ }^{38}$

\footnotetext{
${ }^{37} \mu$ is a measure of the country's "competitiveness" in the sense that a higher value of $\mu$ means more innovation for any given relative distance from the frontier and world growth rate.

$$
\mu=\lambda^{\frac{1}{\eta}}\left[\frac{1-\eta}{1-\phi} \beta \pi\right]^{\left(\frac{1}{\eta}\right)-1} \xi
$$

where $\phi$ is a proxy for distortions and policies that impinge on the incentive to innovate and $\pi$ is a profit parameter that suggests that in countries where geography, policies and institution make productivity higher, competitiveness rises, even if they do not affect the innovation process directly. Hence, $\mu$ is increased by the incentive to innovate, the profitability of innovation; the productivity of the innovation process, $\lambda$, the incentive to save $\beta$, and the quantity or quality of education $\xi$.

38 Howitt (2000) offers a similar result of complete stagnation.
} 


\section{A.2 Annex II: Construction of Engineering Data}

\section{A.2.1 Argentina}

The principal source is Historia de la Ingeniería Argentina (Centro Argentino de Ingenieros, 1981). At the end of the 19th century, there were three universities that granted the title of civil engineer which was their omnibus term for engineers- Buenos Aires, Cordoba and La Plata as well as a school of mining engineers in San Juan. The CAI documents that from 1870, the year when the first engineers graduated in the country, until 1900, 250 engineers received their diplomas. We do not know the distribution of these degrees across years so we impute uniform graduation rates after which the attrition adjustment leaves 196 or a density of 1239

\section{A.2.2 Bolivia}

In Bolivia, the first engineering school, the Escuela Nacional de Ingenieria in Oruro, began in 1917 and hence Bolivia has 0 locally trained engineers by 1900. As late as 1937, 84\% of engineers in the Patiõ Tin mines (accounting for 10 of world production) were foreign (Contreras, 1993).

\section{A.2.3 Brazil}

Telles (1994) Historia da Engenharia no Brasil, Seculos XVI a XIX is the principal source. In 1858 the Royal Academy of Artillery, Fortification and Drawing, established in Rio de Janeiro in 1792, dedicated itself to civil engineering for the first time, studying steam engines and railroads, and in 1874 it became independent of the Military and became the Polytechnical School of Rio (today the School of Engineering of the Federal University of Rio de Janeiro). This was the dominant institution for training engineers. Brazil's second engineering school was founded around Mining in Ouro Preto. However, the low motivation for technical teaching of the time the school's isolation, among other social factors, made it difficult to recruit students and it graduated few. From 1894 to 1896 four new schools were started in Saõ Paolo, Pernambuco, Porto Alegre and Salvador. Telles (1994) suggestion that these schools

\footnotetext{
39 A later data point is offered by Almada \& Zalduendo (1962), which, when adjusted to be compatible with our data, yields a density of 41.25 in 1925. Given the rapid increase in output of engineers in the beginning decades of the 20th century in most countries, this supports our 1900 estimate.
} 
would eventually end the Polytechnical School of Rio's monopoly confirms the dominance of the latter in the production of engineers up to that point. We do not, however, have a long time series on graduates from any program. Telles reports the average annual number of domestic engineering graduates in Brazil as a whole for the period after 1890 at 45 per year, half of them produced in Rio by 1900. To estimate graduation rates for the 1860-1890 period, we rely on evidence from reported stocks. Telles tabulates the number of engineers in Rio as reported in Almanaque Laemmert, a periodical dealing with governance, commerce and industry in Rio, for 1854, 1870, 1883 and from the official Almanak dos Engenheiros an official publication of the government for the whole country in 1906. In Rio in 1854, there were 6 engineers and in Saõ Paolo, the other principle locus of engineering talent, in 1857, there were 5. We therefore set 11 as our initial stock for the country in 1860 . In 1870, the Almanaque Laemmert notes that Rio had grown to 28 engineers and by 1883, 126 (page 593). Given the rough earlier parity of Rio and Saõ Paolo in 1854-57, we double the Rio numbers figures to get national figures for these periods. While the Almanak may be overstating the stock by including non degreed engineers, the implicit graduation rate leading up to 1883 is roughly 15 per year which is substantially below Telles' documented graduation rate of 45 beginning in 1890. On the other hand, the consolidation of the Ouro Preto School of Mines and the new schools established after 1890 doubled whatever Rio's capacity was and that was likely substantially more in 1890 than prior. Hence, a three-fold increase over the last two decades seems plausible. We interpolate an average value between the known values of 1883-1890. Together, these lead to a total stock in 1900 of 786 . If we extrapolate at the same graduation rate, the terminal stock in 1906 is 968 or slightly above the value reported by the official Almanak (941) suggesting that we may, again, be overstating the stock somewhat. Density 12 .

\section{A.2.4 Canada}

McInnis (2004) is perhaps the most complete of a thin literature. Substantial engineering curricula had been introduced at King's College (UNB), at McGill College, and the University of Toronto in the 1850s although demand for engineering education gained traction only in the 1870s. McGill offered a full diploma course by 1863 although the first five students 
graduated only in 1874. Four year courses were implemented in Civil Engineering, Mechanical Engineering, Practical Chemistry and Mining by 1878, Electrical engineering in 1891, Chemical Engineering and Metallurgical Engineering in 1908. The University of Toronto School of Practical Science opened in 1878 and offered the degree of civil engineer in 1885. In 1874, Laval University established an Ecole Polytechnique which emitted its first graduates in 1877. Other smaller programs also emerged at the same time. Also of importance, The Royal Military College in Kingston Ontario, established in 1876, with West Point as a model, explicitly had the dual object of providing scientific training to military officers as well as producing civilian engineers 40 If we take the discounted sum of the licensed graduates plus half the military graduates ${ }^{41}$ by 1900 we reach a total density of about 41 . This is relatively low by US standards especially given the number of institutions offering engineering courses, as well as the articulation of the different fields of engineering at a relatively early phase. The development of, for instance, mechanical engineering as a separate course about 20 years after in the US, Electrical Engineering 10-15 years after, but still far ahead of any of the Latin Universities in the sample. Electrical engineering appears more or less at the same time as in the US. It is worth noting, however, that the four principle Canadian Universities emitting graduates lay within a circle of 350 mile radius with Cornell at its center and including many of the principle US universities of the time. Density: 41

\section{A.2.5 Chile}

As Serrano (1993) notes in Universidad y Nación: Chile en el Siglo IX, training at the Universidad de Chile (University of Chile), the principal source of engineers in the 19th century, began in the mid-1850s. Prior to this, there were effectively no schools in Chile and those engineers trained abroad were very few. From 1846-50 there had been 2 fellowships to study abroad with uneven results. Serrano notes (p. 216) that between 1856 and 1879, 100 geographical engineers (surveyors/geographers), 61 mining engineers and 4 civil engineers plus 11 general assayers graduated. This gives us a graduation rate for the first 20 years of our exercise. To anchor the subsequent 20 years, Villalobos et al. (1990) collaborating with Ser-

\footnotetext{
${ }^{40}$ http://www.warmuseum.ca/education/online-educational-resources/dispatches/the-royal-militarycollege-of-canada-1876-to-the-present

${ }^{41}$ our thanks to Marvin McInnis for discussions on this
} 
rano in Historia de la Ingeniería en Chile, offers that "in the 19th century there were 130 Chilean engineers and toward 1938, the country had a list of 270 professionals graduating from the University of Chile. They created, in 1930, the Institute of Mining Engineers of Chile" (p. 198). The context may be taken to suggest that we are talking exclusively about mining engineers, although in personal communication, Serrano confirms that it is total graduated engineers. This is consistent with the fact that the implicit graduation rates from the pre -1879 period, 2.3 mining engineers per year, respectively accumulates to only half of the 130 number cited by Villalobos at end century. Clearly, this gap could be made up by a rapid expansion in number of graduates from 1879 on, but as Serrano notes, in 1867 the government expressed concern that the numbers of graduates in physical studies and mathematics was actually decreasing (page 212) so this would have represented a reversal in trend. Geographical engineers translate broadly as surveyors/geographers which are not generally treated as engineers per se and hence, to the degree that they are included in the 130 number, this overstates installed capacity. Density: 17.

\section{A.2.6 Colombia}

As Safford (1976) notes in his The Ideal of the Practical: Colombia's Struggle to Form and Technical Elite, the process of establishing a technical class was undermined by recurrent civil wars which often whipsawed the ideological foundations of the schools when they were not closing them, and perennial shortages of funding. The Universidad Nacional (National University), founded in 1867, was the dominant source of degreed engineers. It was built on the Colegio Militar (Military College) which operated over two brief periods, 1848-1854, and then in 1861. In the early 1880s, the Congress also authorized the creation of mining schools in Antioquia, Rionegro, Popayan and Ibague but most were aborted by the civil war of 1885 . Safford (1976). The exception was the Escuela Nacional de Minería (National Mining School) in Antioquia set up in 1887 to 1895, that would eventually close due to a lack of financing, among other factors, and become part of the Escuela de Ingeniería de la Universidad de Antioquia (Engineering School of the University of Antioquia). Poveda Ramos (1993) in Historia Social de la Ciencias en Colombia: Ingeniería e Historia de las Técnicas summarizes "By the end of the century, there were only three schools of engineering in Colombia: the 
Universidad Nacional, the Escuela Nacional de Mineria, and the Universidad Republicana (Republican University) in Bogota. The number of students was small, so much so that the National University, the largest of all, the number of students fluctuated from one year to another between 25 and 50."(p.55). The Universidad Republicana (now the Universidad Libre Free University) was begun in 1890 but it nearly collapsed financially by 1910 and its contribution to our accumulated stock is likely to be small. Facultad de Ingeniería (2011) tabulates that from 1868-1870 enrollments in the National University averaged 35 per year, yet graduates in the $1871-1875$ period average about 4 per year. Though the authors note that their tabulations may not be complete, the virtual absence of graduates from 1876 to 1888 is plausible as from 1876 to 1884 the school was again taken over by the military and oriented away from industry related training. In 1880, despite 56 enrolled, higher mathematics and engineering classes contained only 4 students. (p. 195). In the National School of Mines, from 1887 to 1890 average enrollment was 25 students. Safford notes 63 alumnai of the 18881894 period, which is confirmed by Santa-Maria Alvarez (1994) as the number of "egresados" (exiters) of the program. However the same text notes that only five of these had graduated with thesis across the period (in 1893 and 1894) and none again until 1906 (Annex 5 page 103). Poveda Ramos (1993) confirms the lower numbers noting that the first 3 degrees of Mining Engineer were granted in 1893. The two schools together yield an accumulated stock of 75 Engineers by 1900. This is broadly consistent with Safford's finding of "more than 200 Colombian engineers and surveyors "in 1887 derived from the Anales de Ingeneiría (Annals

of Engineering), the organ of the Colombian Engineering Association Safford (1976) page 219) which, again does not discriminate by whether or not the inscribed had completed a degree, nor separate out surveyors. However, we also know that both the University of Cauca as well as the Republican University in Bogota were generating some unknown quantity of graduates. We round to 100 as number that would incorporate these and missing graduates from Antioquia and the National University. Density: 5.

\section{A.2.7 Denmark}

The Polyteknisk Laereanstalt was founded in 1829 as the first university level technical school in Copenhagen and was one of the first of its kind in Europe and was heavily influenced by the French Ecole Polytecnique. Harnow (1997) in his study of the impact of engineers in 
Denmark only focuses on this school, arguing that from 1850 to 1920 it was by far the most important Danish technical institution. He tabulates the number of graduates across the period 1832-69 and then for roughly 10 year periods after. Taking the yearly graduation rate as the average of each period and then applying the usual discounting yields a density of 92 .

\section{A.2.8 Ecuador}

The Escuela Politcnica Nacional (National Polytechnical School) was founded in 1869 by the President Gabriel Garca Moreno with the aim of establishing a center for research and training of engineers and scientists at a high level. German Jesuits were brought for the purpose but the school was closed in 1876 for political reasons and was only reopened in 1935 . This trajectory is not so different from that of Colombia's School of Mines, although that country had two other universities for more or less three times the population. We can't know the number of graduates of the program, over these seven years, but the density would have to be less that than of Colombia, including that until 1935 there was effectively no local training capacity which is part of what we're trying to capture here. http://www.epn.edu.ec/ index $\cdot$ php?option=com_content\&view=article\&id=1129\&Itemid=378. We assign a value of 2 .

\section{A.2.9 Mexico}

The earliest technical training in Mexico was the Colegio de Mineria formerly the Real Seminario de Mineria (College of Mining, Royal Seminary of Mining) in Mexico city which opened in 1792 and was perhaps the most secular and highest quality technical institution in the hemisphere at the time. Bazant de Saldaña (1993) in her Historia de la Educación Durante el Porfiriato has best documented the subsequent evolution. Wars of independence, foreign invasion, and perilous fiscal situations led to a steady decline and by the time it was transformed into the into the Escuela Nacional de Mineria (National School of Mines) in 1867 under Benito Juarez, the number of students was so low that the government considered closing it and sending the 8-10 students abroad. Porfirio Diaz would subsequently put great emphasis on engineering as part of his modernization compaign. Despite this, by 1902, still only 18 engineers were graduating per year. Flows from the National School of Mines from 1876-1901 total 327. From 1876 to 1880 (41); 1881-1890 (106); 1891-1901 (180). Most other 
universities in other areas contributed very few. Allowing for another 16 years prior at the 1877 rate, which likely overstates the case, gives a total stock in 1900 of 336 or a surprisingly low density of 5 . Other figures broadly corroborate. The census reports 884 engineers for Mexico city or roughly half the total that it reports for the entire country. Applying that ratio to the stock above gives 159. By comparison, Bazant cites the Massey Blue Book, an English language director of Mexico (City) as giving a total of 91 engineers and the Directorio de Vecinos de la Ciudad de Mexico as 183, both including some unspecified number of foreigners. The Association de Ingenieros (Engineering Association) in 1910 counted 255 members which, again, is not clear on the level of education of its members and may also include both the acceleration in graduation at the turn of the century in many countries. In all, the magnitudes do not suggest that our stocks are importantly underestimated. Density of 5 .

\section{A.2.10 Peru}

Although there were institutions teaching technical skills in various parts of the country, modern engineering began in Peru in 1852 two French and one Polish engineer to design and undertake public works of engineering. The need to import talent for these tasks, as was the case elsewhere in Latin America, testifies to the dearth of locally generated qualified human capital. The first school of engineers was discussed in the early $1850 \mathrm{~s}$, but only became reality when the Peruvian sbtate in 1876 invited Polish engineer, Edward John Habich, to advise on irrigation, railways and other projects as well as the founding of a school of mines. Lopez Soria (2012) in Historia de la Universidad Nacional de Ingenieria, los Años Fundamentales, 1876-1909 notes that the resulting School of Civil Construction and Mining Engineers (now the National Engineering University-Universidad National de Ingenieria) opened in 1876 and graduated its first class of 4 in 1880. The school was heavily damaged when used by the invading Chilean forces in 1880 and took several years to rebuild, only graduating one more student by 1882. Lopez Soria (2012) tabulates annual list of graduates going forward, disaggregated by specialty and allowing us to take out surveyors and include only industrial, mining and civil engineers, giving a total net of attrition of 100. This broadly confirms the statement by the Sociedad de Ingeneiros Del Perù(Peruvian Engineering Society) (established 1898) of "more than 80" engineers in the country. This 
gives us a density of 5 .

\section{A.2.11 Portugal}

Formal training of non military engineering in Portugal did not begin until the turn of the 20th century with the Instituto de Lisboa (Institute of Lisbon) which started training industrial engineers in 1903 (Heitor et al), and the Instituto Superior Tcnico (Higher Technical Institute) founded in 1917 Diogo (2007)). Hence, we are unable to generate a stock of graduates as in many of the other cases. Diogo argues, however, that military engineers were responsible for most civil engineering projects and hence military engineers should be counted in this case. The Associao dos Engenheiros Civis Portuguezes - AECP (Portuguese Association of Civil Engineers) also did register the majority of those who considered themselves nonmilitary engineers. Though registration in the AECP was not mandatory to be a practicing engineer, it was mandatory in the organization that followed, the Ordem dos Engenheiros (OE) (Order of Engineers). In 1870 the AECP reports 150 inscribed; in 1926, 733. We take the average growth rate between the two points and impute the value for 1900. After 1900, we are able to compare the rates between the AECP and the mandatory OE: in 1930, there were 845 members (AECP) and in 1936, 1127 members (OE). Imputing the same growth rate between 1930 and 1936 as previous suggests that the AECP is understating the stock of practicing engineers by roughly $20 \%$. We apply this to the stock value generated using the AECP data for 1900 to yield 579 or a density of 22. This is likely to be an overstatement since we do not know what fraction of these had any higher educational training.

\section{A.2.12 Spain}

We offer two estimates of the stock of Spanish engineers derived from Riera i Tuebols (1993) from 1867 Industrialization and Technical Education in Spain, 1850-1914 and López et al. (2005) Estadisticas Históricas de España: Siglos XIX-XX from 1857. The estimates differ in scope. Riera i Tuebols reports graduates of escuelas de ingeniera engineering schools as such, starting with Spain's first, founded in Barcelona in 1867, to train industrial engineers (see also Riera, 2008). He also offers data from mining and civil engineer graduates primarily from institutions in Madrid. Though Riera's tabulations are the most accurate count of certifiably degreed engineers from university programs available, the resulting stock, 892, may be a 
lower bound. López et al. (2005) casts a broader net, including information from all technical schools (including Escuelas Nacionales, Escuelas Superiores, Escuelas Especiales, Escuelas Centrales, Escuelas Profesionales and Escuelas Elementales). Although this compendium is more comprehensive geographically, the estimates include graduates from other technical disciplines potentially miscategorized as engineers as well as including graduates of indeterminate level of training. We treat the resulting estimate of 3,089 as an upper bound. The Riera number is roughly half of the number of engineers and architects combined reported in the 1900 census. The Lopez is about 50\% higher, which makes it the only case among our countries where the accumulated estimate is above that reported in the census. Since, as noted, self-reported census definitions are looser than documented degrees conferred, we find this improbable. Density either 12 or 42 respectively and we plot the average of the two. In our regressions, the Spanish influence is accounted for by a dummy so our results are unaffected by these estimates.

\section{A.2.13 Sweden}

The reference here is Ahlström (1993) who tabulates graduates of the two principal engineering programs. The Kungl Tekniska Hgskolan (KTH) or Royal Technical University in Stockholm has roots in the Laboratorium Mechanicum founded in 1697, which later became the Mechanical school (1798). The Chalmers Institution in Gothenburg, founded in 1829, provided technical education equal to that of the KTH. Ahlstrm argues that in the mid 19th century, "...anyone in Sweden who sought an internationally reputable technical education could find it in these institutions." Density is 99.

\section{A.2.14 United States}

\section{National data:}

We draw on several sources for the US engineering numbers. First, Mann (1918), in his Study of Engineering Education done for the Joint Committee on Engineering Education, tabulated graduates from US schools until 1915. As of 1900 this gives a total of 14,679, which gives a density per 100,000 workers of 50. However, as Adkins (1975) in The Great American Degree Machine: An Economic Analysis of the Human Resource Output of Higher Education notes, before 1940, the Office of Education made no effort to maintain comparability across years 
or completeness of coverage of educational institutions. It is not clear how they identified the universe of relevant institutions and, if an institution did not respond to their survey two years in a row, it was dropped from the interview rolls. Hence, Mann's estimates underestimate the true stock by a potentially significant amount. To bring to bear other sources of information, we use more reliable graduation data in select states or periods to calibrate the Census numbers, and then impute engineering stocks for the country in 1900. First, Adkins' tabulations for the US in 1930 yield a stock that is .53 of the census declaration

of occupations in engineering at that time. Second, Edelstein (2009) in The Production of Engineers in New York Colleges and Universities, 1800-1950 offers a full and comprehensive stock accounting for the state of New York for our time period 1900. His tabulations yield a density of 179 which is .67 of the US census number corresponding to New York that year. It is likely that New York's number may have a higher density of fully degreed engineers selfreporting in the census than the country as a whole so this number may be somewhat high. Similarly, Adkins' estimates for the whole country in 1930 may reflect that, in the ensuing 30 years, a higher share of self-declared engineers actually had degrees. Mann's numbers yield a ratio of .39 which we expect to be too low for the reasons outlined above. Hence, we take an intermediate value of .5 as the national ratio of actual graduates to Census declared engineers in 1900 and the data for the South and the North are projections based on this ratio. This yields a density of 84 for the entire country, 160 for the North, and 60 for the South.

\section{County level data}

Innovative capacity: As elsewhere we calculate density by engineers per 100.000 male workers. We use OCC1950 variable of IPUMS USA for 1880 census and we aggregate all categories for set up engineers: Engineering, chemical engineers, civil engineers, electrical engineers, industrial engineers, mechanical engineers, metallurgical and metallurgists engineers, mining engineers, and other engineers. We use as proxy of male workers the $40 \%$ of population because there are inconsistencies in labor force variable. Patenting is the collected number of patents between 1890 and 1910 like proportion to 1880 population. Number of patents was collected from Akcigit et al. (2013) and include all patents granted by the USPTO.

Sub-national Income in 2005 US Dollars is the household mean income drawn from 2000 USA 
Census.

Geographical Controls: we include temperature, altitude and rainfall taken from Worldcrim. We use distance to river (distance between the county centroid to the near medium or big size river) derived from HydroSHEDS (USGS 2011). We employ a measure of distance to the coast calculated like distance between centroid and the near coast similar to Gennaioli et al. (2013). We further include a measured of ruggedness of terrain from Nunn \& Puga (2012).

Growth variables: Population Density in 1880 as a measure of agglomeration is taken from the 1880 census data. As a measure of lagged economic activity, we calculate two measures using manufacturing output, taken from the 1870 NHGIS. Per capita yields a measure of structural transformation, per manufacturing output a measure of productivity. The extreme values and high variance of manufacturing employment suggests some lack of confidence in the 1880 labor allocation data so we report only the first measure. However, the results do not change appreciably using the other. We use slavery as a measure of institutions taken from the 1860 Census as well as Nunn (2008). For railroads, we employ two variables from the Nebraska-Lincoln University railroads data. An identifier variable if the county has railroad or a railroad density variable.

Human capital: Aggregate literacy rates we take from 1880 Census. As with engineers, we measured lawyers and physicians density per 100.000 habitants. We use the OCC1950 variable of IPUMS USA for 1880 census. Lawyers and Physicians categories are used from OCC1950.

Instrument: we compute the distance between the county centroid to the near the 571862 Land Grant Colleges.

\section{A.2.15 Venezuela}

Mendez (2013) in Historia de la Tecnología en Venezuela notes that the Universidad Central de Venezuela $(U C V)$ (Central University of Venezuela), as it would eventually be known, 
become the primary source of engineering graduates from 1867 on: 8 from 1867 to $1879 ; 80$ from 1880 to $1889 ; 102$ from 1890 to 1899. Other universities that graduated engineers were la Universidad del Zulia (University of Zulia) (1 in 1892) and the Universidad de Valencia (University of Valencia) (4 between 1892 y 1904); Colegio Federal de Maracaibo (Federal College of Maracaibo) 1886 (5) who submitted their these to the UCV for approval. To fill in the 1860-1866 period, we take the average of graduates from Academia de Matemticas de Caracas (Academy of Mathematics of Caracas)from 1831 to 1872 (97 graduates) perhaps half of which were employed in civil or industrial work. Applying our usual discounting gives about 185 engineers. The engineering association gives 196 although this may include foreigners and members of undetermined educational attainment. Density: 11.

\section{A.3 Annex III: Details on controls}

\section{A.3.1 Controls}

As controls in our regressions, we also employ data on:

Literacy: Aggregate literacy rates we take from (Mariscal \& Sokoloff, 2000; Núñez, 2005). Sub-national literacy rates for Argentina, Chile, Mexico, Venezuela, and the US taken from same census data as above. County level from 1880 census.

Secondary Schooling: Similar to Goldin \& Katz (2011); Goldin (1999) for the US we construct a proxy for secondary schooling by the share of 14-17 years olds who report that they are attending school (1880 US census).

Higher Level Non-Engineering Human Capital: For the US, this is measured as number of lawyers and medical doctors per 100,000 inhabitants (US Census 1880). We also aggregate across occupational categories the EDSCOR50 measure that indicates the percentage of people in the respondent's occupational category who had completed one or more years of college. Together these allow us to ensure that our engineering measure is not proxying for the availability of higher order human capital in general.

Railroads: At the national level, we employ the density of railroads measured as kilome- 
ters of track per 1000 square kilometers in 1900 (Pachón \& Ramírez, 2006; Thorp, 1998). At the sub-national level, we employ the Interstate Commerce Commission's data on miles of track per 100 square miles converted to the same units above for consistency in 1899 (ICC, 1899). Individual country sub-national data is not available for Latin America. At the county level we use an indicator variable showing the presence, or not, of a railroad.

Mining: For the US state level it is the total mining output in 1880 in $\$$ US 100,000.

Manufacturing output per capita: The value of manufactured products and labor in manufacturing in 1870 taken from NHGIS to compute the per capita and per unit of labor labor manufacturing product. 42

Population Density in 1900: These are collected from census data from the individual countries. Argentina (1895), Brazil (1900), Chile (1907), Colombia (1912), Mexico (1895), Peru (1876), Venezuela (1926), and the US (1900).

Pre-colonial Population Density: This measures the estimated number of indigenous people per square kilometer just before colonization. See Maloney \& Valencia (2016) for more detail.

Slavery: As a measure of institutions that is available for the United States sample, we used the 1860 Census as well as the data compiled in Nunn (2008).

Foreigners: Total foreign born people per capita taken from the 1880 census and University of Virginia Historical Census Browser (UVCB).

Agriculture: Total number of farms normalized by county population, taken from the 1880 census (UVCB).

Religion: Total churches at the county level, taken from the 1860 census. These cen-

\footnotetext{
42 https : //www .nhgis .org/documentation/gis-data
} 
suses also distinguish by faith, including: Roman Catholic, Presbyterian, Methodist, Baptist, Christian, Union, Jewish and Episcopal. (UVCB)

Geographical Controls: in addition to the set of sub-national geographical variables collected by Bruhn \& Gallego (2011) including temperature, altitude, and annual rainfall, we add a measure of agricultural suitability and river density as developed in Maloney \& Valencia (2016). Distance to the coast as calculated by Gennaioli et al. (2013). We further include a measured of ruggedness of terrain from Nunn \& Puga (2012).

\section{A.3.2 Intermediate mechanisms of influence}

1930 census allows us to generate several proxies for structural change, technological upgrading and entrepreneurship.

Structural change and technological upgrading: manufacturing value added per inhabitant, manufacturing establishments per capita, and horsepower per manufacturing firm. We follow value added from 1860 to 1930 using the corresponding censuses.

Entrepreneurship: Number of wholesale and retail stores per capita, net wholesale sales per capita. 


\section{A.4 Annex IV: The US at the State Level}

We now look more closely at the US sub-sample alone since the 1900 census offers several other correlates that allow us to test the robustness of the engineering results (Table A2). The cost of these additional covariates is the reduced number of observations (51). The geographic variables for this sample are not significant as a block and we drop them to preserve degrees of freedom ${ }^{43}$ The magnitudes of the remaining coefficients are not sensitive to this omission. In columns 1-3, Engineering enters significantly freestanding, with population density, and literacy included sequentially and entering significantly and positively as before.

We test the robustness of this result in two ways. First, the US sample allows progressively adding a richer group of controls. Following Murphy et al. (1991) for the present day, in column 4 we include the density of lawyers. This does not alter the magnitude of the engineering variable suggesting that we are not picking up simply higher order human capital. In column 5 we add state-level measures of railroad density and mining activity which, again, capture infrastructure or industrial activity that engineering may be proxying for. The former enters significantly and positively although mining does not and engineering continues to remain significant and of similar magnitude.

It is also possible that engineering is proxying for the institutional differences across states, and in particular, the legacy of slavery. We employ slavery data from Nunn (2008) which reduces our sample to 38 observations. Consistent with Nunn (2008), slavery alone (not shown) enters negatively and significantly. However adding engineering eliminates its importance, while engineering density itself remains strongly significant (Column 6). This suggests that weak engineering capacity is one possible channel through which the institution of slavery depressed Southern incomes ${ }^{44}$

Including all variables (Column 7) renders many insignificant although engineering prevails. Though we are pushing the data hard given the limited degrees of freedom, engineering

\footnotetext{
${ }^{43}$ Given the small number of observations, we also bootstrap the standard errors. The results remain unchanged.

${ }^{44}$ Taking the parameter value on engineering from the most complete specification (Column 7), the difference in engineering density between the North and the South could account for a log difference of .12 or roughly 13 percent which is, in fact, larger than the difference that currently exists between the two regions.
} 
retains its significance after controlling for agglomeration effects, other higher order human capital, sectors using engineers that may have an independent effect, and institutions.

Second, though we have controlled for the two activities most related to engineering, we also attempt to instrument engineering density using the number of Morrill Land Grant colleges and universities found in each state. As discussed earlier, the Morrill program was introduced in 1868 precisely to remedy the perceived shortfalls in regional technical assistance in agricultural and mechanical innovation. In practice, this program financed the first engineering departments in the emerging West and Midwest and especially in the South. It was to an important degree supply driven. Prior to the Civil War, the South had actively opposed the bill, fearing greater interference in matters such as universal primary education. The withdrawal of the Confederate States from the US Congress allowed the bill to be passed. However, during Reconstruction, recognizing its technological lag, the South started privately some universities such as Georgia Tech, and actively embraced the Morrill Program.

The first stage reveals a strong and negative correlation between engineering density and the Morrill uptake, suggesting the role of the program as a remedial supply side effort 45 As discussed earlier, Morrill financed programs in Texas, Virginia, Kentucky, and North Carolina began awarding degrees in the 1880s and 1890s which means that their accumulated engineering stock would still be low in 1900. Table A3 presents the second stage results. Though we have few degrees of freedom, engineering enters significantly in all specifications despite sequential addition of agglomeration, literacy and lawyers as controls. The coefficient is significantly higher in all specifications suggesting that the instrument is, in fact, helping to overcome an important downward bias.

In sum, the various estimations offer support to the idea that higher order human capital and institutions related to engineering and science and technology at the turn of the 20th century plausibly are important to explaining present prosperity.

\footnotetext{
${ }^{45}$ With 51 observations, this exercise is somewhat heroic and diagnostics should be taken as suggestive. Both the first stage Cragg-Donald $\mathrm{F}$ test and Anderson-Rubin test of joint significance of regressors are marginally acceptable suggesting that attempting to instrument is informative. Using the second wave 1890 Morrill grants yields stronger diagnostics although there is less clarity on the selection criteria and hence we prefer using the 1868 wave. Both yield similar second stage results.
} 


\section{Figures and Tables}

Figure 1: Income 1900 and Engineering Density 1900

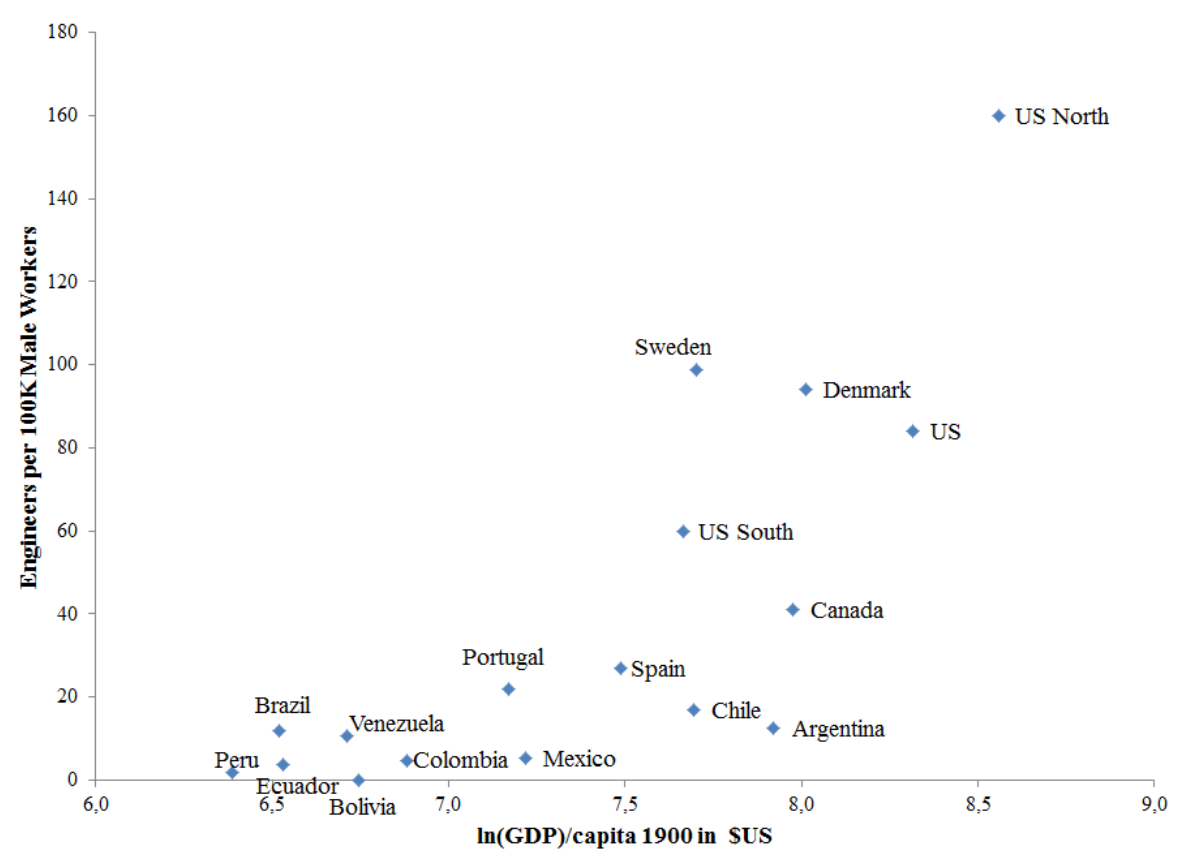

Note: Plot of GDP per capita in 1900 from Maddison. Engineering Density is accumulated graduates of engineering programs per 100,000 male workers around 1900 as described in the Annex. 
Figure 2: Sub-national Engineering Density, US and Mexico, in 1900

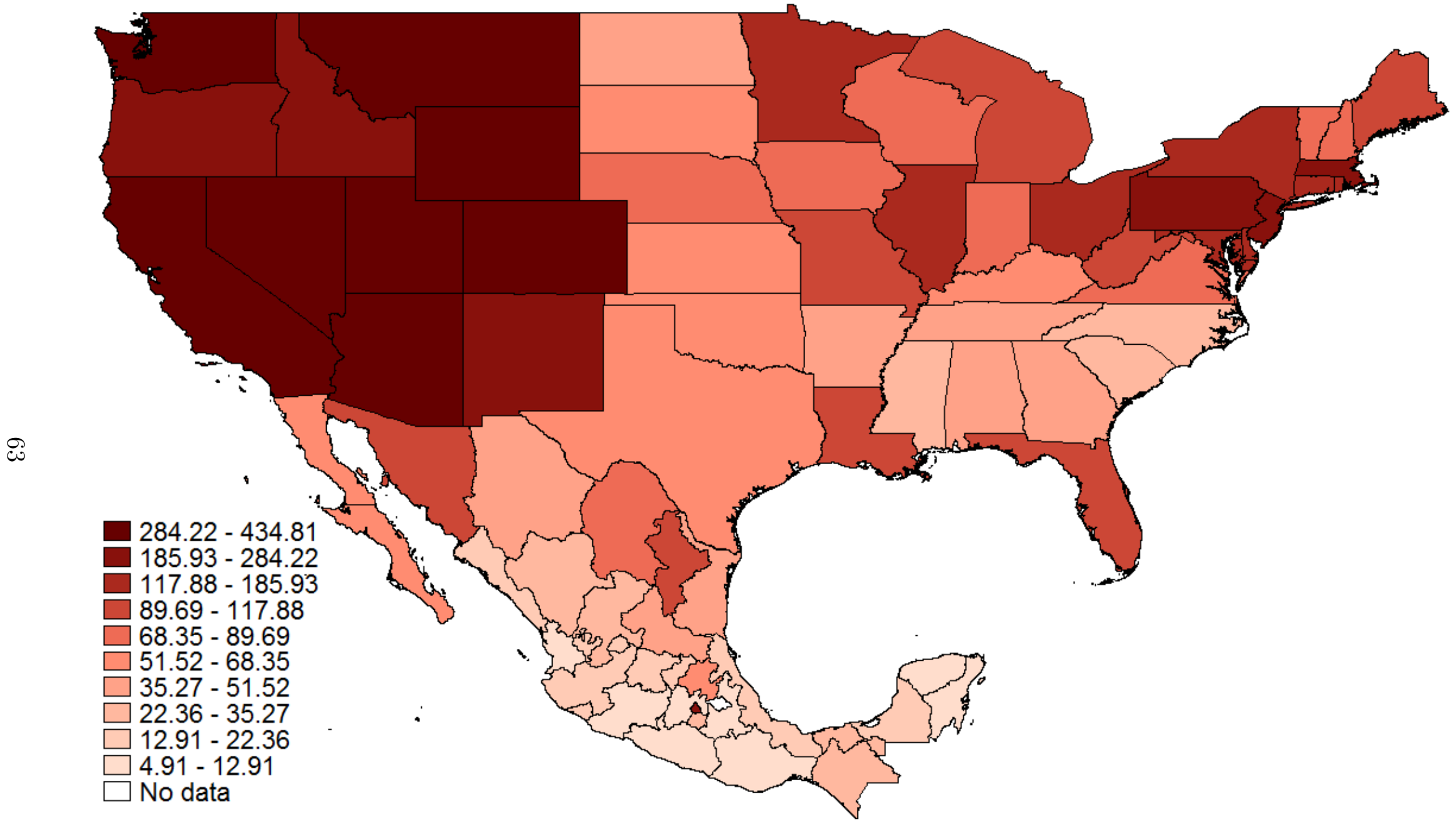




\section{Figure 3: Copper Production in Chile and Foreign Engineers}

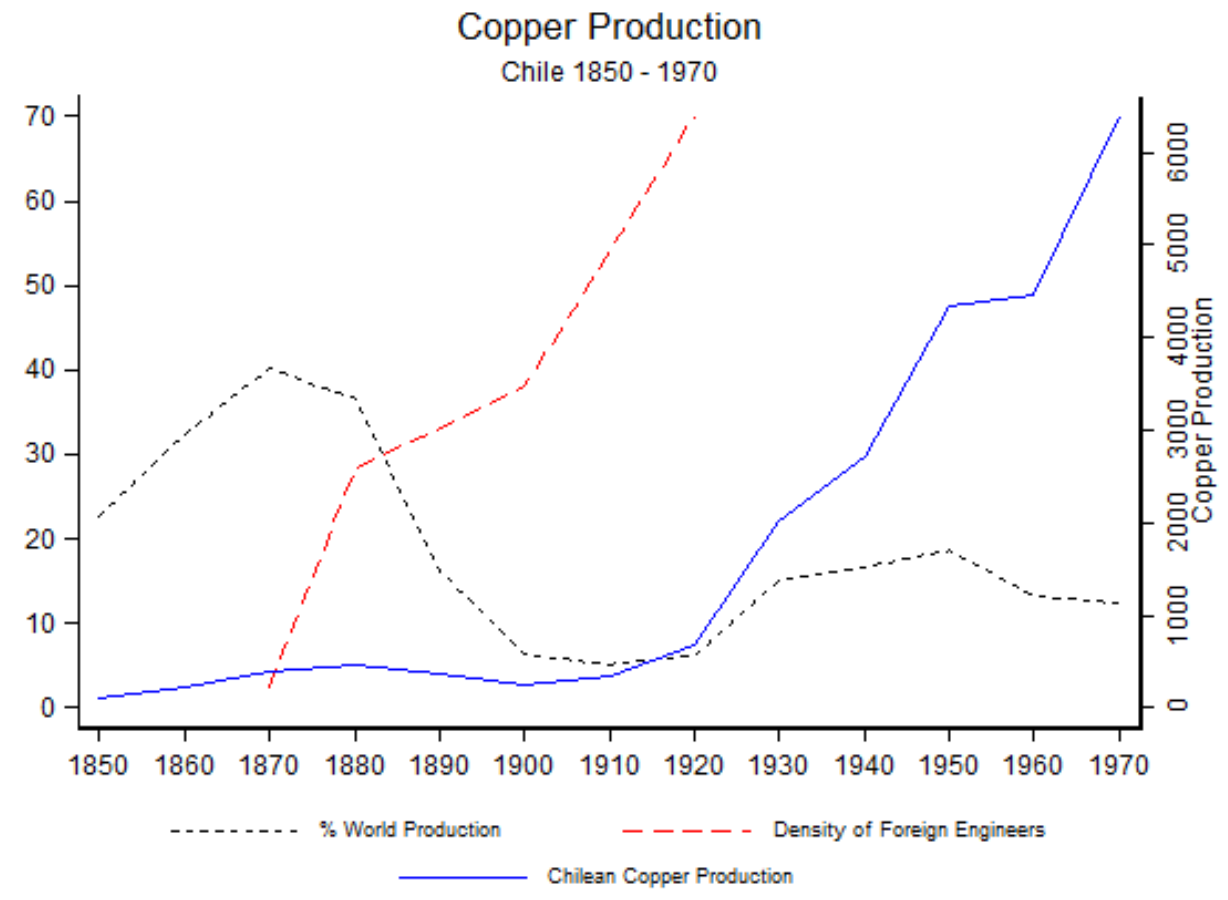

Note: The figure shows the decline in Chilean production and share of the world market for Copper approaching 1900 and then the sharp recovery with the entrants of foreign mining companies and engineers in 1905 . Engineering density per 100,000 male workers calculated from National Censuses available until 1920 when Chile ceased to divide by profession-origin. 
Figure 4: Engineering Density on Manufacturing Value 1860-1940

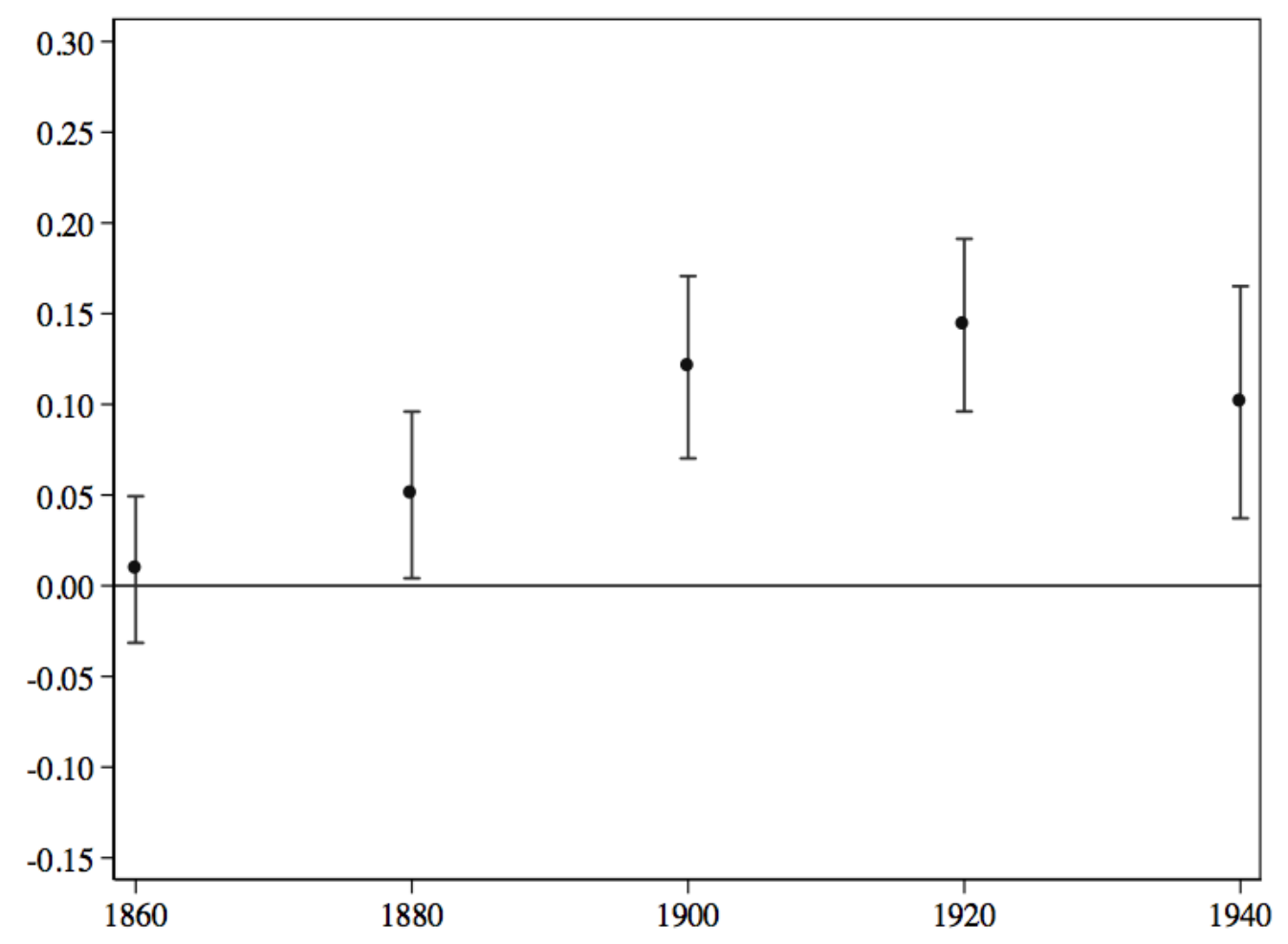

Note: The figure plots the coefficient of engineering density on manufacturing value added at 20 year intervals from 1860 to 1940 . Controls included are mentioned then. Rainfall captures total yearly rainfall in meters; Altitude measures the elevation of the capital city of the state in kilometers; Ruggedness of Terrain from Nunn \& Puga (2012); Rivers captures the distance between the near river and the county. Rivers taken from HydroSHEDS (USGS 2011). Temperature is a yearly average in degrees Celsius; Dist. to Coast is distance between the coast and the county centroid. Population density is number of individuals per 100 square kilometers in 1880. Slavery to county level is taken from Nunn (2008). Farms per capita is the number of farms per capita retrieved from University of Virginia Library. Railroad is a identifier variable if the county has railroad. Beta coefficients. Robust and clustered SE reported. Lines mark 95\% confidence intervals. 
Table 1: Summary Statistics (State Level, Americas)

\begin{tabular}{lcccccc}
\hline Variable & mean & p50 & sd & min & max & obs \\
\hline Ln Income & 9.03 & 8.92 & 0.91 & 7.13 & 11.18 & 377 \\
Engineers & 23.38 & 11.00 & 30.08 & 0.00 & 84.00 & 275 \\
Engineers (sub) & 82.07 & 39.68 & 105.70 & 0.00 & 472.59 & 170 \\
Population Density (1900) & 41.06 & 4.44 & 243.20 & 0.00 & 3319.27 & 235 \\
Population Density (1500) & 8.88 & 2.00 & 26.13 & 0.00 & 392.34 & 365 \\
Literacy & 40.85 & 34.00 & 23.95 & 11.30 & 86.70 & 337 \\
Literacy (sub) & 49.06 & 39.96 & 30.10 & 4.60 & 98.31 & 175 \\
Railroads & 3.15 & 1.80 & 2.71 & 0.30 & 9.30 & 377 \\
Railroads (sub) & 65.12 & 48.54 & 57.46 & 5.16 & 309.20 & 49 \\
South & 0.15 & 0.00 & 0.36 & 0.00 & 1.00 & 111 \\
Slavery & 20.67 & 3.28 & 25.16 & 0.00 & 72.66 & 83 \\
Lawyers & 218.92 & 139.22 & 210.93 & 1.64 & 1156.44 & 114 \\
Mine Output & 0.47 & 0.12 & 1.06 & 0.00 & 6.49 & 45 \\
Spain & 0.81 & 1.00 & 0.39 & 0.00 & 1.00 & 390 \\
Land Suitability & 0.56 & 0.58 & 0.28 & 0.00 & 1.00 & 384 \\
River Density & 3.28 & 3.29 & 1.23 & 0.00 & 6.92 & 386 \\
Average Temperature & 19.97 & 20.40 & 5.83 & 2.38 & 29.00 & 332 \\
Rainfall & 1.28 & 1.10 & 0.95 & 0.00 & 8.13 & 332 \\
Altitude & 0.66 & 0.19 & 0.92 & 0.00 & 4.33 & 332 \\
Dist. from Coast & 0.87 & 0.91 & 0.12 & 0.45 & 1.00 & 383 \\
Ruggedness & 126.89 & 99.33 & 103.53 & 0.00 & 474.34 & 378 \\
\hline
\end{tabular}

Notes: Log Income per capita in 2000 (PPP 2005 US dollars). Engineering density measured by engineers per 100.000 male workers. Engineering density measured by engineers per 100.000 male workers, sub-national. Engineering density measured by engineers per 100.000 male workers, sub-national, scaled by national estimates of engineering stock. Population density is number of individuals per square kilometer in 1900. Pre-colonial population density measures the number of natives per square kilometer in 1492. Literacy share of the population that is literate in 1900. Literacy share of the population that is literate in 1900, sub-national. Railroad density measured as miles of track per 1000 square kilometers. Railroad density measured as miles of track per 1000 square kilometers, sub-national. South is a dummy variable for whether the US state is a Southern state according to the US census. Slavery is measured as a fraction of the population and is taken from Bergad (2008) and Nunn (2008). Lawyer density measured by lawyers per 100.000 individuals. Mining is total mining output in 1860 in hundred thousand dollars. Spain is a dummy for whether the country was a Spanish colony: Argentina, Chile, Mexico and Venezuela. Agriculture Suitability is an index of probability of cultivation given cultivable land, climate and soil composition, from Ramankutty, Foley and McSweeney (2002). Rivers captures the density of rivers as a share of land area derived from HydroSHEDS (USGS 2011). Temperature is a yearly average in degrees celsius; Altitude measures the elevation of the capital city of the state in kilometers; and Rainfall captures total yearly rainfall in meters, all are from Bruhn and Gallego (2011). Distance from the Coast from Gennaioli et al. 2013); Ruggedness of Terrain from Nunn \& Puga 2012). 
Table 2: Summary Statistics (County Level, US)

\begin{tabular}{lcccccc}
\hline Variable & mean & p50 & sd & min & max & obs \\
\hline Ln Income & 10.043 & 10.032 & 0.219 & 9.165 & 11.360 & 1905 \\
Engineers & 0.022 & 0.000 & 0.038 & 0.000 & 0.299 & 1905 \\
Patents & 0.453 & 0.274 & 0.602 & 0.000 & 6.041 & 1905 \\
Ln LGC distance & 0.176 & 0.281 & 0.683 & -5.450 & 1.765 & 1905 \\
Rainfall & 0.077 & 0.076 & 0.042 & 0.009 & 0.393 & 1905 \\
Altitude & 0.025 & 0.023 & 0.019 & 0.000 & 0.175 & 1905 \\
Ruggedness & 0.005 & 0.003 & 0.006 & 0.000 & 0.043 & 1905 \\
Distance to river & 0.017 & 0.014 & 0.014 & 0.000 & 0.141 & 1905 \\
Average Temperature & -0.002 & -0.006 & 0.061 & -0.160 & 0.188 & 1905 \\
Dist. from Coast & 0.027 & 0.023 & 0.020 & 0.000 & 0.102 & 1905 \\
Population Density & 0.003 & 0.001 & 0.049 & 0.000 & 2.055 & 1905 \\
Manufacturing GDP & 0.042 & 0.018 & 0.066 & 0.000 & 0.576 & 1905 \\
Slavery & 0.153 & 0.019 & 0.215 & 0.000 & 0.925 & 1905 \\
Farms per capita & 0.105 & 0.110 & 0.038 & 0.000 & 0.698 & 1905 \\
Railroads & 0.584 & 1.000 & 0.493 & 0.000 & 1.000 & 1905 \\
Literacy & 0.759 & 0.829 & 0.203 & 0.151 & 1.000 & 1905 \\
School Assistance 12-17 & 0.051 & 0.055 & 0.018 & 0.000 & 0.090 & 1905 \\
Educational Score & 0.073 & 0.073 & 0.019 & 0.035 & 0.168 & 1905 \\
Lawyers & 0.001 & 0.001 & 0.001 & 0.000 & 0.005 & 1905 \\
Physicians & 0.002 & 0.002 & 0.001 & 0.000 & 0.004 & 1905 \\
\hline
\end{tabular}

Notes: Log Income per capita in 2000. Engineering density measured by engineers per 100,000 male workers. Patents density measured by patents per 100 habitants. Dist. to LGC is distance to Land Grant College measured by distance between the near LGC and the county centroid. Population density is number of individuals per 100 square kilometers in 1880. Literacy share of the population that is literate in 1880. Secondary is share of 14-17 years olds who report that they are attending school. Tertiary is- percentage of workers who report completing one or more years of college. Farms per capita is the number of farms per capita retrieved from University of Virginia Library. Railroad is a identifier variable if the county has railroad. Slavery to county level is taken from Nunn (2008). Lawyer density measured by lawyers per 100.000 individuals. Physicians density measured by physicians per 100.000 individuals. Mining is total mining output in 1860 in hundred thousand dollars. Rivers captures the distance between the near river and the county. Rivers taken from HydroSHEDS (USGS 2011). Temperature is a yearly average in degrees celsius; Altitude measures the elevation of the capital city of the state in kilometers; and Rainfall captures total yearly rainfall in meters. Dist. to Coast is distance between the coast and the county centroid; Ruggedness of Terrain from Nunn \& Puga (2012). Manuf. Output is the manufacturing output per capita in 1880 taken from NHGIS. 
Table 3: Summary Regressions: Innovation Capacity (1900) vs Income per capita (2000) (National Level, Americas)

\begin{tabular}{lccccc}
\hline & $(1)$ & $(2)$ & $(3)$ & $(4)$ & $(5)$ \\
\hline Engineering & $0.9^{* * *}$ & $0.9^{* *}$ & $0.9^{* * *}$ & 0.7 & $0.9^{* * *}$ \\
& $(0.35)$ & $(0.36)$ & $(0.30)$ & $(0.61)$ & $(0.31)$ \\
Pop Density & & $0.06^{*}$ & & & $0.06^{* *}$ \\
& & $(0.03)$ & & & $(0.03)$ \\
Railroads & & & 0.2 & & $0.2^{*}$ \\
& & & $(0.16)$ & & $(0.14)$ \\
Literacy & & & & 0.2 & \\
& & & & $(0.41)$ & \\
\hline N & 273 & 248 & 273 & 273 & 248 \\
N Countries & 11 & 11 & 11 & 11 & 11 \\
$R^{2}$ & 0.82 & 0.82 & 0.88 & 0.83 & 0.88 \\
\hline
\end{tabular}

Notes: Dependent Variable is log subnational income per capita (2000). Engineering density measured by engineers per 100,000 male workers. Population density is number of individuals per square kilometer in 1900. Railroad density measured as miles of track per 1000 square kilometers. Literacy share of the population that is literate in 1900. Beta coefficients. Robust and clustered SE in parenthesis. ${ }^{*} p<0.1,{ }^{* *} p<0.05,{ }^{* * *} p<0.01$. 
Table 4: Engineering Capacity as a Determinant of Income (County Level, US)

\begin{tabular}{|c|c|c|c|c|c|c|c|c|}
\hline & $\begin{array}{c}(1) \\
\text { OLS }\end{array}$ & $\begin{array}{c}(2) \\
\text { OLS }\end{array}$ & $\begin{array}{c}(3) \\
\text { OLS }\end{array}$ & $\begin{array}{c}(4) \\
\text { OLS }\end{array}$ & $\begin{array}{c}(5) \\
\text { OLS }\end{array}$ & $\begin{array}{c}(6) \\
\text { OLS }\end{array}$ & $\begin{array}{c}(7) \\
\text { OLS }\end{array}$ & $\begin{array}{c}(8) \\
\text { OLS }\end{array}$ \\
\hline \multirow[t]{2}{*}{ Engineers } & $0.224^{* * *}$ & $0.288^{* * *}$ & $0.190^{* * *}$ & $0.148^{* * *}$ & $0.184^{* * *}$ & $0.126^{* * *}$ & $0.117^{* * *}$ & $0.0931^{* * *}$ \\
\hline & $(0.0335)$ & $(0.0403)$ & $(0.0350)$ & $(0.0287)$ & $(0.0329)$ & $(0.0284)$ & $(0.0269)$ & $(0.0248)$ \\
\hline \multirow[t]{2}{*}{ Rainfall } & 0.0263 & 0.0332 & 0.0298 & 0.0553 & 0.0290 & 0.0720 & 0.0816 & 0.135 \\
\hline & $(0.0646)$ & $(0.0741)$ & $(0.0695)$ & $(0.0707)$ & $(0.0700)$ & $(0.0640)$ & $(0.0713)$ & $(0.0807)$ \\
\hline \multirow[t]{2}{*}{ Altitude } & -0.00452 & -0.0183 & 0.0347 & 0.00555 & 0.0425 & 0.0186 & -0.00955 & -0.0698 \\
\hline & $(0.0323)$ & $(0.0758)$ & $(0.0730)$ & $(0.0784)$ & $(0.0737)$ & $(0.0714)$ & $(0.0747)$ & $(0.0691)$ \\
\hline \multirow[t]{2}{*}{ Ruggedness } & -0.0810 & -0.0825 & -0.104 & -0.0298 & -0.115 & -0.0770 & -0.0335 & -0.0204 \\
\hline & $(0.0828)$ & $(0.106)$ & $(0.0911)$ & $(0.0850)$ & $(0.0894)$ & $(0.0783)$ & $(0.0788)$ & $(0.0775)$ \\
\hline \multirow[t]{2}{*}{ River Dist. } & 0.0234 & 0.0142 & 0.0210 & 0.0181 & 0.0183 & 0.0329 & 0.0282 & 0.0291 \\
\hline & $(0.0323)$ & $(0.0311)$ & $(0.0296)$ & $(0.0271)$ & $(0.0285)$ & $(0.0286)$ & $(0.0268)$ & $(0.0278)$ \\
\hline \multirow[t]{2}{*}{ Temperature } & $-0.281^{* * *}$ & $-0.311^{* * *}$ & $-0.122^{*}$ & -0.0101 & -0.0787 & $-0.120^{*}$ & -0.0314 & -0.0750 \\
\hline & $(0.0492)$ & $(0.0501)$ & $(0.0624)$ & $(0.0534)$ & $(0.0661)$ & $(0.0663)$ & $(0.0658)$ & $(0.134)$ \\
\hline \multirow[t]{2}{*}{ Coast Dist. } & $-0.172^{* * *}$ & $-0.237 * * *$ & $-0.171^{* * *}$ & $-0.130^{* *}$ & $-0.175^{* * *}$ & $-0.185^{* * *}$ & $-0.135 * * *$ & -0.0730 \\
\hline & $(0.0556)$ & $(0.0489)$ & $(0.0473)$ & $(0.0527)$ & $(0.0479)$ & $(0.0467)$ & $(0.0483)$ & $(0.0895)$ \\
\hline \multirow[t]{2}{*}{ Pop. Density } & & & $0.0930^{* * *}$ & $0.0952^{* * *}$ & $0.0934^{* * *}$ & $0.0830^{* * *}$ & $0.0895^{* * *}$ & $0.0993^{* * *}$ \\
\hline & & & $(0.00725)$ & $(0.00671)$ & $(0.00735)$ & $(0.00882)$ & $(0.00780)$ & $(0.00832)$ \\
\hline \multirow[t]{2}{*}{ Manuf. Output } & & & $0.197^{* * *}$ & $0.176^{* * *}$ & $0.213^{* * *}$ & $0.185^{* * *}$ & $0.171^{* * *}$ & $0.120^{* * *}$ \\
\hline & & & $(0.0443)$ & $(0.0395)$ & $(0.0430)$ & $(0.0446)$ & $(0.0416)$ & $(0.0386)$ \\
\hline \multirow[t]{2}{*}{ Slavery } & & & -0.1000 & 0.180 & -0.0418 & -0.0149 & 0.163 & $0.178^{* *}$ \\
\hline & & & $(0.0757)$ & $(0.109)$ & $(0.0770)$ & $(0.0840)$ & $(0.109)$ & $(0.0681)$ \\
\hline \multirow[t]{2}{*}{ Railroad } & & & $0.162^{* * *}$ & $0.113^{* * *}$ & $0.144^{* * *}$ & $0.131^{* * *}$ & $0.110^{* * *}$ & $0.0949^{* * *}$ \\
\hline & & & $(0.0343)$ & $(0.0320)$ & $(0.0327)$ & $(0.0313)$ & $(0.0306)$ & $(0.0197)$ \\
\hline \multirow[t]{2}{*}{ Farms per capita } & & & 0.0100 & 0.00698 & 0.00230 & 0.0401 & 0.0259 & -0.00261 \\
\hline & & & $(0.0616)$ & $(0.0441)$ & $(0.0589)$ & $(0.0596)$ & $(0.0475)$ & $(0.0349)$ \\
\hline \multirow[t]{2}{*}{ Literacy } & & & & $0.462^{* * *}$ & & & $0.393^{* * *}$ & $0.502^{* * *}$ \\
\hline & & & & $(0.103)$ & & & $(0.104)$ & $(0.0723)$ \\
\hline \multirow[t]{2}{*}{ Secondary } & & & & & $0.119^{* *}$ & & 0.00151 & 0.0361 \\
\hline & & & & & $(0.0516)$ & & $(0.0529)$ & $(0.0486)$ \\
\hline \multirow[t]{2}{*}{ Tertiary } & & & & & & $0.143^{* * *}$ & 0.0481 & 0.0572 \\
\hline & & & & & & $(0.0524)$ & $(0.0434)$ & $(0.0398)$ \\
\hline \multirow[t]{2}{*}{ Lawyers } & & & & & & $0.136^{* * *}$ & $0.115^{* * *}$ & $0.119^{* * *}$ \\
\hline & & & & & & $(0.0389)$ & $(0.0371)$ & $(0.0343)$ \\
\hline \multirow[t]{2}{*}{ Physicians } & & & & & & -0.00169 & -0.0464 & 0.0181 \\
\hline & & & & & & $(0.0438)$ & $(0.0396)$ & $(0.0301)$ \\
\hline Observations & 2,380 & 1,904 & 1,904 & 1,904 & 1,904 & 1,904 & 1,904 & 1,904 \\
\hline R-squared & 0.192 & 0.241 & 0.318 & 0.366 & 0.323 & 0.351 & 0.377 & 0.490 \\
\hline $\mathrm{FE}$ & No & No & No & No & No & No & No & Yes \\
\hline
\end{tabular}

Notes: Dependent Variable is log subnational income per capita (2000). Engineering density measured by engineers per 100,000 male workers. Patents density measured by patents per 100 inhabitants. Rainfall captures total yearly rainfall in meters; Altitude measures the elevation of the capital city of the state in kilometers; Ruggedness of Terrain from Nunn \& Puga (2012); Rivers captures the distance between the near river and the county. Rivers taken from HydroSHEDS (USGS 2011). Temperature is a yearly average in degrees Celsius; Dist. to Coast is distance between the coast and the county centroid. Population density is number of individuals per 100 square kilometers in 1880. Manuf. Output is the manufacturing output per capita in 1880 taken from NHGIS. Slavery to county level is taken from Nunn (2008). Farms per capita is the number of farms per capita retrieved from University of Virginia Library. Railroad is a identifier variable if the county has railroad. Literacy is share of the population that is literate in 1880. Secondary is share of 14-17 years olds who report that they are attending school. Tertiary is percentage of workers who report completing one or more years of college. Lawyer and Physician density measured per 100 individuals. Beta coefficients. Robust and clustered SE in parenthesis. ${ }^{*} p<0.1,{ }^{* *} p<0.05,{ }^{* * *} p<0.01$. 
Table 5: Engineering and Patenting Capacity as Determinants of Income: Patents \& IV (County Level, US)

\begin{tabular}{|c|c|c|c|c|c|c|}
\hline & $\begin{array}{l}(1) \\
\text { OLS }\end{array}$ & $\begin{array}{l}(2) \\
\text { OLS }\end{array}$ & $\begin{array}{c}(3) \\
\text { OLS }\end{array}$ & $\begin{array}{l}(4) \\
\text { OLS }\end{array}$ & $\begin{array}{l}\text { (5) } \\
\text { IV }\end{array}$ & $\begin{array}{c}(6) \\
\text { Buchinsky }\end{array}$ \\
\hline Engineers & & & $\begin{array}{c}0.0989^{* * *} \\
(0.0257)\end{array}$ & $\begin{array}{c}0.0789^{* * * *} \\
(0.0228)\end{array}$ & $\begin{array}{c}0.112^{* * *} \\
(0.0255)\end{array}$ & $\begin{array}{c}0.158^{* * *} \\
(0.0397)\end{array}$ \\
\hline Patents & $\begin{array}{c}0.137^{* * *} \\
(0.0383)\end{array}$ & $\begin{array}{c}0.127^{* * *} \\
(0.0363)\end{array}$ & $\begin{array}{l}0.116^{* * *} \\
(0.0377)\end{array}$ & $\begin{array}{c}0.113^{* * *} \\
(0.0353)\end{array}$ & $\begin{array}{c}0.131^{* * *} \\
(0.0360)\end{array}$ & $\begin{array}{c}0.109^{* * *} \\
(0.0368)\end{array}$ \\
\hline Rainfall & $\begin{array}{c}0.0864 \\
(0.0754)\end{array}$ & $\begin{array}{c}0.149^{*} \\
(0.0856)\end{array}$ & $\begin{array}{c}0.0804 \\
(0.0743)\end{array}$ & $\begin{array}{c}0.149^{*} \\
(0.0832)\end{array}$ & $\begin{array}{c}0.153^{*} \\
(0.0829)\end{array}$ & $\begin{array}{c}0.151^{*} \\
(0.0808)\end{array}$ \\
\hline Altitude & $\begin{array}{c}-0.0394 \\
(0.0736)\end{array}$ & $\begin{array}{l}-0.0990 \\
(0.0635)\end{array}$ & $\begin{array}{c}-0.0371 \\
(0.0749)\end{array}$ & $\begin{array}{c}-0.0952 \\
(0.0662)\end{array}$ & $\begin{array}{c}-0.108^{* *} \\
(0.0547)\end{array}$ & $\begin{array}{l}-0.0891 \\
(0.0610)\end{array}$ \\
\hline Ruggedness & $\begin{array}{c}-0.000979 \\
(0.0755)\end{array}$ & $\begin{array}{l}0.00261 \\
(0.0695)\end{array}$ & $\begin{array}{r}-0.00915 \\
(0.0773)\end{array}$ & $\begin{array}{c}-0.000504 \\
(0.0732)\end{array}$ & $\begin{array}{r}-0.00560 \\
(0.0669)\end{array}$ & $\begin{array}{l}2.61 \mathrm{e}-05 \\
(0.0679)\end{array}$ \\
\hline River Dist. & $\begin{array}{c}0.0295 \\
(0.0267)\end{array}$ & $\begin{array}{c}0.0267 \\
(0.0265)\end{array}$ & $\begin{array}{c}0.0254 \\
(0.0254)\end{array}$ & $\begin{array}{c}0.0247 \\
(0.0260)\end{array}$ & $\begin{array}{c}0.0315 \\
(0.0272)\end{array}$ & $\begin{array}{c}0.0281 \\
(0.0271)\end{array}$ \\
\hline Temperature & $\begin{array}{l}-0.0306 \\
(0.0654)\end{array}$ & $\begin{array}{c}-0.0817 \\
(0.131)\end{array}$ & $\begin{array}{c}-0.0368 \\
(0.0624)\end{array}$ & $\begin{array}{c}-0.0809 \\
(0.129)\end{array}$ & $\begin{array}{r}-0.0690 \\
(0.151)\end{array}$ & $\begin{array}{c}-0.0817 \\
(0.145)\end{array}$ \\
\hline Coast Dist. & $\begin{array}{c}-0.120^{* *} \\
(0.0501)\end{array}$ & $\begin{array}{l}-0.0510 \\
(0.0844)\end{array}$ & $\begin{array}{c}-0.124^{* *} \\
(0.0496)\end{array}$ & $\begin{array}{l}-0.0498 \\
(0.0841)\end{array}$ & $\begin{array}{l}-0.0372 \\
(0.0846)\end{array}$ & $\begin{array}{l}-0.0743 \\
(0.0786)\end{array}$ \\
\hline Pop. Density & $\begin{array}{c}0.0888^{* * *} * \\
(0.00738)\end{array}$ & $\begin{array}{c}0.0985^{* * *} \\
(0.00784)\end{array}$ & $\begin{array}{c}0.0889^{* * *} \\
(0.00774)\end{array}$ & $\begin{array}{c}0.0985^{* * *} \\
(0.00818)\end{array}$ & $\begin{array}{c}0.0949 * * * \\
(0.00834)\end{array}$ & $\begin{array}{l}0.102^{* * *} \\
(0.00795)\end{array}$ \\
\hline Manuf. Output & $\begin{array}{l}0.128^{* *} \\
(0.0489)\end{array}$ & $\begin{array}{c}0.0719 \\
(0.0439)\end{array}$ & $\begin{array}{l}0.123^{* *} \\
(0.0471)\end{array}$ & $\begin{array}{l}0.0695^{*} \\
(0.0408)\end{array}$ & $\begin{array}{c}0.0632 \\
(0.0452)\end{array}$ & $\begin{array}{c}0.0440 \\
(0.0443)\end{array}$ \\
\hline Slavery & $\begin{array}{c}0.176 \\
(0.114)\end{array}$ & $\begin{array}{l}0.188^{* *} \\
(0.0707)\end{array}$ & $\begin{array}{c}0.177 \\
(0.111)\end{array}$ & $\begin{array}{c}0.193 * * * \\
(0.0688)\end{array}$ & $\begin{array}{l}0.172^{* *} \\
(0.0693)\end{array}$ & $\begin{array}{l}0.167^{* *} \\
(0.0707)\end{array}$ \\
\hline Railroad & $\begin{array}{c}0.117 * * * \\
(0.0304)\end{array}$ & $\begin{array}{c}0.103^{* * *} \\
(0.0200)\end{array}$ & $\begin{array}{c}0.119 * * * \\
(0.0302)\end{array}$ & $\begin{array}{c}0.103^{* * *} \\
(0.0196)\end{array}$ & $\begin{array}{c}0.0880^{* * *} \\
(0.0189)\end{array}$ & $\begin{array}{c}0.0765^{* * *} \\
(0.0206)\end{array}$ \\
\hline Farms per capita & $\begin{array}{c}0.000461 \\
(0.0476)\end{array}$ & $\begin{array}{l}-0.0221 \\
(0.0352)\end{array}$ & $\begin{array}{c}0.0275 \\
(0.0481)\end{array}$ & $\begin{array}{r}-0.00204 \\
(0.0348)\end{array}$ & $\begin{array}{l}-0.0315 \\
(0.0318)\end{array}$ & $\begin{array}{l}0.000307 \\
(0.0365)\end{array}$ \\
\hline Literacy & $\begin{array}{c}0.409^{* * *} \\
(0.107)\end{array}$ & $\begin{array}{c}0.516^{* * *} \\
(0.0726)\end{array}$ & $\begin{array}{c}0.399^{* * *} \\
(0.107)\end{array}$ & $\begin{array}{c}0.518^{* * *} \\
(0.0732)\end{array}$ & $\begin{array}{c}0.514^{* * *} \\
(0.0718)\end{array}$ & $\begin{array}{c}0.508^{* * *} \\
(0.0706)\end{array}$ \\
\hline Secondary & $\begin{array}{c}0.0142 \\
(0.0540)\end{array}$ & $\begin{array}{c}0.0484 \\
(0.0494)\end{array}$ & $\begin{array}{c}0.0115 \\
(0.0531)\end{array}$ & $\begin{array}{c}0.0472 \\
(0.0488)\end{array}$ & $\begin{array}{c}0.0341 \\
(0.0539)\end{array}$ & $\begin{array}{c}0.0443 \\
(0.0504)\end{array}$ \\
\hline Tertiary & $\begin{array}{c}0.0324 \\
(0.0416)\end{array}$ & $\begin{array}{c}0.0437 \\
(0.0379)\end{array}$ & $\begin{array}{c}0.0251 \\
(0.0425)\end{array}$ & $\begin{array}{c}0.0383 \\
(0.0383)\end{array}$ & $\begin{array}{c}0.0399 \\
(0.0360)\end{array}$ & $\begin{array}{c}0.0239 \\
(0.0381)\end{array}$ \\
\hline Lawyers & $\begin{array}{c}0.112^{* * * *} \\
(0.0399)\end{array}$ & $\begin{array}{c}0.113^{* * *} \\
(0.0366)\end{array}$ & $\begin{array}{c}0.0937^{* *} \\
(0.0385)\end{array}$ & $\begin{array}{c}0.0980^{* * *} \\
(0.0350)\end{array}$ & $\begin{array}{c}0.106^{* * *} \\
(0.0389)\end{array}$ & $\begin{array}{c}0.102^{* * *} \\
(0.0348)\end{array}$ \\
\hline Physicians & $\begin{array}{l}-0.0493 \\
(0.0390)\end{array}$ & $\begin{array}{c}0.0166 \\
(0.0299)\end{array}$ & $\begin{array}{l}-0.0440 \\
(0.0383)\end{array}$ & $\begin{array}{c}0.0162 \\
(0.0298)\end{array}$ & $\begin{array}{c}0.0146 \\
(0.0293)\end{array}$ & $\begin{array}{c}0.0155 \\
(0.0316)\end{array}$ \\
\hline Observations & 1,904 & 1,904 & 1,904 & 1,904 & 1,904 & 1,904 \\
\hline $\begin{array}{l}\text { R-squared } \\
\text { FE }\end{array}$ & $\begin{array}{c}0.377 \\
\text { No }\end{array}$ & $\begin{array}{c}0.492 \\
\text { Yes }\end{array}$ & $\begin{array}{c}0.383 \\
\text { No }\end{array}$ & $\begin{array}{c}0.496 \\
\text { Yes }\end{array}$ & Yes & Yes \\
\hline $\begin{array}{l}\text { F statistical (robust) } \\
\text { F Cragg-Donald }\end{array}$ & & & & & $\begin{array}{l}13.75 \\
19.99\end{array}$ & \\
\hline
\end{tabular}

Notes: Dependent Variable is log subnational income per capita (2000). Standardized Beta coefficients. Engineering density measured by engineers per 100,000 male workers. Patents density measured by patents per 100 inhabitants. Rainfall captures total yearly rainfall in meters; Altitude measures the elevation of the capital city of the state in kilometers; Ruggedness of Terrain from Nunn \& Puga (2012); Rivers captures the distance between the near river and the county. Rivers taken from HydroSHEDS (USGS 2011). Temperature is a yearly average in degrees Celsius; Dist. to Coast is distance between the coast and the county centroid. Population density is number of individuals per 100 square kilometers in 1880. Manuf. Output is the manufacturing output per capita in 1880 taken from NHGIS. Slavery to county level is taken from Nunn (2008). Farms per capita is the number of farms per capita retrieved from University of Virginia Library. Railroad is a identifier variable if the county has railroad. Literacy share of the population that is literate in 1880. Secondary is share of 14-17 years olds who report that they are attending school. Tertiary is percentage of workers who report completing one or more years of college. Lawyer and Physician density measured per 100 individuals. Engineers instrumented using log distance to nearest Land Grant College measured by distance between the near LGC and the county centroid, estimated by 2SLS and Buchinsky quantile 2SLS. Beta coefficients. Robust and clustered SE in parenthesis. ${ }^{*} p<0.1,{ }^{* *} p<0.05,{ }^{* * *} p<0.01$. In Column 5, F statistical of instrument's relevance is 13.75 with robust standard errors and 7.62 with robust and clustered to state level standard errors. Cragg-Donald F statistical is 19.99. Using quantile regression in Column 6 F statistical of instrument's relevance is 25.45 with robust standard errors. 
Table 6: Correlates of distance to Land Grand College (First Stage)

\begin{tabular}{lccc}
\hline \hline & Engineers & Lawyers & Physicians \\
\hline Distance LGC 1862 & $-0.103^{* * *}$ & $-3.18 \mathrm{e}-05$ & 0.0120 \\
& $(0.0370)$ & $(2.74 \mathrm{e}-05)$ & $(0.0417)$ \\
Observations & 1,905 & 1,905 & 1,905 \\
R-squared & 0.011 & 0.003 & 0.000 \\
\cline { 2 - 4 } & & & \\
Distance LGC 1890 & -0.0461 & $7.85 \mathrm{e}-06$ & 0.0344 \\
& $(0.0348)$ & $(2.74 \mathrm{e}-05)$ & $(0.0405)$ \\
Observations & 1,905 & 1,905 & 1,905 \\
R-squared & 0.002 & 0.000 & 0.001 \\
\hline \hline
\end{tabular}

Notes: Engineering density measured by engineers per 100,000 male workers. Lawyer and Physician density measured per 100 individuals. Distance LGC 1862 (1890) is the log of distance between the near Land Grand College in 1862 (1890) and the county centroid. Robust and clustered SE in parenthesis. ${ }^{*} p<0.1,{ }^{* *} p<0.05,{ }^{* * *} p<0.01$. 
Table 7: Innovative Capacity as a Determinant of Income (State Level, Americas)

\begin{tabular}{|c|c|c|c|c|c|c|}
\hline & (1) & $(2)$ & $(3)$ & (4) & (5) & (6) \\
\hline \multirow[t]{2}{*}{ Engineering } & $0.1^{* * *}$ & $0.1^{* * *}$ & $0.07^{* * *}$ & $0.10^{* * *}$ & $0.1^{* * *}$ & $0.05^{* *}$ \\
\hline & $(0.04)$ & $(0.03)$ & $(0.02)$ & $(0.03)$ & $(0.02)$ & $(0.02)$ \\
\hline \multirow[t]{2}{*}{ Pop Density } & & $0.07^{* *}$ & $0.06^{* * *}$ & & $0.1^{* * *}$ & $0.06^{* * *}$ \\
\hline & & $(0.03)$ & $(0.02)$ & & $(0.04)$ & $(0.01)$ \\
\hline \multirow[t]{2}{*}{ Literacy } & & & $0.4^{* * *}$ & & & $0.4^{* * *}$ \\
\hline & & & $(0.13)$ & & & $(0.10)$ \\
\hline \multirow[t]{2}{*}{ Area } & & & & -0.03 & 0.08 & -0.04 \\
\hline & & & & $(0.06)$ & $(0.05)$ & $(0.04)$ \\
\hline \multirow[t]{2}{*}{ Ruggedness } & & & & -0.03 & -0.06 & $-0.04^{*}$ \\
\hline & & & & $(0.05)$ & $(0.04)$ & $(0.02)$ \\
\hline \multirow[t]{2}{*}{ Rainfall } & & & & $-0.1^{*}$ & -0.1 & -0.09 \\
\hline & & & & $(0.06)$ & $(0.08)$ & $(0.06)$ \\
\hline \multirow[t]{2}{*}{ Altitude } & & & & -0.03 & -0.07 & -0.03 \\
\hline & & & & $(0.05)$ & $(0.06)$ & $(0.05)$ \\
\hline \multirow[t]{2}{*}{ Landlocked } & & & & -0.02 & -0.003 & -0.02 \\
\hline & & & & $(0.03)$ & $(0.02)$ & $(0.04)$ \\
\hline \multirow[t]{2}{*}{ Constant } & 0.6 & 0.6 & $0.6^{* *}$ & 0.5 & 0.5 & $0.6^{* *}$ \\
\hline & $(0.42)$ & $(0.40)$ & $(0.28)$ & $(0.39)$ & $(0.37)$ & $(0.23)$ \\
\hline $\mathrm{N}$ & 170 & 166 & 166 & 160 & 156 & 156 \\
\hline N Countries & 6 & 6 & 6 & 6 & 6 & 6 \\
\hline$R^{2}$ & 0.11 & 0.18 & 0.37 & 0.19 & 0.29 & 0.48 \\
\hline
\end{tabular}

Notes: Dependent Variable is log subnational income per capita (2000). Data for Argentina, Chile, Colombia, Mexico, US and Venezuela. Engineering density measured by engineers per 100,000 male workers. Population density is log number of individuals per square kilometer in 1900. Literacy is share of the population that is literate in 1900. Beta coefficients. Bootstrapped clustered SE in parenthesis. ${ }^{*} p<0.1,{ }^{* *} p<0.05,{ }^{* * *} p<0.01$. 


\section{Table 8: Intermediate Mechanisms through which Engineering affects GDP (1930)}

\begin{tabular}{|c|c|c|c|c|c|}
\hline & $\begin{array}{c}\text { (1) } \\
\text { Value manuf. } \\
\text { per capita }\end{array}$ & $\begin{array}{c}(2) \\
\text { Horsepower } \\
\text { in manuf. }\end{array}$ & $\begin{array}{c}(3) \\
\text { Establishment } \\
\text { per capita }\end{array}$ & $\begin{array}{c}(4) \\
\text { Retail stores } \\
\text { per capita }\end{array}$ & $\begin{array}{c}(5) \\
\text { Wholesale sales } \\
\text { per capita }\end{array}$ \\
\hline Engineers & $\begin{array}{c}0.0688^{* *} \\
(0.0258)\end{array}$ & $\begin{array}{c}0.0464^{* *} \\
(0.0214)\end{array}$ & $\begin{array}{c}0.0611^{* *} \\
(0.0271)\end{array}$ & $\begin{array}{c}0.0794^{* *} \\
(0.0344)\end{array}$ & $\begin{array}{c}0.0937^{* * *} \\
(0.0298)\end{array}$ \\
\hline Rainfall & $\begin{array}{c}0.120 \\
(0.136)\end{array}$ & $\begin{array}{c}0.357^{* * *} \\
(0.106)\end{array}$ & $\begin{array}{l}0.0722 \\
(0.155)\end{array}$ & $\begin{array}{c}-0.0960 \\
(0.136)\end{array}$ & $\begin{array}{c}-0.127 \\
(0.0912)\end{array}$ \\
\hline Altitude & $\begin{array}{c}0.120^{*} \\
(0.0592)\end{array}$ & $\begin{array}{l}0.0837^{*} \\
(0.0465)\end{array}$ & $\begin{array}{l}0.156^{* *} \\
(0.0739)\end{array}$ & $\begin{array}{c}0.110 \\
(0.0854)\end{array}$ & $\begin{array}{l}0.136^{* *} \\
(0.0608)\end{array}$ \\
\hline Ruggedness & $\begin{array}{l}-0.113^{*} \\
(0.0657)\end{array}$ & $\begin{array}{c}0.0954^{* *} \\
(0.0444)\end{array}$ & $\begin{array}{l}-0.161^{*} \\
(0.0801)\end{array}$ & $\begin{array}{l}-0.141 \\
(0.106)\end{array}$ & $\begin{array}{l}-0.264^{* *} \\
(0.0998)\end{array}$ \\
\hline River Dist. & $\begin{array}{r}-0.00689 \\
(0.0201)\end{array}$ & $\begin{array}{l}-0.0422^{*} \\
(0.0222)\end{array}$ & $\begin{array}{c}0.0168 \\
(0.0248)\end{array}$ & $\begin{array}{c}0.0175 \\
(0.0229)\end{array}$ & $\begin{array}{c}0.0185 \\
(0.0236)\end{array}$ \\
\hline Temperature & $\begin{array}{l}0.0722 \\
(0.144)\end{array}$ & $\begin{array}{c}0.00190 \\
(0.135)\end{array}$ & $\begin{array}{c}0.257 \\
(0.174)\end{array}$ & $\begin{array}{l}0.257^{*} \\
(0.148)\end{array}$ & $\begin{array}{c}0.152 \\
(0.119)\end{array}$ \\
\hline Coast Dist. & $\begin{array}{c}-0.209^{* * *} \\
(0.0657)\end{array}$ & $\begin{array}{c}-0.128 \\
(0.0807)\end{array}$ & $\begin{array}{c}-0.334^{* * *} \\
(0.0903)\end{array}$ & $\begin{array}{c}-0.233^{* * *} \\
(0.0660)\end{array}$ & $\begin{array}{l}-0.0133 \\
(0.0923)\end{array}$ \\
\hline Pop. Density & $\begin{array}{c}-0.0439 * * * \\
(0.0128)\end{array}$ & $\begin{array}{c}-0.0998^{* * * *} \\
(0.0194)\end{array}$ & $\begin{array}{l}-0.00397 \\
(0.00937)\end{array}$ & $\begin{array}{c}-0.0378^{* * *} \\
(0.0122)\end{array}$ & $\begin{array}{c}0.0206^{* * *} \\
(0.00737)\end{array}$ \\
\hline Manuf. Output & $\begin{array}{l}0.296^{* * *} \\
(0.0471)\end{array}$ & $\begin{array}{c}0.243^{* * *} \\
(0.0394)\end{array}$ & $\begin{array}{l}0.254^{* * *} \\
(0.0472)\end{array}$ & $\begin{array}{l}0.155^{* * *} \\
(0.0471)\end{array}$ & $\begin{array}{l}0.207^{* * *} \\
(0.0411)\end{array}$ \\
\hline Slavery & $\begin{array}{c}-0.222^{\text {**** }} \\
(0.0387)\end{array}$ & $\begin{array}{l}-0.0139 \\
(0.0542)\end{array}$ & $\begin{array}{c}-0.498^{* * *} \\
(0.0455)\end{array}$ & $\begin{array}{c}-0.514^{* * *} \\
(0.0508)\end{array}$ & $\begin{array}{c}-0.206^{* * *} \\
(0.0520)\end{array}$ \\
\hline Railroad & $\begin{array}{c}0.0838^{* * *} \\
(0.0276)\end{array}$ & $\begin{array}{l}0.112^{* * *} \\
(0.0245)\end{array}$ & $\begin{array}{l}-0.0319 \\
(0.0358)\end{array}$ & $\begin{array}{l}-0.0540 \\
(0.0418)\end{array}$ & $\begin{array}{l}0.00231 \\
(0.0330)\end{array}$ \\
\hline Farms per capita & $\begin{array}{c}-0.0668^{*} \\
(0.0359)\end{array}$ & $\begin{array}{c}-0.0791^{* *} \\
(0.0337)\end{array}$ & $\begin{array}{c}-0.000692 \\
(0.0344)\end{array}$ & $\begin{array}{l}0.00544 \\
(0.0426)\end{array}$ & $\begin{array}{l}-0.102^{*} \\
(0.0600)\end{array}$ \\
\hline Literacy & $\begin{array}{c}0.0333 \\
(0.0630)\end{array}$ & $\begin{array}{c}0.0663 \\
(0.0534)\end{array}$ & $\begin{array}{l}-0.158^{*} \\
(0.0847)\end{array}$ & $\begin{array}{c}-0.199^{* *} \\
(0.0978)\end{array}$ & $\begin{array}{c}-0.116 \\
(0.0734)\end{array}$ \\
\hline Secondary & $\begin{array}{c}-0.176^{* * *} \\
(0.0409)\end{array}$ & $\begin{array}{c}-0.0923^{* *} \\
(0.0424)\end{array}$ & $\begin{array}{c}-0.189^{* * *} \\
(0.0502)\end{array}$ & $\begin{array}{c}-0.190^{* * *} \\
(0.0609)\end{array}$ & $\begin{array}{l}-0.129^{* *} \\
(0.0477)\end{array}$ \\
\hline Tertiary & $\begin{array}{c}0.128^{* * *} \\
(0.0354)\end{array}$ & $\begin{array}{c}0.0192 \\
(0.0340)\end{array}$ & $\begin{array}{l}0.137^{* *} \\
(0.0540)\end{array}$ & $\begin{array}{c}0.137^{* * *} \\
(0.0429)\end{array}$ & $\begin{array}{c}0.195^{* * *} \\
(0.0391)\end{array}$ \\
\hline Lawyers & $\begin{array}{c}0.173^{* * *} \\
(0.0365)\end{array}$ & $\begin{array}{l}-0.0204 \\
(0.0337)\end{array}$ & $\begin{array}{l}0.200^{* * *} \\
(0.0376)\end{array}$ & $\begin{array}{c}0.248^{* * *} \\
(0.0389)\end{array}$ & $\begin{array}{l}0.263^{* * *} \\
(0.0471)\end{array}$ \\
\hline Physicians & $\begin{array}{l}-0.0377 \\
(0.0343)\end{array}$ & $\begin{array}{l}-0.0277 \\
(0.0331)\end{array}$ & $\begin{array}{l}-0.0504 \\
(0.0365)\end{array}$ & $\begin{array}{l}-0.0665 \\
(0.0446)\end{array}$ & $\begin{array}{l}-0.0364 \\
(0.0402)\end{array}$ \\
\hline Observations & 1,745 & 1,722 & 1,745 & 1,884 & 1,761 \\
\hline R-squared & 0.490 & 0.514 & 0.486 & 0.470 & 0.419 \\
\hline $\mathrm{FE}$ & Yes & Yes & Yes & Yes & Yes \\
\hline
\end{tabular}

Notes: Dependent Variable is log of: Value of Manufactured Products (column 1), Horsepower in Manufacturing (rated capacity of prime movers of electric motors) (column 2), Manufacturing Establishments (column 3), Retail Distribution Stores (column 4) and Net Sales of Wholesale Establishments in Thousands of Dollars (column 5). Standardized Beta coefficients. Engineering density measured by engineers per 100,000 male workers. Patents density measured by patents per 100 inhabitants. Rainfall captures total yearly rainfall in meters; Altitude measures the elevation of the capital city of the state in kilometers; Ruggedness of Terrain from Nunn \& Puga (2012); Rivers captures the distance between the near river and the county. Rivers taken from HydroSHEDS (USGS 2011). Temperature is a yearly average in degrees Celsius; Dist. to Coast is distance between the coast and the county centroid. Population density is number of individuals per 100 square kilometers in 1880. Manuf. Output is the manufacturing output per capita in 1880 taken from NHGIS. Slavery to county level is taken from Nunn (2008). Railroad is a identifier variable if the county has railroad. Farms per capita is the number of farms per capita retrieved from University of Virginia Library. Literacy share of the population that is literate in 1880. Secondary is share of 14-17 years olds who report that they are attending school. Tertiary is percentage of workers who report completing one or more years of college. Lawyer and Physician density measured per 100 individuals. 
Table 9: Innovation Capacity Determinants (County Level)

\begin{tabular}{|c|c|c|c|c|}
\hline & \multicolumn{2}{|c|}{ Engineers } & \multicolumn{2}{|c|}{ Patents } \\
\hline & OLS & Buchinsky & OLS & Quantile \\
\hline & $(1)$ & $(2)$ & $(3)$ & $(4)$ \\
\hline \multirow[t]{2}{*}{ Pop. Density } & $0.02^{* * *}$ & $0.01^{* * *}$ & $0.3^{* * *}$ & $0.2^{* * *}$ \\
\hline & $(0.004)$ & $(0.002)$ & $(0.06)$ & $(0.02)$ \\
\hline \multirow[t]{2}{*}{ South } & $-0.02 * * *$ & -0.001 & $-0.2^{* * *}$ & $-0.2^{* * *}$ \\
\hline & $(0.004)$ & $(0.002)$ & $(0.05)$ & $(0.02)$ \\
\hline \multirow[t]{2}{*}{ Slavery } & $-0.02^{* * *}$ & $-0.009^{* *}$ & $-0.7^{* * *}$ & $-0.3^{* * *}$ \\
\hline & $(0.005)$ & $(0.004)$ & $(0.07)$ & $(0.05)$ \\
\hline \multirow[t]{2}{*}{ River distance } & -0.09 & -0.03 & -2.0 & -0.8 \\
\hline & $(0.08)$ & $(0.04)$ & $(1.3)$ & $(0.5)$ \\
\hline \multirow[t]{2}{*}{ Temperature } & $0.09 * * *$ & 0.02 & 0.3 & $0.4^{* *}$ \\
\hline & $(0.03)$ & $(0.01)$ & $(0.6)$ & $(0.2)$ \\
\hline \multirow[t]{2}{*}{ Rainfall } & $-0.08^{*}$ & -0.03 & $-1.2^{*}$ & $-1.3^{* * *}$ \\
\hline & $(0.04)$ & $(0.02)$ & $(0.7)$ & $(0.3)$ \\
\hline \multirow[t]{2}{*}{ Altitude } & -0.09 & -0.05 & $3.9^{*}$ & $2.4^{* * *}$ \\
\hline & $(0.10)$ & $(0.05)$ & $(2.1)$ & $(0.6)$ \\
\hline \multirow[t]{2}{*}{ Coast Distance } & -0.06 & 0.02 & $-4.7^{* * *}$ & $-0.8^{*}$ \\
\hline & $(0.06)$ & $(0.03)$ & $(0.9)$ & $(0.4)$ \\
\hline \multirow[t]{2}{*}{ Ruggedness } & $0.5^{*}$ & 0.2 & $-16.7^{* * *}$ & $-9.2^{* * *}$ \\
\hline & $(0.3)$ & $(0.1)$ & $(5.2)$ & $(1.9)$ \\
\hline $\mathrm{N}$ & 1912 & 1912 & 1907 & 1907 \\
\hline$R^{2}$ & 0.140 & & 0.231 & \\
\hline
\end{tabular}

Notes: Dependent Variable is innovative capacity measured by engineers per 100,000 male workers and patents per 100 inhabitants. Pre-colonial population density measures the number of natives per square kilometer in 1492. South a dummy capturing Southern US states; slavery as tabulated from the 1860 Census as compiled in Nunn (2008). Rainfall captures total yearly rainfall in meters; Altitude measures the elevation of the capital city of the state in kilometers; Ruggedness of Terrain from Nunn \& Puga (2012); Rivers captures the distance between the near river and the county. Rivers taken from HydroSHEDS (USGS 2011). Temperature is a yearly average in degrees celsius; Dist. to Coast is distance between the coast and the county centroid. Population density is number of individuals per 100 square kilometers in 1880. Geographical controls include river density, average temperature, rainfall, altitude, distance from a coast, and ruggedness of terrain. Robust SE in parenthesis. * $p<0.1,{ }^{* *} p<0.05,{ }^{* * *} p<0.01$. 
Table A1: Engineering Density as a Determinant of Patents (County Level, US)

\begin{tabular}{|c|c|c|c|c|c|c|c|}
\hline & $\begin{array}{c}(1) \\
\text { OLS }\end{array}$ & $\begin{array}{c}(2) \\
\text { OLS }\end{array}$ & $\begin{array}{c}(3) \\
\text { OLS }\end{array}$ & $\begin{array}{c}(4) \\
\text { OLS }\end{array}$ & $\begin{array}{c}(5) \\
\text { OLS }\end{array}$ & $\begin{array}{c}(6) \\
\text { OLS }\end{array}$ & $\begin{array}{c}(7) \\
\text { OLS }\end{array}$ \\
\hline Engineers & $\begin{array}{c}0.318^{* * *} \\
(0.0423)\end{array}$ & $\begin{array}{c}0.305^{* * *} \\
(0.0409)\end{array}$ & $\begin{array}{c}0.181^{* * *} \\
(0.0294)\end{array}$ & $\begin{array}{c}0.181^{* * *} \\
(0.0290)\end{array}$ & $\begin{array}{c}0.182^{* * *} \\
(0.0295)\end{array}$ & $\begin{array}{c}0.125^{* * *} \\
(0.0252)\end{array}$ & $\begin{array}{c}0.124^{* * *} \\
(0.0250)\end{array}$ \\
\hline Rainfall & & $\begin{array}{l}-0.181 \\
(0.155)\end{array}$ & $\begin{array}{l}-0.197 \\
(0.160)\end{array}$ & $\begin{array}{l}-0.196 \\
(0.162)\end{array}$ & $\begin{array}{l}-0.198 \\
(0.160)\end{array}$ & $\begin{array}{l}-0.142 \\
(0.138)\end{array}$ & $\begin{array}{l}-0.150 \\
(0.136)\end{array}$ \\
\hline Altitude & & $\begin{array}{l}0.206^{*} \\
(0.120)\end{array}$ & $\begin{array}{l}0.207^{* *} \\
(0.0921)\end{array}$ & $\begin{array}{l}0.207^{* *} \\
(0.0923)\end{array}$ & $\begin{array}{l}0.205^{* *} \\
(0.0926)\end{array}$ & $\begin{array}{l}0.212^{* *} \\
(0.0800)\end{array}$ & $\begin{array}{l}0.210^{* *} \\
(0.0773)\end{array}$ \\
\hline Ruggedness & & $\begin{array}{l}-0.179 \\
(0.118)\end{array}$ & $\begin{array}{c}-0.182^{*} \\
(0.103)\end{array}$ & $\begin{array}{c}-0.181^{*} \\
(0.101)\end{array}$ & $\begin{array}{c}-0.178^{*} \\
(0.103)\end{array}$ & $\begin{array}{l}-0.165^{*} \\
(0.0896)\end{array}$ & $\begin{array}{c}-0.173^{* *} \\
(0.0837)\end{array}$ \\
\hline River Dist. & & $\begin{array}{l}-0.0195 \\
(0.0469)\end{array}$ & $\begin{array}{c}0.0364 \\
(0.0361)\end{array}$ & $\begin{array}{c}0.0363 \\
(0.0363)\end{array}$ & $\begin{array}{c}0.0370 \\
(0.0364)\end{array}$ & $\begin{array}{c}0.0376 \\
(0.0324)\end{array}$ & $\begin{array}{c}0.0403 \\
(0.0324)\end{array}$ \\
\hline Temperature & & $\begin{array}{c}0.00860 \\
(0.168)\end{array}$ & $\begin{array}{c}0.00837 \\
(0.148)\end{array}$ & $\begin{array}{l}0.0113 \\
(0.148)\end{array}$ & $\begin{array}{c}-0.000773 \\
(0.147)\end{array}$ & $\begin{array}{c}0.0497 \\
(0.152)\end{array}$ & $\begin{array}{r}-0.0111 \\
(0.144)\end{array}$ \\
\hline Coast Dist. & & $\begin{array}{c}-0.238^{* *} \\
(0.0978)\end{array}$ & $\begin{array}{c}-0.175^{* *} \\
(0.0780)\end{array}$ & $\begin{array}{c}-0.175^{* *} \\
(0.0779)\end{array}$ & $\begin{array}{c}-0.172^{* *} \\
(0.0785)\end{array}$ & $\begin{array}{c}-0.203^{* * *} \\
(0.0733)\end{array}$ & $\begin{array}{c}-0.209^{* * *} * \\
(0.0750)\end{array}$ \\
\hline Pop. Density & & & $\begin{array}{l}0.0187^{* *} \\
(0.00827)\end{array}$ & $\begin{array}{l}0.0187^{* *} \\
(0.00828)\end{array}$ & $\begin{array}{l}0.0187 * * \\
(0.00829)\end{array}$ & $\begin{array}{c}0.0102 \\
(0.00726)\end{array}$ & $\begin{array}{c}0.00850 \\
(0.00722)\end{array}$ \\
\hline Manuf. Output & & & $\begin{array}{l}0.493^{* * *} \\
(0.0684)\end{array}$ & $\begin{array}{l}0.493^{* * *} \\
(0.0693)\end{array}$ & $\begin{array}{c}0.488^{* * *} \\
(0.0672)\end{array}$ & $\begin{array}{c}0.458^{* * *} \\
(0.0671)\end{array}$ & $\begin{array}{c}0.450 * * * \\
(0.0672)\end{array}$ \\
\hline Slavery & & & $\begin{array}{c}-0.0945^{* * *} \\
(0.0327)\end{array}$ & $\begin{array}{c}-0.0915^{* * *} \\
(0.0269)\end{array}$ & $\begin{array}{c}-0.106^{* * *} \\
(0.0299)\end{array}$ & $\begin{array}{c}-0.0713^{* *} \\
(0.0303)\end{array}$ & $\begin{array}{c}-0.140^{* * *} \\
(0.0319)\end{array}$ \\
\hline Farms per capita & & & $\begin{array}{l}-0.0595 \\
(0.0379)\end{array}$ & $\begin{array}{l}-0.0597 \\
(0.0385)\end{array}$ & $\begin{array}{l}-0.0540 \\
(0.0404)\end{array}$ & $\begin{array}{l}-0.0260 \\
(0.0325)\end{array}$ & $\begin{array}{r}-0.00967 \\
(0.0340)\end{array}$ \\
\hline Railroad & & & $\begin{array}{l}-0.0489 \\
(0.0332)\end{array}$ & $\begin{array}{l}-0.0495 \\
(0.0323)\end{array}$ & $\begin{array}{l}-0.0452 \\
(0.0320)\end{array}$ & $\begin{array}{c}-0.0804^{* *} \\
(0.0300)\end{array}$ & $\begin{array}{c}-0.0689^{* *} \\
(0.0293)\end{array}$ \\
\hline Literacy & & & & $\begin{array}{l}0.00750 \\
(0.0451)\end{array}$ & & & $\begin{array}{c}-0.141^{* *} \\
(0.0638)\end{array}$ \\
\hline Secondary & & & & & $\begin{array}{l}-0.0455 \\
(0.0400)\end{array}$ & & $\begin{array}{c}-0.0860^{* *} \\
(0.0353)\end{array}$ \\
\hline Tertiary & & & & & & $\begin{array}{c}0.130^{* * * *} \\
(0.0359)\end{array}$ & $\begin{array}{c}0.166^{* * *} \\
(0.0370)\end{array}$ \\
\hline Lawyers & & & & & & $\begin{array}{c}0.189 * * * \\
(0.0538)\end{array}$ & $\begin{array}{c}0.191^{* * *} \\
(0.0521)\end{array}$ \\
\hline Physicians & & & & & & $\begin{array}{r}-0.00601 \\
(0.0349)\end{array}$ & $\begin{array}{c}0.0171 \\
(0.0366)\end{array}$ \\
\hline Observations & 1,904 & 1,904 & 1,904 & 1,904 & 1,904 & 1,904 & 1,904 \\
\hline R-squared & 0.344 & 0.369 & 0.506 & 0.506 & 0.506 & 0.540 & 0.545 \\
\hline $\mathrm{FE}$ & Yes & Yes & Yes & Yes & Yes & Yes & Yes \\
\hline
\end{tabular}

Notes: Dependent Variable is patents per 100 inhabitants (1900). Engineering density measured by engineers per 100,000 male workers. Rainfall captures total yearly rainfall in meters; Altitude measures the elevation of the capital city of the state in kilometers; Ruggedness of Terrain from Nunn \& Puga 2012); Rivers captures the distance between the near river and the county. Rivers taken from HydroSHEDS (USGS 2011). Temperature is a yearly average in degrees Celsius; Dist. to Coast is distance between the const and the county centroid. Population density is number of individuals per 100 square kilometers in 1880 . Manuf. Output is the manufacturing output per capita in 1880 taken from NHGis. Sla of the population that is literate in 1880. Secondary is share of $14-17$ years olds who report that they are attending school. Tertiary is percentage of workers who report
completing one or more years of college. Lawyer and Physician density measured per 100 individuals. Robust and clustered SE in parenthesis. ${ }^{*} p<0.1,{ }^{* *} p<0.05$, *** $p<0.01$. 
Table A2: Innovative Capacity as a Determinant of Income (US)

\begin{tabular}{|c|c|c|c|c|c|c|c|}
\hline & (1) & $(2)$ & $(3)$ & $(4)$ & $(5)$ & $(6)$ & $(7)$ \\
\hline Engineering & $\begin{array}{c}0.06^{* * *} \\
(0.02)\end{array}$ & $\begin{array}{c}0.09^{* * *} \\
(0.02)\end{array}$ & $\begin{array}{c}0.05^{* * *} \\
(0.02)\end{array}$ & $\begin{array}{c}0.04^{* *} \\
(0.02)\end{array}$ & $\begin{array}{c}0.07^{* * *} \\
(0.01)\end{array}$ & $\begin{array}{c}0.1^{* * *} \\
(0.05)\end{array}$ & $\begin{array}{c}0.1^{* * * *} \\
(0.04)\end{array}$ \\
\hline Pop Density & & $\begin{array}{c}0.1^{* * *} \\
(0.03)\end{array}$ & & & & & $\begin{array}{l}-0.02 \\
(0.06)\end{array}$ \\
\hline Literacy & & & $\begin{array}{c}0.1^{*} \\
(0.06)\end{array}$ & & & & $\begin{array}{c}0.4 \\
(0.32)\end{array}$ \\
\hline Lawyers & & & & $\begin{array}{c}0.04 \\
(0.05)\end{array}$ & & & $\begin{array}{l}-0.05 \\
(0.05)\end{array}$ \\
\hline Railroads & & & & & $\begin{array}{c}0.1^{* * * *} \\
(0.02)\end{array}$ & & $\begin{array}{c}0.08 \\
(0.05)\end{array}$ \\
\hline Mining & & & & & $\begin{array}{l}-0.02 \\
(0.01)\end{array}$ & & $\begin{array}{c}-0.03^{* * *} \\
(0.01)\end{array}$ \\
\hline Slavery & & & & & & $\begin{array}{c}-0.004 \\
(0.06)\end{array}$ & $\begin{array}{c}0.2 \\
(0.14)\end{array}$ \\
\hline South & & & & & & $\begin{array}{r}-0.001 \\
(0.04)\end{array}$ & $\begin{array}{l}-0.02 \\
(0.03)\end{array}$ \\
\hline $\mathrm{N}$ & 51 & 51 & 51 & 51 & 44 & 38 & 34 \\
\hline$R^{2}$ & 0.14 & 0.40 & 0.17 & 0.17 & 0.47 & 0.41 & 0.60 \\
\hline
\end{tabular}

Notes: Dependent Variable is log subnational income per capita (2000). Engineering density measured by engineers per 100,000 male workers. Population density is log number of individuals per square kilometer in 1900. Literacy share of the population that is literate in 1900. Lawyer density measured by lawyers per 100.000 individuals. Institutional Controls: Slavery and South; Railroad density measured as miles of track per 1000 square kilometers. Mining is total mining output in 1880 in US 100,000 dollars. Beta coefficients. Robust SE in parenthesis. ${ }^{*} p<0.1,{ }^{* *} p<0.05,{ }^{* * *} p<0.01$. 
Table A3: Innovative Capacity as a Determinant of Income (US, instrumented)

\begin{tabular}{lccccc}
\hline & $(1)$ & $(2)$ & $(3)$ & $(4)$ & $(5)$ \\
\hline Engineering & $0.1^{* * *}$ & $0.1^{* * *}$ & $0.09^{* *}$ & $0.1^{* *}$ & $0.2^{* * *}$ \\
& $(0.03)$ & $(0.03)$ & $(0.04)$ & $(0.05)$ & $(0.07)$ \\
Pop Density & & $0.1^{* * *}$ & & & $0.2^{* * *}$ \\
& & $(0.03)$ & & & $(0.05)$ \\
Literacy & & & 0.08 & & -0.06 \\
& & & $(0.07)$ & & $(0.10)$ \\
Lawyers & & & & -0.005 & -0.05 \\
& & & & $(0.07)$ & $(0.05)$ \\
\hline $\mathrm{N}$ & 51 & 51 & 51 & 51 & 51 \\
$R^{2}$ & 0.02 & 0.29 & 0.12 & 0.01 & 0.11 \\
\hline
\end{tabular}

Notes: Dependent Variable is log subnational income per capita (2000). Engineering density measured by engineers per male workers. Population density is log number of individuals per square kilometer in 1900. Literacy share of the population that is literate in 1900. Lawyer density measured by lawyers per 100.000 individuals. Beta coefficients. Robust SE in parenthesis. * $p<0.1,{ }^{* *} p<0.05,{ }^{* * *} p<0.01 . R^{2}$ in specification 5 is close to 1 but not calculated. 
Table A4: Heterogeneity of Impact of Engineering across Agriculture and Lawyers

\begin{tabular}{|c|c|c|c|c|c|c|c|c|c|c|c|c|}
\hline & (1) & (2) & (3) & (4) & (5) & (6) & (7) & (8) & (9) & (10) & (11) & (12) \\
\hline & \multicolumn{6}{|c|}{ Lawyers } & \multicolumn{6}{|c|}{ Agriculture } \\
\hline & \multicolumn{3}{|c|}{ Below } & \multicolumn{3}{|c|}{ Above } & \multicolumn{3}{|c|}{ Below } & \multicolumn{3}{|c|}{ Above } \\
\hline & OLS & IV & Buchinsky & OLS & IV & Buchinsky & OLS & IV & Buchinsky & OLS & IV & Buchinsky \\
\hline \multirow[t]{2}{*}{ Engineers } & $0.0932^{* *}$ & $0.0870^{* *}$ & 0.0243 & $0.0647 * * *$ & $0.110^{* * *}$ & $0.217^{* * *}$ & $0.0961^{* * *}$ & $0.115^{* * *}$ & $0.173^{* * *}$ & 0.00567 & 0.0347 & -0.0275 \\
\hline & $(0.0390)$ & $(0.0381)$ & $(0.0328)$ & $(0.0236)$ & $(0.0330)$ & $(0.0562)$ & $(0.0267)$ & $(0.0421)$ & $(0.0423)$ & $(0.0214)$ & $(0.0332)$ & $(0.0266)$ \\
\hline \multirow[t]{2}{*}{ Rainfall } & 0.0470 & 0.0579 & 0.0522 & 0.131 & 0.135 & 0.140 & $0.178^{*}$ & $0.143^{*}$ & $0.158^{* *}$ & 0.0434 & 0.0615 & 0.0518 \\
\hline & $(0.137)$ & $(0.128)$ & $(0.131)$ & $(0.0959)$ & $(0.102)$ & $(0.0988)$ & $(0.0907)$ & $(0.0799)$ & $(0.0768)$ & $(0.0840)$ & $(0.105)$ & $(0.104)$ \\
\hline \multirow[t]{2}{*}{ Altitude } & 0.0549 & 0.0373 & 0.0583 & $-0.161^{* *}$ & $-0.168^{* * *}$ & $-0.146^{* *}$ & $-0.146^{* *}$ & $-0.143^{* * *}$ & $-0.132^{* *}$ & 0.0928 & 0.0853 & 0.0934 \\
\hline & $(0.0679)$ & $(0.0712)$ & $(0.0692)$ & $(0.0605)$ & $(0.0546)$ & $(0.0587)$ & $(0.0569)$ & $(0.0447)$ & $(0.0536)$ & $(0.0729)$ & $(0.0705)$ & $(0.0738)$ \\
\hline \multirow[t]{2}{*}{ Ruggedness } & -0.0607 & -0.0637 & -0.0606 & 0.0124 & 0.00723 & 0.00202 & 0.0323 & 0.0212 & 0.0355 & -0.0767 & -0.0917 & -0.0868 \\
\hline & $(0.0824)$ & $(0.0879)$ & $(0.0854)$ & $(0.106)$ & $(0.103)$ & $(0.103)$ & $(0.101)$ & $(0.0869)$ & $(0.0807)$ & $(0.0635)$ & $(0.0752)$ & $(0.0748)$ \\
\hline \multirow[t]{2}{*}{ River Dist. } & 0.0215 & 0.0341 & 0.0262 & 0.00922 & 0.00947 & 0.0124 & 0.0313 & 0.0395 & 0.0368 & 0.00927 & 0.0119 & 0.0103 \\
\hline & $(0.0398)$ & $(0.0445)$ & $(0.0436)$ & $(0.0283)$ & $(0.0278)$ & $(0.0294)$ & $(0.0400)$ & $(0.0397)$ & $(0.0396)$ & $(0.0264)$ & $(0.0287)$ & $(0.0293)$ \\
\hline \multirow[t]{2}{*}{ Temperature } & -0.0335 & -0.0259 & -0.0459 & -0.143 & -0.132 & -0.122 & -0.0638 & -0.0361 & -0.0214 & -0.0635 & -0.0676 & -0.0755 \\
\hline & $(0.211)$ & $(0.204)$ & $(0.215)$ & $(0.120)$ & $(0.125)$ & $(0.105)$ & $(0.179)$ & $(0.156)$ & $(0.152)$ & $(0.128)$ & $(0.145)$ & $(0.150)$ \\
\hline \multirow[t]{2}{*}{ Coast Dist. } & -0.182 & -0.166 & $-0.187^{*}$ & -0.00269 & 0.0109 & -0.0318 & -0.125 & -0.0914 & -0.110 & -0.0826 & -0.0871 & -0.0995 \\
\hline & $(0.114)$ & $(0.104)$ & $(0.105)$ & $(0.0751)$ & $(0.0862)$ & $(0.0748)$ & $(0.110)$ & $(0.0774)$ & $(0.0766)$ & $(0.0923)$ & $(0.110)$ & $(0.114)$ \\
\hline \multirow[t]{2}{*}{ Pop. Density } & $6.653^{*}$ & $0.179^{* *}$ & $0.185^{*}$ & $0.0973^{* * *}$ & $0.135^{* * *}$ & $0.147^{* * * *}$ & $0.0871^{* * *}$ & $0.107^{* * *}$ & $0.115^{* * *}$ & $25.57^{* * *}$ & $0.339^{* * *}$ & $0.363^{* * * *}$ \\
\hline & (3.439) & $(0.0890)$ & $(0.0966)$ & $(0.0103)$ & $(0.0151)$ & $(0.0144)$ & $(0.0115)$ & $(0.0146)$ & $(0.0136)$ & $(4.853)$ & $(0.0650)$ & $(0.0710)$ \\
\hline \multirow[t]{2}{*}{ Manuf. Output } & 0.0754 & 0.0589 & 0.0652 & 0.00545 & 0.0114 & -0.0307 & 0.0285 & 0.0193 & 0.00190 & $0.166^{* *}$ & $0.0729^{* *}$ & $0.0712^{* *}$ \\
\hline & $(0.0688)$ & $(0.0671)$ & $(0.0676)$ & $(0.0560)$ & $(0.0636)$ & $(0.0647)$ & $(0.0434)$ & $(0.0556)$ & $(0.0559)$ & $(0.0683)$ & $(0.0287)$ & $(0.0293)$ \\
\hline \multirow[t]{2}{*}{ Slavery } & $0.134^{*}$ & $0.135^{*}$ & $0.143^{*}$ & $0.354^{* * * *}$ & $0.261^{* * * *}$ & $0.252^{* * *}$ & $0.247^{* *}$ & $0.246^{* *}$ & $0.238^{* *}$ & $0.122^{*}$ & $0.105^{*}$ & $0.109^{*}$ \\
\hline & $(0.0671)$ & $(0.0786)$ & $(0.0793)$ & $(0.0723)$ & $(0.0543)$ & $(0.0610)$ & $(0.111)$ & $(0.120)$ & $(0.120)$ & $(0.0669)$ & $(0.0586)$ & $(0.0579)$ \\
\hline \multirow[t]{2}{*}{ Railroad } & $0.0633^{* *}$ & $0.0528^{*}$ & $0.0585^{* *}$ & $0.135^{* * *}$ & $0.128^{* * *}$ & $0.101^{* * *}$ & $0.116^{* * *}$ & $0.0845^{* * *}$ & $0.0670^{* * *}$ & $0.0592^{*}$ & $0.0675^{*}$ & $0.0734^{* *}$ \\
\hline & $(0.0243)$ & $(0.0272)$ & $(0.0260)$ & $(0.0291)$ & $(0.0268)$ & $(0.0285)$ & $(0.0299)$ & $(0.0237)$ & $(0.0249)$ & $(0.0292)$ & $(0.0358)$ & $(0.0347)$ \\
\hline \multirow[t]{2}{*}{ Farms per capita } & $0.0896^{*}$ & 0.0495 & 0.0594 & -0.0349 & -0.0651 & -0.0212 & -0.0241 & -0.0589 & -0.0227 & 0.0129 & 0.00840 & 0.00893 \\
\hline & $(0.0514)$ & $(0.0418)$ & $(0.0447)$ & $(0.0388)$ & $(0.0465)$ & $(0.0475)$ & $(0.0678)$ & $(0.0406)$ & $(0.0442)$ & $(0.0230)$ & $(0.0179)$ & $(0.0173)$ \\
\hline \multirow[t]{2}{*}{ Literacy } & $0.557^{* * *}$ & $0.574^{* * *}$ & $0.580^{* * *}$ & $0.445^{* * *}$ & $0.360^{* * *}$ & $0.340^{* * *}$ & $0.519^{* * *}$ & $0.516^{* * *}$ & $0.500^{* * *}$ & $0.324^{* * *}$ & $0.350^{* * *}$ & $0.347^{* * * *}$ \\
\hline & $(0.105)$ & $(0.108)$ & $(0.110)$ & $(0.0867)$ & $(0.0696)$ & $(0.0634)$ & $(0.141)$ & $(0.136)$ & $(0.131)$ & $(0.0666)$ & $(0.0694)$ & $(0.0710)$ \\
\hline \multirow[t]{2}{*}{ Secondary } & 0.0478 & 0.0393 & 0.0530 & 0.0131 & 0.00723 & 0.00457 & -0.00427 & -0.00890 & -0.00325 & 0.00596 & 0.00227 & 0.00673 \\
\hline & $(0.0629)$ & $(0.0728)$ & $(0.0683)$ & $(0.0559)$ & $(0.0495)$ & $(0.0483)$ & $(0.0705)$ & $(0.0649)$ & $(0.0625)$ & $(0.0449)$ & $(0.0512)$ & $(0.0516)$ \\
\hline Tertiary & -0.0130 & -0.00591 & -0.0107 & 0.0749 & 0.0624 & 0.0438 & 0.0392 & 0.0348 & 0.0157 & -0.0211 & -0.0222 & -0.0229 \\
\hline & $(0.0409)$ & $(0.0373)$ & $(0.0379)$ & $(0.0547)$ & $(0.0460)$ & $(0.0501)$ & $(0.0610)$ & $(0.0520)$ & $(0.0567)$ & $(0.0497)$ & $(0.0556)$ & $(0.0565)$ \\
\hline Lawyers & $0.206^{* * *}$ & $0.0865^{* * *}$ & $0.0915^{* * *}$ & $0.0803^{* *}$ & $0.0826^{* *}$ & $0.0809^{* *}$ & $0.200^{* * *}$ & $0.207^{* * *}$ & $0.207^{* * *}$ & -0.0292 & -0.0302 & -0.0287 \\
\hline & $(0.0727)$ & $(0.0334)$ & $(0.0325)$ & $(0.0391)$ & $(0.0372)$ & $(0.0349)$ & $(0.0525)$ & $(0.0552)$ & $(0.0484)$ & $(0.0360)$ & $(0.0375)$ & $(0.0384)$ \\
\hline Physicians & 0.0384 & 0.0503 & 0.0464 & 0.0137 & 0.00462 & 0.00571 & 0.0145 & 0.0102 & 0.0123 & -0.0187 & -0.0219 & -0.0240 \\
\hline & $(0.0457)$ & $(0.0421)$ & $(0.0431)$ & $(0.0325)$ & $(0.0313)$ & $(0.0345)$ & $(0.0543)$ & $(0.0478)$ & $(0.0479)$ & $(0.0376)$ & $(0.0464)$ & $(0.0464)$ \\
\hline Patents & -0.000642 & 0.0155 & 0.00390 & $0.156^{* * *}$ & $0.200^{* * *}$ & $0.176^{* * *}$ & $0.107^{* * *}$ & $0.140^{* * *}$ & $0.122^{* * *}$ & $0.182^{*}$ & $0.120^{*}$ & $0.122^{*}$ \\
\hline & $(0.0781)$ & $(0.0504)$ & $(0.0530)$ & $(0.0348)$ & $(0.0421)$ & $(0.0436)$ & $(0.0317)$ & $(0.0370)$ & $(0.0376)$ & $(0.0971)$ & $(0.0625)$ & $(0.0629)$ \\
\hline Constant & $0.439^{* * *}$ & $0.00996^{*}$ & $0.0110^{* *}$ & -0.0268 & $-0.0242^{* * *}$ & $-0.0190^{* * *}$ & -0.0802 & $-0.0238^{* * *}$ & $-0.0189 * * *$ & $1.175^{* * *}$ & $0.0191^{*}$ & $0.0207^{* *}$ \\
\hline & $(0.150)$ & $(0.00512)$ & $(0.00490)$ & $(0.0618)$ & $(0.00506)$ & $(0.00538)$ & $(0.0678)$ & $(0.00668)$ & $(0.00703)$ & $(0.240)$ & $(0.0101)$ & $(0.00980)$ \\
\hline Observations & 952 & 952 & 952 & 952 & 952 & 952 & 952 & 952 & 952 & 952 & 952 & 952 \\
\hline R-squared & 0.500 & & & 0.503 & & & 0.553 & & & 0.489 & & \\
\hline FE & Yes & Yes & Yes & Yes & Yes & Yes & Yes & Yes & Yes & Yes & Yes & Yes \\
\hline
\end{tabular}

Notes: Dependent Variable is log subnational income per capita (2000). Engineering density measured by engineers per 100,000 male workers. Patents density measured by patents per 100 inhabitants. Rainfall captures total yearly rainfall in meters; Altitude measures the elevation of the capital city of the state in kilometers; Ruggedness of Terrain from Nunn \& Puga (2012); Rivers captures the distance between the near river and the county. Rivers taken from HydroSHEDS (USGS 2011). Temperature is a yearly average in degrees Celsius; Dist. to Coast is distance between the coast and the county centroid. Population density is number of individuals per 100 square kilometers in 1880. Manuf. Output is the manufacturing output per capita in 1880 taken from NHGIS. Slavery to county level is taken from Nunn (2008). Farms per capita is the number of farms per capita retrieved from University of Virginia Library. Railroad is a identifier variable if the county has railroad. Literacy is share of the population that is literate in 1880. Secondary is share of 14-17 years olds who report that they are attending school. Tertiary is percentage of workers who report completing one or more years of college. Lawyer and Physician density measured per 100 individuals. To compute heterogeneous effects, Lawyers and Agriculture are divided by above and below the median. Beta coefficients. Robust and clustered SE in parenthesis. $p<0.1,{ }^{* *} p<0.05,{ }^{* * *} p<0.01$. 


\section{Table A5: Additional Controls for Religion and Immigration}

\begin{tabular}{|c|c|c|c|c|c|c|c|c|}
\hline & $\begin{array}{c}(1) \\
\text { OLS }\end{array}$ & $\begin{array}{c}(2) \\
\text { OLS }\end{array}$ & $\begin{array}{c}(3) \\
\text { OLS }\end{array}$ & $\begin{array}{c}(4) \\
\text { OLS }\end{array}$ & $\begin{array}{c}(5) \\
\text { OLS }\end{array}$ & $\begin{array}{c}(6) \\
\text { OLS }\end{array}$ & $\begin{array}{c}(7) \\
\text { OLS }\end{array}$ & $\begin{array}{c}(8) \\
\text { OLS }\end{array}$ \\
\hline \multirow[t]{2}{*}{ Engineers } & $0.223^{* * *}$ & $0.291^{* * *}$ & $0.156^{* * *}$ & $0.129^{* * *}$ & $0.150^{* * *}$ & $0.102^{* * *}$ & $0.103^{* * *}$ & $0.0866^{* * *}$ \\
\hline & $(0.0370)$ & $(0.0363)$ & $(0.0357)$ & $(0.0315)$ & $(0.0357)$ & $(0.0345)$ & $(0.0322)$ & $(0.0269)$ \\
\hline \multirow[t]{2}{*}{ Rainfall } & & 0.0116 & 0.0199 & 0.0403 & 0.0217 & 0.0538 & 0.0622 & $0.145^{*}$ \\
\hline & & $(0.0820)$ & $(0.0694)$ & $(0.0737)$ & $(0.0717)$ & $(0.0679)$ & $(0.0732)$ & $(0.0731)$ \\
\hline \multirow[t]{2}{*}{ Altitude } & & -0.0393 & -0.0200 & -0.0349 & -0.0232 & -0.0275 & -0.0382 & -0.0731 \\
\hline & & $(0.0940)$ & $(0.109)$ & $(0.109)$ & $(0.108)$ & $(0.104)$ & $(0.104)$ & $(0.0794)$ \\
\hline \multirow[t]{2}{*}{ Ruggedness } & & -0.0299 & -0.0364 & 0.0188 & -0.0400 & -0.0132 & 0.00642 & -0.0220 \\
\hline & & $(0.116)$ & $(0.108)$ & $(0.0950)$ & $(0.105)$ & $(0.0926)$ & $(0.0892)$ & $(0.0897)$ \\
\hline \multirow[t]{2}{*}{ River Dist. } & & 0.0229 & 0.0289 & 0.0186 & 0.0249 & 0.0364 & 0.0272 & 0.0290 \\
\hline & & $(0.0294)$ & $(0.0305)$ & $(0.0291)$ & $(0.0286)$ & $(0.0300)$ & $(0.0287)$ & $(0.0265)$ \\
\hline \multirow[t]{2}{*}{ Temperature } & & $-0.307^{* * *}$ & -0.0854 & 0.0105 & -0.0328 & -0.0692 & 0.00158 & 0.00253 \\
\hline & & $(0.0615)$ & $(0.0704)$ & $(0.0580)$ & $(0.0698)$ & $(0.0670)$ & $(0.0651)$ & $(0.154)$ \\
\hline \multirow[t]{2}{*}{ Coast Dist. } & & $-0.275^{* * *}$ & $-0.183^{* * *}$ & $-0.149^{* *}$ & $-0.179^{* * *}$ & $-0.195^{* * *}$ & $-0.154^{* * *}$ & -0.0615 \\
\hline & & $(0.0444)$ & $(0.0549)$ & $(0.0611)$ & $(0.0564)$ & $(0.0527)$ & $(0.0556)$ & $(0.0835)$ \\
\hline \multirow[t]{2}{*}{ Pop. Density } & & & $0.0898^{* * *}$ & $0.0930 * * *$ & $0.0893^{* * *}$ & $0.0800^{* * *}$ & $0.0873^{* * *}$ & $0.0937 * * *$ \\
\hline & & & $(0.00827)$ & $(0.00774)$ & $(0.00843)$ & $(0.0105)$ & $(0.00950)$ & $(0.0111)$ \\
\hline \multirow[t]{2}{*}{ Manuf. Output } & & & $0.161^{* * *}$ & $0.154^{* * *}$ & $0.180^{* * *}$ & $0.163^{* * *}$ & $0.160^{* * *}$ & $0.0996^{* *}$ \\
\hline & & & $(0.0543)$ & $(0.0478)$ & $(0.0525)$ & $(0.0527)$ & $(0.0492)$ & $(0.0464)$ \\
\hline \multirow[t]{2}{*}{ Slavery } & & & -0.115 & 0.130 & -0.0477 & -0.0243 & 0.128 & $0.182^{* *}$ \\
\hline & & & $(0.0752)$ & $(0.122)$ & $(0.0874)$ & $(0.0940)$ & $(0.125)$ & $(0.0707)$ \\
\hline \multirow[t]{2}{*}{ Railroad } & & & $0.140^{* * *}$ & $0.100^{* * *}$ & $0.128^{* * *}$ & $0.117^{* * *}$ & $0.0935^{* * *}$ & $0.0800 * * *$ \\
\hline & & & $(0.0348)$ & $(0.0325)$ & $(0.0331)$ & $(0.0323)$ & $(0.0313)$ & $(0.0204)$ \\
\hline \multirow[t]{2}{*}{ Farms per capita } & & & -0.0148 & -0.00504 & -0.0148 & 0.0345 & 0.0238 & 0.0241 \\
\hline & & & $(0.0613)$ & $(0.0499)$ & $(0.0607)$ & $(0.0588)$ & $(0.0537)$ & $(0.0457)$ \\
\hline \multirow[t]{2}{*}{ Churches per capita } & & & -0.0196 & -0.0190 & -0.0126 & -0.000975 & -0.00473 & -0.0207 \\
\hline & & & $(0.0443)$ & $(0.0343)$ & $(0.0433)$ & $(0.0386)$ & $(0.0346)$ & $(0.0248)$ \\
\hline \multirow[t]{2}{*}{ Foreigners per capita } & & & 0.0917 & 0.0662 & 0.111 & 0.107 & 0.0741 & 0.134 \\
\hline & & & $(0.0846)$ & $(0.0746)$ & $(0.0854)$ & $(0.0880)$ & $(0.0852)$ & $(0.0869)$ \\
\hline \multirow[t]{2}{*}{ Literacy } & & & & $0.406^{* * *}$ & & & $0.335 * * *$ & $0.500^{* * *}$ \\
\hline & & & & $(0.111)$ & & & $(0.108)$ & $(0.0808)$ \\
\hline \multirow[t]{2}{*}{ Secondary } & & & & & $0.127^{* *}$ & & 0.0231 & 0.0819 \\
\hline & & & & & $(0.0604)$ & & $(0.0622)$ & $(0.0570)$ \\
\hline \multirow[t]{2}{*}{ Tertiary } & & & & & & $0.119^{* *}$ & 0.0356 & 0.0696 \\
\hline & & & & & & $(0.0532)$ & $(0.0458)$ & $(0.0448)$ \\
\hline \multirow[t]{2}{*}{ Lawyers } & & & & & & $0.116^{* * *}$ & $0.111^{* * *}$ & $0.124^{* * *}$ \\
\hline & & & & & & $(0.0403)$ & $(0.0408)$ & $(0.0406)$ \\
\hline \multirow[t]{2}{*}{ Physicians } & & & & & & 0.0247 & -0.0297 & 0.0419 \\
\hline & & & & & & $(0.0539)$ & $(0.0484)$ & $(0.0320)$ \\
\hline Observations & 2,380 & 1,656 & 1,656 & 1,656 & 1,656 & 1,656 & 1,656 & 1,656 \\
\hline R-squared & 0.077 & 0.274 & 0.345 & 0.379 & 0.351 & 0.371 & 0.388 & 0.501 \\
\hline $\mathrm{FE}$ & No & No & No & No & No & No & No & Yes \\
\hline
\end{tabular}

Notes: Dependent Variable is log subnational income per capita (2000). Engineering density measured by engineers per 100,000 male workers. Patents density measured by patents per 100 inhabitants. Rainfall captures total yearly rainfall in meters; Altitude measures the elevation of the capital city of the state in kilometers; Ruggedness of Terrain from Nunn \& Puga (2012); Rivers captures the distance between the near river and the county. Rivers taken from HydroSHEDS (USGS 2011). Temperature is a yearly average in degrees Celsius; Dist. to Coast is distance between the coast and the county centroid. Population density is number of individuals per 100 square kilometers in 1880. Manuf. Output is the manufacturing output per capita in 1880 taken from NHGIS. Slavery to county level is taken from Nunn (2008). Farms per capita is the number of farms per capita retrieved from University of Virginia Library. Railroad is a identifier variable if the county has railroad. Foreigners is born people per capita taken from the 1880 census and University of Virginia Historical Census Browser (UVCB). Churches per capita at the county level, taken from the 1860 census. Literacy is share of the population that is literate in 1880. Secondary is share of 14-17 years olds who report that they are attending school. Tertiary is percentage of workers who report completing one or more years of college. Lawyer and Physician density measured per 100 individuals. Beta coefficients. Robust and clustered SE in parenthesis. ${ }^{*} p<0.1,{ }^{* *} p<0.05,{ }^{* * *} p<0.01$. 
Table A6: Innovation Capacity Determinants (County Level)

\begin{tabular}{lcccc}
\hline \multirow{2}{*}{ OLS } & Buchinsky & OLS & Quantile \\
\hline Pop. Density & $0.01^{* * *}$ & $0.01^{* * *}$ & $0.2^{* *}$ & $0.1^{* * *}$ \\
& $(0.004)$ & $(0.002)$ & $(0.07)$ & $(0.02)$ \\
South & $-0.010^{* * *}$ & 0.002 & $-0.1^{* *}$ & $-0.2^{* * *}$ \\
& $(0.004)$ & $(0.002)$ & $(0.06)$ & $(0.03)$ \\
Slavery & $-0.02^{* * *}$ & $-0.009^{* *}$ & $-0.6^{* * *}$ & $-0.3^{* * *}$ \\
& $(0.006)$ & $(0.004)$ & $(0.08)$ & $(0.05)$ \\
River distance & 0.02 & -0.02 & -0.3 & 0.06 \\
& $(0.09)$ & $(0.04)$ & $(1.3)$ & $(0.5)$ \\
Temperature & $0.1 * * *$ & 0.02 & $1.3^{*}$ & $0.7^{* * *}$ \\
& $(0.04)$ & $(0.02)$ & $(0.7)$ & $(0.2)$ \\
Rainfall & -0.04 & -0.005 & -0.6 & $-0.7^{* *}$ \\
\multirow{3}{*}{ Altitude } & $(0.06)$ & $(0.02)$ & $(0.8)$ & $(0.3)$ \\
Coast Distance & -0.2 & -0.07 & 1.3 & 0.9 \\
& $(0.1)$ & $(0.06)$ & $(2.7)$ & $(0.7)$ \\
Ruggedness & 0.04 & 0.003 & $-3.1^{* * *}$ & -0.5 \\
& $(0.06)$ & $(0.04)$ & $(0.9)$ & $(0.5)$ \\
Foreigners & $0.7^{* *}$ & 0.3 & -9.5 & $-5.2^{* *}$ \\
& $(0.3)$ & $(0.2)$ & $(6.0)$ & $(2.2)$ \\
Churches & $0.001^{* * *}$ & $0.0007^{* * *}$ & $0.01^{* * *}$ & $0.010^{* * *}$ \\
& $(0.0002)$ & $(0.00008)$ & $(0.003)$ & $(0.001)$ \\
N & -1.9 & -0.5 & $-52.7^{* * *}$ & $-17.5^{* *}$ \\
& $(1.2)$ & $(0.7)$ & $(11.5)$ & $(8.8)$ \\
\hline
\end{tabular}

Notes: Dependent Variable is innovative capacity measured by engineers per 100,000 male workers and patents per 100 inhabitants. Pre-colonial population density measures the number of natives per square kilometer in 1492. South a dummy capturing Southern US states; slavery as tabulated from the 1860 Census as compiled in Nunn (2008). Rainfall captures total yearly rainfall in meters; Altitude measures the elevation of the capital city of the state in kilometers; Ruggedness of Terrain from Nunn \& Puga (2012); Rivers captures the distance between the near river and the county. Rivers taken from HydroSHEDS (USGS 2011). Temperature is a yearly average in degrees celsius; Dist. to Coast is distance between the coast and the county centroid. Population density is number of individuals per 100 square kilometers in 1880. Foreigners is born people per capita taken from the 1880 census and University of Virginia Historical Census Browser (UVCB). Churches per capita at the county level, taken from the 1860 census. Robust SE in parenthesis. ${ }^{*} p<0.1,{ }^{* *} p<0.05,{ }^{* * *} p<0.01$. 